\title{
I.S.Mu.L.T. Achilles tendon ruptures guidelines
}

\author{
Francesco Oliva ${ }^{1}$ \\ Clelia Rugiero ${ }^{2}$ \\ Alessio Giai Via ${ }^{15}$ \\ Matteo Baldassarri ${ }^{3}$ \\ Gabriele Bernardi ${ }^{1}$ \\ Carlo Biz 5 \\ Michela Bossa ${ }^{4}$ \\ Roberto Buda ${ }^{3}$ \\ Daniela Buonocore ${ }^{6}$ \\ Vito Chianca ${ }^{7}$ \\ Anna Collina ${ }^{8}$ \\ Angelo De Carli ${ }^{2}$ \\ Vincenzo De Luna ${ }^{1}$ \\ Imma Di Lanno ${ }^{8}$ \\ Luigi Di Lorenzo ${ }^{8}$ \\ Francesco Di Pietto ${ }^{10}$ \\ Maurizia Dossena ${ }^{6}$ \\ Ilaria Fantoni ${ }^{5}$ \\ Pasquale Farsetti ${ }^{1}$ \\ Milena Fini ${ }^{12}$ \\ Paolo Finotti ${ }^{13}$ \\ Alfonso Maria Forte ${ }^{14}$ \\ Calogero Foti ${ }^{4}$ \\ Antonio Frizziero ${ }^{13}$ \\ Edoardo Gaj ${ }^{2}$ \\ Carlotta Galeone ${ }^{6}$ \\ Jacopo Gamberini ${ }^{13}$ \\ Monica Gasparini ${ }^{1}$ \\ Bernardo Innocenti ${ }^{11}$ \\ Domenico Lupariello \\ Asmaa Mahmoud 4,16 \\ Emanuela Marsilio ${ }^{1}$ \\ Biagio Moretti ${ }^{17}$ \\ Simone Natali ${ }^{3}$ \\ Johnny Padulo ${ }^{18}$ \\ Leonardo Pellicciari 4,18 \\ Luca Perazzo 3 \\ Eleonora Piccirilli ${ }^{1}$ \\ Pietro Picerno 20 \\ Pietro Ruggieri 5 \\ Umberto Tarantino ${ }^{1}$ \\ Antonio Vadalà ${ }^{2}$ \\ Francesca Veronesi ${ }^{21}$ \\ Manuela Verri 6 \\ Mario Vetrano 22 \\ Maria Chiara Vulpiani22 \\ Marcello Zappia ${ }^{23}$ \\ Nicola Maffulli244
}

1 Department of Orthopaedics and Traumatology, University of Rome "Tor Vergata", Rome, Italy

2 Department of Orthopaedics and Traumatology, "Sapienza" University of Rome, Sant'Andrea Hospital, Rome, Italy

3 Department of Orthopaedics and Traumatology, Rizzoli Orthopaedic Institute, Bologna, Italy

4 Department of Physical and Rehabilitation Medicine, University of Rome "Tor Vergata", Rome, Italy

5 Orthopaedics Unit, Department of Surgical, Oncologic and Gastroenterological Sciences DiSCOG, University of Padua, Padua, Italy

6 Department of Biology and Biotechnology, University of Pavia, Pavia, Italy

7 Department of Advanced Biomedical Sciences, University of Naples "Federico II", Naples, Italy

8 Department of Diagnostic Imaging, Campolongo Hospital, Eboli (SA), Italy

9 Rehabilitation Unit, G. Rummo Hospital, Benevento, Italy

10 Department of Diagnostic Imaging, AORNA, Cardarelli Hospital, Naples, Italy

${ }^{11}$ BEAMS Department (Bio Electro and Mechanical Systems), École Polytechnique de Bruxelles, Université Libre de Bruxelles, Brussels, Belgium

12 Laboratory of Preclinical and Surgical Studies, Rizzoli Orthopaedic Institute, Bologna, Italy

${ }^{13}$ Department of Physical and Rehabilitation Medicine, University of Padua, Padua, Italy

${ }^{14}$ Center of Rehabilitation and Biomedical Research, Biomedical Research Center Gruppo Forte, Salerno, Italy

15 Department of Orthopaedics and Traumatology, Hip Surgery Center, IRCCS San Donato Hospital, San Donato Milanese, Milan, Italy

${ }^{16}$ Department of Physical Medicine, Rheumatology and Rehabilitation, University of Cairo "Ain Shams, Cairo, Egypt

17 Department of Orthopaedics and Traumatology, Bari Hospital, Bari, Italy

18 Sport Sciences, University e-Campus, Novedrate, Italy; Tunisian Laboratory of Research for Sporty Performance Optimization, National Center of Medicine and Sport Sciences, Tunis, Tunisia

${ }^{19}$ Department Health Technical, USL Toscana Center, Empoly (FI), Italy

20 Telematics University e-Campus, Novedrate, Italy

${ }^{21}$ Rizzoli Orthopaedic Institute, Bologna, Italy

22 Department of Physical and Rehabilitation Medicine, "Sapienza" University of Rome, Sant'Andrea Hospital, Rome, Italy 
${ }^{23}$ Department of Medicine and Health Science, University of Molise, Campobasso, Italia; Varelli Institute, Naples, Italy

24 Department of Physical and Rehabilitation Medicine, San Giovanni di Dio e Ruggi d'Aragona Hospital, University of Salerno, Italy; University of London Queen Mary, Barts and the London School of Medicine and Dentistry, Sport Medicine Center, Mile End Hospital, London, UK

\section{Corresponding author:}

Francesco Oliva

Department of Orthopaedics and Traumatology,

University of Rome "Tor Vergata"

Viale Oxford 81

00133 Rome, Italy

E-mail: olivafrancesco@hotmail.com

\section{Summary}

This work provides easily accessible guidelines for the diagnosis, treatment and rehabilitation of Achilles tendon ruptures. These guidelines could be considered as recommendations for good clinical practice developed through a process of systematic review of the literature and expert opinion, to improve the quality of care for the individual patient and rationalize the use of resources. This work is divided into two sessions: 1) questions about hot topics; 2) answers to the questions following Evidence Based Medicine principles. Despite the frequency of the pathology and the high level of satisfaction achieved in treatment of Achilles tendon ruptures, a global consensus is lacking. In fact, there is not a uniform treatment and rehabilitation protocol used for Achilles tendon ruptures.

KEY WORDS: Achilles tendon ruptures, guidelines.

\section{Introduction}

Achilles tendon rupture is the most frequent tendon rupture in the human body ${ }^{1,2}$. In $85 \%$ of patients, the rupture is $2-7 \mathrm{~cm}$ proximal to its calcaneal insertion ${ }^{3}$. Acute ruptures of the Achilles tendon are most frequent in men ${ }^{4}, 30-40$ years old, in particular in weekend atlethes who play football, basketball, tennis and squash ${ }^{5}$. Chronic ruptures are defined as an untreated tendon rupture persisting more than 4 weeks ${ }^{3}$. The incidence changes in the different countries.

Re-rupture of the Achilles tendon is failure of its treatment $^{6}$, conservative $(12 \%)$ or surgical $(4 \%)^{7}$.

The etiology of the Achilles tendon rupture is multifactorial, including intrinsic and extrinsic factors, but the specific role and weight of each of these factors remains unclear (Tab. I).

\section{Methodology}

These guidelines are recommendations developed through a process of systematic review of the literature and expert opinion. The recommendations are based on the scientific evidence and clinical experience and can be used to improve the quality of care for individual patients.

The Authors were divided into four groups:

- Coordinator: conceived and organized the work with the group of experts.

- Overseeing group: controlled the development of the work and discussed the recommendations.

- Group of experts: individually received a question and developed the topic according to the rules of Evidence Based Medicine (EBM), when it was possible.

- Group of preparation and evaluation of literature: drew up the text and assisted the group of experts in evaluating the literature.

\section{Methods and criteria study selection}

For the research were consulted the following databases:

- PubMed;

- Embase;

- Web of Science;

- CINAHL;

- Scopus;

- Google Scholar;

- Cochrane Library.

Using the Preferred Reporting Items for Systematic Reviews and Meta-Analyses (PRISMA) guidelines, randomized controlled trials (RTCs) and systematic reviews were included; to follow if missing the first two, the other levels of evidence. Date of publications: 1987-November 2017.

\section{Level of evidence}

De Vries JG, Berlet GC. Understanding levels of evidence for scientific communication. Foot and Ankle Spec. 2010;3(4):205-9 (Tab. II).

\section{Question n. 1: Animal models}

The study of the animal models is consequent to the necessity of regenerate the tendon, identify optimal surgical techniques and rehabilitative protocol, accelerate return to work and return to sport.

The main animal models for Achilles tendon studies are mouse, rat and rabbit. The choice of animal model should be based on the type of study: rupture, tendinopathy, healing physiopathology.

Key points

- Animal models allow to study molecular and cellu- 
Table I. Extrinsic and intrinsic factors involved in the etiology of Achilles tendon rupture.

\begin{tabular}{|c|c|c|}
\hline Theory & Author & Year \\
\hline \multicolumn{3}{|c|}{ Extrinsic factors } \\
\hline \multirow[t]{3}{*}{ Mechanical factors } & Hunt KJ, et al. ${ }^{8}$ & 2014 \\
\hline & Józsa L, et al. ${ }^{9}$ & 1989 \\
\hline & Kannus $\mathrm{P}$, et al. ${ }^{10}$ & 1997 \\
\hline \multirow[t]{3}{*}{ Drugs } & Laseter JT, et al. ${ }^{11}$ & 1991 \\
\hline & Khaliq Y, et al. ${ }^{12}$ & 2003 \\
\hline & Parmar C, et al. ${ }^{13}$ & 2007 \\
\hline \multirow[t]{2}{*}{ Footwear, ground and type of training } & Wertz J, et al. ${ }^{14}$ & 2012 \\
\hline & Intrinsic factors & \\
\hline \multirow[t]{2}{*}{ Age } & Magnusson SP, et al. ${ }^{15}$ & 2002 \\
\hline & McCarthy MM, et al. ${ }^{16}$ & 2014 \\
\hline \multirow[t]{6}{*}{ Gender } & Claessen FMAP, et al. ${ }^{17}$ & 2014 \\
\hline & Hunt KJ, et al. ${ }^{8}$ & 2014 \\
\hline & Smith FB, et al. ${ }^{18}$ & 2002 \\
\hline & Frizziero $A$, et al. ${ }^{19}$ & 2014 \\
\hline & Lemoine $\mathrm{JK}$, et al. ${ }^{20}$ & 2009 \\
\hline & Cook JL, et al. ${ }^{21}$ & 2000 \\
\hline \multirow[t]{2}{*}{ Genetic factors (group $A B O$ ) } & Józsa L, et al. ${ }^{22}$ & 1989 \\
\hline & Kujala UM, et al.23 & 1992 \\
\hline Hormonal factors & Oliva F, et al. ${ }^{24}$ & 2016 \\
\hline Obesity & Battery L, et al. ${ }^{25}$ & 2011 \\
\hline Hypercholesterolemia & Hast MW, et al. ${ }^{26}$ & 2014 \\
\hline
\end{tabular}

lar characteristics and healing physiopathology through quantitative and qualitative analysis, not possible on human.

- Because of the heterogeneity of models and of studies, it is not possible to establish the best suture technique, the best suture material and whether adjuvant therapies ameliorate tendon healing after suture.

- Most animal models do not mimic rupture, but are simple transition models, and are therefore not relevant to the matter at hand.

Level of recommendation: $D$.

KEY WORDS: Achilles tendon, clinical trials, animal models, surgery, surgical sutures, tendon sutures.

\section{Question n. 2: Clinical diagnosis}

The clinical diagnosis is based on history (sudden and severe pain, audible snap), clinical exam in action (swelling, ecchymosis, tendon discontinuity) and clinical tests. The main clinical tests used are: Calf squeeze sign (Simmond-Thompson test), Single leg heel rise test, Matles test, Copeland test, O'Brien test.

Key points

- Signs and clinical tests recommended are:

- tendon discontinuity;

- calf squeeze sign;

- simmond triad (Matles test, Calf squeeze test, palpable gap).

Level of recommendation: $C$.

KEY WORDS: clinical test, physical examination, diagnosis, Achilles tendon rupture.

\section{Question n. 3: Ultrasound diagnosis}

Ultrasound is used to identify or to confirm Achilles tendon ruptures (both partial and total) and to identify Achilles tendon alterations. Ultrasound is able to identity silent mechanical and structural tendon 
Table II. Level of evidence and criteria for analysis.

\begin{tabular}{|c|c|}
\hline Level of evidence & Criteria for analysis and inclusion \\
\hline I & $\begin{array}{l}\text { Meta-analyzes and systematic reviews of randomized controlled trials } \\
\text { (RCTs) of high quality, or RCTs with minimum or low risk of bias. } \\
\text { Systematic reviews of high quality relative to cohort studies or case- } \\
\text { control. }\end{array}$ \\
\hline II & $\begin{array}{l}\text { Cohort studies or randomized case-control high quality, with minimal risk } \\
\text { of confounding or bias and with high or discrete probability of causation. }\end{array}$ \\
\hline III & $\begin{array}{l}\text { Case-control studies and retrospective comparison of well-conducted with } \\
\text { reasonable probability of causation. }\end{array}$ \\
\hline IV & Non-analytic studies as case series or individual cases \\
\hline \multicolumn{2}{|c|}{ Level of recommendation } \\
\hline A & $\begin{array}{l}\text { Supported by at least two studies of level lb or from a review } \\
\text { level la (" It was shown") }\end{array}$ \\
\hline $\mathrm{B}$ & $\begin{array}{l}\text { Supported by at least two independent studies of level II or } \\
\text { extrapolations from studies of level I ("it is possible") }\end{array}$ \\
\hline $\mathrm{C}$ & $\begin{array}{l}\text { Not supported by adequate studies of level I or II } \\
\text { ("indications") }\end{array}$ \\
\hline $\mathrm{D}$ & Indications of experts ("there is no evidence") \\
\hline
\end{tabular}

changes which led to rupture. Ultrasound is also used to identify complications after rupture (deep venous thrombosis) and to prevent complications after surgery (identifying sural nerve). It is necessary focused on: patient position, probe position, acoustic window utilized.

Key points

- Ultrasound is useful to diagnose Achilles tendon ruptures, but also to study Achilles tendon characteristics (length, biomechanics, degenerative features) and results after surgery.

Level of recommendation: $C$.

- Ultrasound is useful to guide to the best choice of treatment.

Level of recommendation: $C$.

- Ultrasound allows dynamic study. Dynamic study is more sensible than static study to recognize Achilles tendon diseases.

Level of recommendation: $B$.

- Ultrasound is helpful to recognized degenerative changes in Achilles tendon of asymptomatic athletes and to identify athletes with higher risk of Achilles tendon rupture.

Level of recommendation: $C$.
KEY WORDS: Achilles tendon, tear, injury, rupture, ultrasonography, ultrasound, sonography, sonoelastograhy.

\section{Question n. 4: Magnetic resonance diagnosis}

Preoperative magnetic resonance (MR) imaging is useful to distinguish partial from complete ruptures and to assess the site and the extent of the tear.

In acute ruptures, the tendon gap demonstrates intermediate signal intensity on T1-weighted images and high signal intensity on T2-weighted images. These findings are consistent with oedema and haemorrhage. In chronic ruptures, scar or fat may replace the tendon.

\section{Key points}

- MR is a valid alternative or complementary diagnostic technique.

- MR is recommended to identify or confirm Achilles tendon ruptures and to distinguish acute or chronic ruptures and partial or complete ruptures.

\section{Level of recommendation: $C$.}

KEY WORDS: Achilles tendon, rupture, tear, diagnosis, magnetic resonance, imagine. 


\section{Question n. 5: Conservative treatment}

The aim of both conservative and surgical treatment is restoring tendon length and tension to optimize force and function. In the last 10 years, the use of conservative treatment has increased in Europe. Modern rehabilitative protocols after conservative treatment are based on early weight bearing concession and early mobilization. However, it is not possible to establish which is the better treatment because of lack of high quality clinically applicable randomized studies.

Key points

- The choice between surgery and conservative treatment should be based on individual factors (age, comorbidities, functional necessity, physical activity, patient preference).

Level of recommendation: $A$.

- Conservative treatment is recommended if adequate functional rehabilitation is permitted (early mobilization and weight-bearing).

Level of recommendation: $B$.

- PRP infiltrations and rehabilitation after conservative treatment do not add benefits.

Level of recommendation: $C$

KEY WORDS: Achilles tendon, rupture, conservative, non surgical, non operative, rehabilitation.

\section{Question n. 6: Sutures and materials}

The suture must restore tendon continuity and resistance, allowing tendon glide and preventing adherences. In addition, the aim of suture is to support mechanical load during rehabilitation, preventing complications and recurrences.

There is lack of randomized clinical trials comparing the different types of sutures and the various techniques. Some studies are discordant on the recommendation of the most adequate technique.

Key points

- The use of absorbable sutures (Vycril, Polydioxanone) is safe because of strength and because of low rate of complications (granuloma, infections).

Level of recommendation: $B$.

- The choice of the suture technique (es. Bunnell, Kessler, Dresden, Krackow) depends on the experience and on the preference of the surgeon, because of lack of adequate studies.

Level of recommendation: $A$.

KEY WORDS: suture, material, Achilles tendon, repair, technique, tendon rupture.

\section{Question n. 7: Use of autologous derived}

The use of platelet-rich plasma (PRP) is started to aid tendon healing. PRP is rich of platelets and of their products such as vascular endothelial growth factor (VEGF), insulin-like growth factor (IGF), fibroblast growth factor (FGF), platelet-derived growth factor (PDGF), transforming growth factor beta (TGFb) and epidermal growth (EGF). These agents aid regeneration and tissue healing. The biological action of PRP is clear but it is unknow the best application protocol. There is no consensus in literature above the use of PRP in the Achilles tendon ruptures. The existing studies use different protocols, different kinds of $\mathrm{PRP}$, different surgical techniques and different rehabilitation protocols.

\section{Key points}

- PRP regenerative capacity is demonstrated.

- Which is the best type of PRP? PRP or PRF (platelet-rich fibrin)? Which is the best application protocol? Is it necessary to associate surgery? Which is the best surgery technique to associate? Which is the best rehabilitation protocol?

- High level of evidence studies are necessary. Level of recommendation: $A$.

KEY WORDS: Achilles tendon, Achilles tendon rupture, mesenchymal stem cells, MSC, PRP, platelet rich plasma, platelet gel, platelet derived growth factors, platelet concentrate, PRGF, platelet lysate, platelet rich fibrin, platelet rich membrane.

\section{Question n. 8: Open surgery}

The open surgical technique allows to directly see the tendon stumps but it mostly damages paratenon and tendon vascularization. The open technique requires less days of hospitalization compared with both conservative treatment and mini-open surgery. Different suture configurations can be utilized in open technique; the most frequently used are Bunnel, Kessler and Krackow. There are contrasting results on ROM, tropism, return to work, and to sport.

It is impossible to define the gold standard treatment of Achilles tendon acute ruptures and the better open suture technique because of lack of high level literature.

\section{Key points}

- There are no differences in clinical results after open or percutaneous surgery.

- Open surgery reduces the risk of re-ruptures.

- Open tenorrhaphy requires a longer surgery time and leads to a major rate of complications during wound healing.

- Open surgery is associated with a greater rate of complications, especially infections.

- The treatment choice should be individualised.

Level of recommendation: $B$.

KEY WORDS: Achilles tendon acute rupture, open tenorrhaphy, recurrence, complications.

\section{Question n. 9: Minimally invasive surgery}

The complications of the open treatment (infections, adherences, paresthesia, incision delayed healing) 
led to development of mini-invasive and percutaneous techniques. The main mini-invasive techniques studied are mini-open techniques, mini-open Dresden technique, mini-open Kakiuchi technique, Achillon device. The results are satisfactory (rate of complications, return to previous activities, objective and subjective questionnaires, imaging).

The literature does not offer high level studies. Adequate studies are necessary.

\section{Key points}

- Mini-invasive surgery techniques, used to treat the acute subcutaneous Achilles tendon ruptures, lead to optimal results and clinical recovery rate is at least $85 \%$.

- Absorbable sutures and the post-surgery weightbearing reduce the risk of complications.

- The use of PRP in the acute ruptures does not significantly ameliorate clinical and functional outcomes.

Level of recommendation: $C$.

KEY WORDS: Achilles tendon, rupture, mini-open, repair.

\section{Question n. 10: Percutaneous surgery}

Percutaneous techniques consist in no exposition of tendon stumps with intact skin. In this way, the two stumps are approached but not sutured. The first percutaneous technique was described by $\mathrm{Ma}$ and Griffith (1977). Subsequently, many modifications were introduced and different instruments used.

Key points

- Percutaneous surgery reduces surgery time and wound complications.

Level of recommendation: $A$.

- There are no statistically significant difference in clinical outcome between percutaneous and open surgery.

Level of recommendation: $A$.

- Earlier return to daily activities and to sport.

Level of recommendation: $C$.

- Higher rate of re-ruptures.

Level of recommendation: $C$.

- Percutaneous technique leads to a higher rate of sural nerve's lesions than open surgery.

Level of recommendation: $A$

- Lower rate of infective complications.

Level of recommendation: $C$.

KEY WORDS: Achilles tendon, tendon rupture, Achilles tendon repair, tendon suture, open repair, percutaneous suture.

Question n. 11: Tendon transfers for chronic tears Surgery treatment is necessary for the chronic Achilles tendon ruptures because of the retraction of tendon stumps. Tendon transfers are used for the treatment of inveterate Achilles tendon ruptures.
There are different tendon transfer techniques: autograft, allograft, xenograft (based on the source of donor) and flexor hallucis longus, peroneus brevis, gastrocnemius-soleus, fascia lata, semitendinosus, gracilis (based on the donor site). The results are good but randomized controlled clinical trials are necessary.

\section{Key points}

- Autograft transfer to treat chronic Achilles tendon ruptures with tendon loss $>50 \%$.

Level of recommendation: $A$.

- Allograft or xenograft transfer to treat inveterate Achilles tendon ruptures.

Level of recommendation: $D$.

- Lower rate of return to sport at the same level.

Level of recommendation: $A$.

- Higher post-surgery outcomes (AOFAS score, calf circumference) after tendon autograft.

Level of recommendation: $D$.

- Re-ruptures incidence after tendon autograft not statistically significant.

Level of recommendation: $D$.

- Infection (deep and superficial) incidence of the surgical wound not statistically significant.

Level of recommendation: $D$.

KEY WORDS: Achilles tendon and transfer, neglected Achilles tendon rupture, chronic Achilles tendon rupture, tendon transfer, Achilles tendon and flexor hallucis longus transfer, Achilles tendon and peroneus brevis tendon transfer.

\section{Question n. 12: Imaging post-surgery}

Imaging post-surgery allows to study the intrinsic characteristics of tendon fibers. Follow-up of an operated tendon is clinical. Post-surgery examination can include magnetic resonance imaging (MRI) or Ultrasound (US). Imaging examination may give important information regarding general morphology, tendon structure, grade of vascularisation and tissue mobility. In particular, US plays a crucial role in the followup of operated tendons because of the dynamic nature of this technique and the contribution of colourdoppler tool and MRI has shown to be a useful method to evaluate the healing process of surgically treated Achilles tendon. In addition, the use of elastosonography and diffusion tensor imaging (DTI) is increased. Elastosonography and DTI represent innovative and effective quantitative tools that might be able to provide microstructural abnormalities not appreciable using conventional radiological techniques. In last years, the use of DTI in musculoskeletal field keeps on growing in clinical practice. After surgical procedures the use of DTI may ascertain the microstructural properties and integrity restoration of the ruptured tendon during the healing process, even if DTI technique needs more studies on musculoskeletal structures. However, imaging post-surgery appearance of Achilles tendon repair is dependent on the surgical technique used. 
Key points

- Imaging post-surgery does not offer clinical and functional benefits.

- Use of DTI allows to have quantitative informations on tendon structure.

- Using Elastonography, healing tendons are shown to be softer than healthy tendons.

Level of recommendation: $D$.

KEY WORDS: imaging, follow-up, post-surgery, Achilles tendon, rupture, magnetic resonance, ultrasonography.

Question n. 13: Rehabilitation protocol after acute ruptures

Recently, the rehabilitation regimen after Achilles tendon ruptures has become more active. Immobilization and weight bearing prohibition for 6 weeks has been replaced by functional rehabilitation, characterized by partial or full weight bearing in the first 2 weeks after surgery, and active controlled mobilizations in the first few days after surgery. Functional rehabilitation can include early mobilization or early weight bearing, or both early mobilization and early weight bearing.

Key points

- Functional rehabilitation after surgery is safe and more advantageous than conventional immobilization.

Level of recommendation: $A$.

- There are no scientific evidences among the best rehabilitation protocol

Level of recommendation: $A$.

KEY WORDS: Achilles, ruptur ${ }^{\star}$, surg ${ }^{*}$, operat ${ }^{*}$, mobili $^{*}$, immobili*, cast*, weight bearing, rehab*, comparison.

Question n. 14: Rehabilitation protocol

after chronic ruptures

The rehabilitation protocol after chronic Achilles tendon ruptures proposed by these guidelines is as follows.

\section{WEEKS 1-4}

Cast/Boot $\left(30^{\circ}\right.$ plantar flexion), weight-bearing after 3 weeks, cautious mobilizations.

WEEKS 4-8

Complete weight-bearing with cast (5-6 weeks), progressive mobilizations.

WEEKS 8-12

Free deambulation, mobilizations against resistance, cyclette and swimming.

MONTHS 3-6

Sport specific exercises (closed chain), muscular strengthening.

$6^{\circ} \mathrm{MONTH}$

Jogging, running, jumping and eccentric exercises.

$8^{\circ}-9^{\circ} \mathrm{MONTH}$

Return to sport if possible.
Key points

- There are no scientific evidences among the best rehabilitation protocol.

Level of recommendation: $A$.

KEY WORDS: Achilles tendon, rehabilitation, program, chronic rupture.

\section{Question n. 15: Nutraceuticals}

The word nutraceutical derived from "nutrition + pharmaceutical". Nutraceuticals are food supplements: Larginine-a-ketoglutarate, methylsulfonylmethane, type I collagen, bromelain, polyphenols, vitamins ( $C$, A, B6, E), minerals (selenium, zinc), essential fatty acids (omega- 3 , omega- 6 ). Nutraceuticals can help the normal functions of human body. They have different mechanisms of action: antinflammatory, analgesic, antioxidant, collagen synthesis promotion, immunomodulation, free radicals scavenging.

\section{Key points}

- There are only studies on animal models (studies on human are necessary).

- The use of nutraceuticals, in different combinations, can be helpful to tendon healing and to Achilles tendon rupture prevention, with or without the addition of other strategies.

Level of recommendation: $D$.

KEY WORDS: supplement ${ }^{*}$, nutraceutical ${ }^{*}$, phytochemicals, extract*, plant, herbal, herbals, glucosamine, glycosaminoglycans, mucopolysaccharides, mucopolisaccharides, glycosaminoglycan polysulphate, glycosaminoglycan polysulfate, chondroitin sulphate, chondroitin sulfate, vitamin C, ascorbate, ascorbic acid, type I collagen, arginine, curcumin, boswellic acid, Boswellia, methylsulfonylmethane, bromelain, tendon*, tendinopathy, tendonitis, Achilles, peritendinitis, tendinitis, tendinosis.

\section{Question n. 16: Return to sport}

Achilles tendon rupture is frequent during sport activities, only $50 \%$ of patients return to sport after 1 year. Return to sport is on average 6 months after rupture. 4 of 5 patients return to play after Achilles tendon rupture. Different methods to evaluate function are utilized: AOFAS (American Orthopaedic Foot and Ankle Society Ankle-Hindfoot Score), ARPS (Achilles Rupture Performance Score), ATRS (Achilles Tendon Total Rupture Score), FAAM (Foot and Ankle Ability Measure), FAOS (Foot and Ankle Outcome Score-Ankle and Hindfoot), PAS (Physical Activity Scale), PER (Player Efficiency Rating). Therefore, it is not possible to compare the results of scientific researches.

\section{Key points}

- $80 \%$ of patients return to sport after Achilles tendon rupture.

- The literature is heterogeneous.

- Scientific evidence about return to play is needed to establish recovery time.

Level of recommendation: $D$. 
KEY WORDS: Achilles tendon and injury, Achilles tendon and rupture, recovery of function or performance outcome, athletic performance, return to play, return to sport, treatment outcome.

\section{Question n. 17: Outcome evaluation devices}

There are different types of outcome evaluation devices:

- non invasive laboratory techniques to estimate in vivo Achilles tendon force during deambulation;

- movement analysis through methodological and technological instruments: planar trajectories measurement of selected anatomic landmarks, constrain force returned by ground, inertial parameters and muscular geometries evaluation to calculate tendon force through reverse dynamic.

Key points

- AT force during terrestrial human locomotion can be estimated non-invasively through inverse dynamics by means of motion analysis techniques and musculoskeletal modeling.

- Such an approach, although clinical-friendly, presents several limitations due to the reliability of the collected experimental data and to the specificity of musculoskeletal models.

- State-of-the-art high-resolution imaging techniques are being used to record subject-specific musculoskeletal geometries to fit to motion data collected into the laboratory to improve the accuracy in estimating muscle force through inverse dynamics.

Level of recommendation: $D$.

KEY WORDS: joint kinematics, inverse dynamics, gait analysis, Achilles tendon force, musculoskeletal model.

\section{Question n. 18: Acute ruptures in the childhood}

Acute Achilles tendon ruptures in the childhood are rare. The rupture can be initially partial and can become total after few weeks because of a new trauma.

Key points

- In patients under 10 years old treatment can be conservative, with good results.

Level of recommendation: $C$.

- Chronic ruptures usually require open surgical treatment; if there is a wide gap, autografts can be used to bridge such gap.

Level of recommendation: $C$.

- Acute ruptures in skeletally mature patients can be treated both surgically (percutaneous technique) or conservative.

Level of recommendation: $C$.

KEY WORDS: pediatric Achilles tendon tear, pediatric Achilles tendon repair, pediatric Achilles tendon injury.
Answer n. 1: Animal models in Table III.

Answer n. 2: Clinical diagnosis in Table IV.

Answer n. 3: Ultrasound as diagnostic tool in Table V. Ultrasound as outcome measurement to establish treatment validity in Table VI.

\section{Answer n. 4: Magnetic resonance diagnosis}

Preoperative MR imaging is useful for distinguishing partial from complete rupture and assessing the site and extent of the tear ${ }^{93,94}$. At MR, partial tendon tears can be defined on MR images in the sagittal and axial planes demonstrating heterogeneous signal intensity and thickening of the tendon without complete interruption ${ }^{95}$. Longitudinal splits in chronic Achilles tendinopathy that are low to intermediate in signal intensity on long-TR/TE images may be seen in association with a superimposed acute partial tear. Linear or focal regions of increased signal and thickening of fibers without a tendinous gap are characteristic ${ }^{95}$.

Differentiation between partial tear and severe chronic Achilles tendinosis may be difficult apart from clinical history. In general, acute partial tears are often associated with subcutaneous edema, haemorrhage within the Kager fat pad and intratendinous haemorrhage at MR imaging, whereas chronic tendinosis does not usually demonstrate increased subcutaneous or intratendinous signal intensity on T2-weighted images ${ }^{96,97}$.

Complete Achilles tendon rupture manifests as discontinuity with fraying and retraction of the torn edges of the tendon. In acute rupture, the tendon gap demonstrates intermediate signal intensity on T1weighted images and high signal intensity on T2weighted images, findings that are consistent with edema and haemorrhage, whereas in chronic ruptures, scar or fat may replace the tendon ${ }^{97}$.

Key MRI findings include: a fluid-filled gap with or without interposed fat at the tear site in complete tendinous disruptions with discontinuity; fraying or corkscrewing of the tendon edges associated with proximal tendon retraction; in the absence of overlapping tendon edges, no tendon fibers can be seen at the tear site on axial images; tendon disruption with discontinuity and a wavy retracted tendon; associated haemorrhage or edema in intratendinous or peritendinous soft tissues on axial or sagittal images; effacement of Kager's triangle ${ }^{95}$

The main differential features between partial and complete tears include the following: partial tears demonstrate hyperintense signal with incomplete anterior-to-posterior or posterior-to-anterior extension on fat sat FSE PD images; complete tears demonstrate a hyperintense fluid-filled tendinous gap; tendon rupture usually occurs 2 to $6 \mathrm{~cm}$ superior to the os calcis; the size of the rupture varies, based on the degree of tendon retraction; ruptures demonstrate dif- 
Table III. Answer n. 1: Animal models.

\begin{tabular}{|c|c|c|c|c|}
\hline Authors & Year & Animal & Type of lesion & $\begin{array}{l}\text { Type of suture }+/ \text { - additional } \\
\text { techniques }\end{array}$ \\
\hline Dogan A, et al. ${ }^{27}$ & 2009 & $\begin{array}{l}36 \text { Sprague- } \\
\text { Dawley rats }\end{array}$ & Z-plasty & $\begin{array}{l}\text { Group 1: suture with 5-0 Ethibond; Group } \\
\text { 2: no suture }\end{array}$ \\
\hline $\begin{array}{l}\text { Lusardi DA, } \\
\text { Cain J E } 28\end{array}$ & 1994 & $\begin{array}{l}24 \text { New Zealand } \\
\text { rabbits }\end{array}$ & Longitudinal & $\begin{array}{l}\text { Group 1: 4-0 prolene "horizontal } \\
\text { mattress" suture; Group 2: fibrin sealant }\end{array}$ \\
\hline Jielile J, et al. ${ }^{29}$ & 2016 & $\begin{array}{l}135 \text { New Zealand } \\
\text { rabbits }\end{array}$ & $\begin{array}{l}\text { Unilateral tenotomy } \\
1.6 \mathrm{~cm} \text { by calcaneal } \\
\text { insertion }\end{array}$ & $\begin{array}{l}\text { Yurt-bone suture method Group 1: suture } \\
\text { + cast Group 2: suture + mobilization; } \\
\text { Group 3: control }\end{array}$ \\
\hline Aydın BK, et al. 30 & 2015 & 12 Wistar albino rats & $\begin{array}{l}\text { Cross sectional, } 5 \mathrm{~mm} \\
\text { by calcaneal insertion }\end{array}$ & $\begin{array}{l}\text { Modified Kessler technique with } 4 / 0 \\
\text { polypropylene Group 1: suture + topic } \\
\text { hemostatic agent Group 2: suture only }\end{array}$ \\
\hline Dabak TK, et al. ${ }^{31}$ & 2015 & 72 Wistar rats & $\begin{array}{l}\text { Cross sectional, } 5 \mathrm{~mm} \\
\text { by calcaneal insertion }\end{array}$ & $\begin{array}{l}\text { Modified Kessler technique with } 5 / 0 \\
\text { absorbable. Group 1: single } \\
\text { phospholipids injection post-surgery; } \\
\text { Group 2: multiple phospholipids injections } \\
\text { post-surgery; Group 3: hyaluronic acid } \\
\text { injection post-surgery } \\
\text { Control group: physiological solution } \\
\text { injection }\end{array}$ \\
\hline Aliodoust $\mathrm{M}$, et al. ${ }^{32}$ & 2014 & $\begin{array}{l}88 \text { Wistar rats with } \\
\text { and without diabetes - } \\
\text { streptozotocin induced }\end{array}$ & $\begin{array}{l}\text { Cross sectional, } 5 \mathrm{~mm} \\
\text { by calcaneal insertion }\end{array}$ & $\begin{array}{l}\text { Modified Kessler technique with } 4.0 \\
\text { nylon. Group 1: non diabetics, suture + } \\
\text { low-level laser therapy; Group 2: non } \\
\text { diabetics, suture; Group 3: diabetics+ } \\
\text { suture+ low-level laser therapy; Group 4: } \\
\text { diabetics + suture }\end{array}$ \\
\hline Gereli $A$, et al. ${ }^{33}$ & 2014 & 21 albino Wistar rats & $\begin{array}{l}\text { Cross sectional, } 5 \mathrm{~mm} \\
\text { by calcaneal insertion }\end{array}$ & $\begin{array}{l}\text { Modified Kessler technique with } 5 / 0 \\
\text { monofilament polypropylene. Group } 1 \text { : } \\
\text { suture }+0.01 \text { ml solution with organic } \\
\text { silicone; Group } 2: \text { suture }+0.01 \mathrm{ml} \\
\text { physiological solution }\end{array}$ \\
\hline Liang JJ, et al. ${ }^{34}$ & 2014 & $\begin{array}{l}120 \text { Sprague-Dawley } \\
\text { rats }\end{array}$ & $\begin{array}{l}\text { Cross sectional, in the } \\
\text { half tendon }\end{array}$ & $\begin{array}{l}\text { Modified Bunnell technique with 4-0; } \\
\text { Nylon. Group 1: suture + 0,2 ml } \\
\text { hyaluronic acid + tenocytes; Group 2: } \\
\text { suture + 0,2 ml hyaluronic acid; Group 3: } \\
\text { suture + physiological solution }\end{array}$ \\
\hline Selek O, et al. ${ }^{35}$ & 2014 & 40 albino Wistar rats & $\begin{array}{l}\text { Cross sectional, } 5 \mathrm{~mm} \\
\text { by calcaneal insertion }\end{array}$ & $\begin{array}{l}\text { Modified Kessler technique with 3-0 } \\
\text { Ethibond. Group 1: suture + } \\
\text { mesenchymal cells; Group 2: suture + } \\
\text { physiological solution }\end{array}$ \\
\hline Zeytin $\mathrm{K}$, et al. ${ }^{36}$ & 2014 & $\begin{array}{l}16 \text { albino diabetic } \\
\text { Sprague-Dawley rats }\end{array}$ & $\begin{array}{l}\text { Cross sectional, } 5 \mathrm{~mm} \\
\text { by calcaneal insertion }\end{array}$ & $\begin{array}{l}\text { Modified Kessler technique with 5-0 } \\
\text { monofilament polypropylene. Group 1: } \\
\text { suture + perichondral autologous graft } \\
\text { with suture 6-0 monofilament } \\
\text { polypropylene; Group 2: suture }\end{array}$ \\
\hline Hapa O, et al. ${ }^{37}$ & 2013 & $\begin{array}{l}32 \text { samples of bovine } \\
\text { Achilles tendon }\end{array}$ & $\begin{array}{l}\text { Cross sectional, } 5 \mathrm{~mm} \\
\text { by calcaneal insertion }\end{array}$ & $\begin{array}{l}\text { Krackow technique. Group 1: } 2 \text { sutures } \\
\text { with } 2 \text { sutures and } 2 \text { locked loops; Group } \\
\text { 2: } 2 \text { sutures with } 2 \text { strands and } 4 \text { locked } \\
\text { loops; Group } 3: 2 \text { sutures with } 2 \text { strands } \\
\text { and } 4 \text { locked loops; Group 4: } 2-0 \text { suture } \\
\text { with } 4 \text { strands and } 2 \text { loops }\end{array}$ \\
\hline
\end{tabular}


Continued from Table III

\begin{tabular}{|c|c|c|c|c|}
\hline Huri G, et al. ${ }^{38}$ & 2013 & $\begin{array}{l}27 \text { Merino Wether } \\
\text { sheeps }\end{array}$ & $\begin{array}{l}\text { Cross sectional, } 2 \mathrm{~cm} \\
\text { by calcaneal insertion }\end{array}$ & $\begin{array}{l}\text { Group 1: Modified Bunnell technique } \\
\text { Endobutton-assisted; Group 2: Krackow } \\
\text { technique; Group 3: native tendon }\end{array}$ \\
\hline $\begin{array}{l}\text { Nouruzian M, } \\
\text { et al. } 39\end{array}$ & 2013 & $\begin{array}{l}33 \text { diabetic } \\
\text { streptozotocin-induced } \\
\text { Wistar rats }\end{array}$ & $\begin{array}{l}\text { Cross sectional, } 5 \mathrm{~mm} \\
\text { by calcaneal insertion }\end{array}$ & $\begin{array}{l}\text { Kessler technique with } 4.0 \text { nylon. Group } \\
\text { 1: non diabetics + suture + low-level laser } \\
\text { therapy } 2.9 \mathrm{~J} / \mathrm{cm} \text {; Group } 2 \text { : non } \\
\text { diabetics+ suture + low-level laser } \\
\text { therapy } 11.5 \mathrm{~J} / \mathrm{cm} \text {; Group } 3 \text { : diabetics + } \\
\text { suture + low-level laser therapy } 2.9 \mathrm{~J} / \mathrm{cm} \text {; } \\
\text { Group } 4: \text { diabetics + suture+ low-level } \\
\text { laser therapy a } 11.5 \mathrm{~J} / \mathrm{cm}\end{array}$ \\
\hline Leek BT, et al. 40 & 2012 & $\begin{array}{l}84 \text { New Zealand } \\
\text { rabbits }\end{array}$ & $\begin{array}{l}\text { Cross sectional, } \\
\text { partial }(50 \%)\end{array}$ & $\begin{array}{l}\text { Krackow technique. Group 1: 0- } \\
\text { ultrabraide suture impregnated with } \\
\text { butyric acid; Group 2: non impregnated }\end{array}$ \\
\hline $\mathrm{Ni} \mathrm{T}$, et al. 41 & 2012 & $\begin{array}{l}64 \text { adult New Zealand } \\
\text { white rabbits }\end{array}$ & $\begin{array}{l}\text { Cross sectional, } 1-2 \\
\text { cm by calcaneal } \\
\text { insertion }\end{array}$ & $\begin{array}{l}\text { Kessler technique. Group 1: } 5-0 \text { vicryl } \\
\text { coated }+ \text { epitendinous suture; Gruppo } 2 \text { : } \\
5-0 \text { vicryl }+1 \mathrm{~cm} \text { by section electrospun } \\
\text { silk (ES) bounded to tendinous surface }+ \\
\text { lambda } 532 \mathrm{~nm} \text { and } 0.3 \mathrm{~W} / \mathrm{cm}^{2} \text { irradiated } \\
\text { for } 6 \text { minutes }\end{array}$ \\
\hline Ishiyama N, et al. ${ }^{42}$ & 2011 & 18 Wistar rats & $\begin{array}{l}\text { Cross sectional, } 5 \mathrm{~mm} \\
\text { by calcaneal insertion }\end{array}$ & $\begin{array}{l}\text { Kessler technique with 6-0 braided } \\
\text { polyestere + cast. Group 1: suture + } \\
\text { injected 2- metha cryloyloxyethyl } \\
\text { phosphorylcholine (MPC) polymer 2,5\%; } \\
\text { Group 2: suture + injected 2-metha } \\
\text { cryloyloxyethyl phosphorylcholine (MPC) } \\
\text { polymer 5.0; Group 3: suture + } \\
\text { physiological solution }\end{array}$ \\
\hline Ishiyama N, et al. 43 & 2010 & 12 Wistar rats & $\begin{array}{l}\text { Cross sectional, } 5 \mathrm{~mm} \\
\text { by calcaneal insertion }\end{array}$ & $\begin{array}{l}\text { Kessler technique with 6-0 braided } \\
\text { polyestere + cast. Group 1: suture + } \\
\text { injected 2-metha cryloyloxyethyl } \\
\text { phosphorylcholine (MPC) polymer 2,5\%; } \\
\text { Group 2: suture + injected 2- metha } \\
\text { cryloyloxyethyl phosphorylcholine (MPC) } \\
\text { polymer 5.0; Group 3: suture + } \\
\text { physiological solution }\end{array}$ \\
\hline Lyras DN, et al. ${ }^{44}$ & 2011 & $\begin{array}{l}48 \text { New Zealand } \\
\text { white rabbits }\end{array}$ & $\begin{array}{l}\text { Cross sectional, } 2 \mathrm{~cm} \\
\text { by calcaneal insertion }\end{array}$ & $\begin{array}{l}\text { Paratenon with continuous suture } 4-0 \\
\text { nylon. Group1: suture }+ \text { injected } 0.5 \mathrm{ml} \text { of } \\
\text { PRP distal and proximal tendon } \\
\text { insertions; Group 2: suture }\end{array}$ \\
\hline Saygi B, et al. ${ }^{45}$ & 2008 & $\begin{array}{l}45 \text { Sprague-Dawley } \\
\text { rats }\end{array}$ & $\begin{array}{l}\text { Cross sectional, } 5 \mathrm{~mm} \\
\text { by calcaneal insertion }\end{array}$ & $\begin{array}{l}\text { Kessler technique } 3 / 0 \text { Ethibond. Group } 1 \text { : } \\
\text { suture; Group } 2 \text { : direct exposition to air }+ \\
\text { irrigation with } 3 \text { drops physiological } \\
\text { solution each } 5 \text { minutes for } 60 \text { minutes + } \\
\text { suture; Group } 3: \text { exposition to air for } 60 \\
\text { minutes + suture }\end{array}$ \\
\hline Chong AK, et al. 46 & 2007 & $\begin{array}{l}57 \text { New Zealand } \\
\text { white rabbits }\end{array}$ & $\begin{array}{l}\text { Cross sectional, in the } \\
\text { half tendon }\end{array}$ & $\begin{array}{l}\text { Modified Kessler technique with prolene } \\
\text { 4-0. Group 1: suture + mesenchymal } \\
\text { bone marrow cells in a fibrin carrier; } \\
\text { Group 2: suture + fibrin carrier }\end{array}$ \\
\hline Gilbert TW, et al. ${ }^{47}$ & 2007 & 12 mongrel dogs & $\begin{array}{l}\text { Segmental excision, } \\
1.5 \mathrm{~cm} \text { in the half } \\
\text { tendon }\end{array}$ & $\begin{array}{l}\text { Graft marked with carbonio } 142 \times 3 \mathrm{~cm} \\
\text { extracellular matrix of intestinal } \\
\text { submucosa and suture } 4-0 \text { prolene }\end{array}$ \\
\hline
\end{tabular}




\section{F. Oliva et al.}

Continued from Table III

\begin{tabular}{|c|c|c|c|c|}
\hline Duygulu F, et al. 48 & 2006 & $\begin{array}{l}22 \text { New Zealand } \\
\text { rabbits }\end{array}$ & $\begin{array}{l}\text { Cross sectional, in the } \\
\text { half tendon }\end{array}$ & $\begin{array}{l}\text { Modified Kessler technique with 4/0 PDS } \\
+ \text { cast. Group 1: suture + nicotine } \\
\text { subcutaneous injection } 3 \mathrm{mg} / \mathrm{kg} / \mathrm{die} \text {; } \\
\text { Group 2: suture + physiological solution } \\
\text { infusion }\end{array}$ \\
\hline Strauch B, et al. ${ }^{49}$ & 2006 & $\begin{array}{l}40 \text { Sprague-Dawley } \\
\text { rats }\end{array}$ & Cross sectional & $\begin{array}{l}\text { Modified Kessler technique with 6-0 } \\
\text { nylon. Active group: suture + PMF } \\
\text { (pulsed-magnetic-field) } 2 \text { sessions ( } 30 \\
\text { minutes/die) for } 3 \text { weeks; Control group: } \\
\text { suture }\end{array}$ \\
\hline Bolt $P$, et al. .50 & 2007 & $\begin{array}{l}90 \text { Sprague-Dawley } \\
\text { rats }\end{array}$ & $\begin{array}{l}\text { Cross sectional, } \\
\text { in the half tendon }\end{array}$ & $\begin{array}{l}\text { Horizontal mattress with 6-0 Ticron. } \\
\text { Group 1: suture + transfection with } \\
\text { adenovirus expressing green fluorescent } \\
\text { protein gene (AdGFP); Group 2: suture + } \\
\text { transfection with adenovirus expressing } \\
\text { humane BMP-14 gene and AdBMP-14; } \\
\text { Group 3: suture }\end{array}$ \\
\hline Zantop T, et al. ${ }^{51}$ & 2006 & $\begin{array}{l}40 \text { chimerical rats } \\
\text { expressing fluorescent } \\
\text { green protein in all } \\
\text { mesenchimal cells }\end{array}$ & $\begin{array}{l}\text { Step 1: placing 7-0 } \\
\text { prolene suture loops } 2 \\
\text { cm apart in the } \\
\text { midsubstance of the } \\
\text { tendon. Step 2: the } \\
\text { tendon was cut within } \\
\text { the suture loops to } \\
\text { hold the explanted } \\
\text { tendon in place. Step } \\
\text { 3: the sutures were } \\
\text { finally performer to } \\
\text { secure the autologous } \\
\text { tendon graft }\end{array}$ & $\begin{array}{l}\text { Two 7-0 Vicryl sutures were placed } \\
\text { proximal and distal in the Achilles tendon. } \\
\text { A single layer of lyophilized porcine small } \\
\text { intestinal sub mucosa (SIS) was secured } \\
\text { to the cut ends of the tendon with 7-0 } \\
\text { prolene suture. Finally, the graft and the } \\
\text { graft was hydrated with saline. } \\
\text { Group 1: SIS graft; Group 2: autologus } \\
\text { tendon repair }\end{array}$ \\
\hline Chan BP, et al. 52 & 2005 & $\begin{array}{l}48 \text { Sprague-Dawley } \\
\text { adult rats }\end{array}$ & $\begin{array}{l}\text { Cross sectional, } 6 \mathrm{~mm} \\
\text { by calcaneal insertion }\end{array}$ & $\begin{array}{l}\text { Modified Kessler technique }+ \text { cast }+ \\
\text { injected Rosa bengala (RB) solution } \\
(0.1 \%) \text { at the extremities lesions. Group } \\
\text { 1: suture; Group 2: laser Group 3: RB } \\
\text { only; Group 4: photochemical tissue } \\
\text { bonding (PTB) treatment (RB + laser) }\end{array}$ \\
\hline Kashiwagi K, et al. 53 & 2004 & 90 Wistar rats & $\begin{array}{l}\text { Cross sectional, } 5 \mathrm{~mm} \\
\text { by calcaneal insertion }\end{array}$ & $\begin{array}{l}\text { Tsuge technique with 5/0 nylon. Control } \\
\text { group: suture + local injection of } \\
\text { physiological solution; Group 1: suture + } \\
\text { local injection of TGF-beta1 } 10 \text { ng; Group } \\
\text { 2: suture + local injection of TGF-beta1 } \\
100 \text { ng }\end{array}$ \\
\hline Orhan Z, et al. ${ }^{54}$ & 2004 & 48 Wistar albino rats & Cross sectional & $\begin{array}{l}\text { Modified Kessler technique. Group 1: } \\
\text { suture + shock waves (ESWT) post- } \\
\text { surgery; Group } 2 \text { : suture Group } 3: \text { suture } \\
+50015 \mathrm{KV} \text { shock waves in } 2^{\text {nd }} \text { day post- } \\
\text { surgery }\end{array}$ \\
\hline $\begin{array}{l}\text { Kazimoğlu C, } \\
\text { et al. }{ }^{55}\end{array}$ & 2003 & $\begin{array}{l}75 \text { Sprague-Dawley } \\
\text { rats }\end{array}$ & $3 \mathrm{~cm}$ lesion & $\begin{array}{l}\text { Group 1: only cutaneous incision; Group } \\
\text { 2: lesion } 1 \mathrm{~cm} \text { by calcaneal insertion + } \\
\text { cast; Group 3: modified Kessler } \\
\text { technique; Group 4: plasty with } \\
\text { biodegradable film PCL (poly-e- } \\
\text { caprolactone); Group 5: lesion } 1 \mathrm{~cm} \text { distal } \\
\text { by half tendon }\end{array}$ \\
\hline
\end{tabular}

To be continued 
Continued from Table III

\begin{tabular}{|c|c|c|c|c|}
\hline Palmes D, et al. ${ }^{56}$ & 2002 & 114 Balh-C mice & $\begin{array}{l}\text { Cross sectional, } 5 \mathrm{~mm} \\
\text { by calcaneal insertion }\end{array}$ & $\begin{array}{l}\text { Modified Kirchmayr-Kessler technique. } \\
\text { Group 1: equine cast; Group 2: passive } \\
\text { mobilization; Group 3: controlateral } \\
\text { Achilles tendons }\end{array}$ \\
\hline Thermann $\mathrm{H}$, et al. ${ }^{57}$ & 2002 & 105 rabbits & $\begin{array}{l}5 \text { longitudinal lesion, } 1 \\
\text { cm by calcaneal } \\
\text { insertion }\end{array}$ & $\begin{array}{l}\text { Group 1: continuous fascia suture; } \\
\text { Group 2: suture with 5/0 plantar flexion; } \\
\text { Group 3: } 1 \mathrm{~mm} \text { of fibrin glue }\end{array}$ \\
\hline Rickert M, et al. ${ }^{58}$ & 2001 & $\begin{array}{l}80 \text { Sprague-Dawley } \\
\text { rats }\end{array}$ & $\begin{array}{l}\text { Cross sectional, } 5 \mathrm{~mm} \\
\text { by calcaneal insertion }\end{array}$ & $\begin{array}{l}\text { Suture with } 3 \text { points. Group 1: suture } \\
\text { impregnated with growth and } \\
\text { differentiation factor-5 (GDF-5); } \\
\text { Group 2: suture }\end{array}$ \\
\hline $\begin{array}{l}\text { Pneumaticos SG, } \\
\text { et al. } 59\end{array}$ & 2000 & $\begin{array}{l}24 \text { New Zealand } \\
\text { rabbits }\end{array}$ & $\begin{array}{l}\text { Cross sectional, } 1-1.5 \\
\text { cm by calcaneal } \\
\text { insertion }\end{array}$ & $\begin{array}{l}\text { Krackow technique }+ \text { immobilization at } \\
90^{\circ} \text { with Kirschner wire Group } 1: 35 \text { days } \\
\text { of immobilization; Group 2: } 14 \text { days }+ \\
\text { active mobilization }\end{array}$ \\
\hline Owoeye I, et al. ${ }^{60}$ & 1987 & $\begin{array}{l}60 \text { Sprangue-Dawley } \\
\text { rats }\end{array}$ & Cross sectional & $\begin{array}{l}\text { Suture with } 5-0 \text { black silk }+ \text { glue for } K \\
\text { wire fixation. Group } 1 \text { : suture }+ \text { anodic } \\
\text { electrical stimuli ( } 15 \text { minutes for } 2 \text { weeks } \\
75 \text { microA and } 10 / \text { sec frequency); Group } \\
\text { 2: suture + catodic electrical stimuli; } \\
\text { Control group: no suture, no electricity }\end{array}$ \\
\hline Petrou CG, et al. ${ }^{61}$ & 2009 & $\begin{array}{l}42 \text { New Zealand } \\
\text { white rabbits }\end{array}$ & $\begin{array}{l}\text { Tenotomy, } 3 \mathrm{~cm} \text { by } \\
\text { calcaneal insertion }\end{array}$ & $\begin{array}{l}\text { Absorbable epitenon suture. Group 1: } \\
\text { calcitonin } 21 \mathrm{IU} / \mathrm{kg} \text { intramuscularly; } \\
\text { Group 2: physiological solution }\end{array}$ \\
\hline Fukawa T, et al. 62 & 2015 & $\begin{array}{l}24 \text { New Zealand } \\
\text { white rabbits }\end{array}$ & $\begin{array}{l}\text { Cross sectional, } 2 \mathrm{~cm} \\
\text { by calcaneal insertion }\end{array}$ & $\begin{array}{l}\text { Paratenon suture with standard technique } \\
\text { 4-0 nylon. Group } 1: 1.0 \mathrm{ml} \text { di PRP } \\
\text { application; Group } 2: 1.0 \mathrm{ml} \text { physiological } \\
\text { solution application }\end{array}$ \\
\hline Adams SB, et al. 63 & 2014 & $\begin{array}{l}54 \text { Sprague } \\
\text { Dawley rats }\end{array}$ & $\begin{array}{l}2 \text { Cross sectional } \\
\text { lesions, } 3 \mathrm{~mm} \text { by } \\
\text { muscle-tendon origin } \\
\text { muscolo tendine with } \\
3 \mathrm{~mm} \text { segmental } \\
\text { tendon excision }\end{array}$ & $\begin{array}{l}\text { Suture type } 8 . \text { Group } 1 \text { : suture only; } \\
\text { Group 2: suture + mesenchymal cells } \\
\text { injection }\end{array}$ \\
\hline Irkören S, et al. ${ }^{64}$ & 2012 & $\begin{array}{l}8 \text { New Zealand } \\
\text { white rabbits }\end{array}$ & $\begin{array}{l}\text { Cross sectional, } 5 \mathrm{~mm} \\
\text { by calcaneal insertion }\end{array}$ & $\begin{array}{l}\text { Modified Kessler technique with } 5 / 0 \\
\text { monofilament polypropylene. Group } 1 \text { : } \\
\text { suture + perichondral autologous graft by } \\
\text { right ear and continuous suture with } 6-0 \\
\text { monofilament polypropylene; Group } 2 \text { : } \\
\text { suture only }\end{array}$ \\
\hline $\begin{array}{l}\text { Meimandi-Parizi A, } \\
\text { et al. } 65\end{array}$ & 2013 & $\begin{array}{l}75 \text { White New Zealand } \\
\text { rabbits }\end{array}$ & Longitudinal & $\begin{array}{l}\text { Kessler technique with monofilament } \\
\text { absorbable 4-0 polydioxanon. Group } 1 \text { : } \\
\text { suture + collagen implant; Group 2: } \\
\text { suture only }\end{array}$ \\
\hline Oryan A, et al. 66 & 2013 & $\begin{array}{l}40 \text { white New Zealand } \\
\text { rabbits }\end{array}$ & $\begin{array}{l}2 \text { Cross sectional } \\
\text { lesions, } 5 \mathrm{~mm} \text { by } \\
\text { muscle-tendon origin } \\
\text { with } 5 \mathrm{~mm} \text { segmental } \\
\text { tendon excision }\end{array}$ & $\begin{array}{l}\text { Kessler technique. Group 1: suture + } \\
\text { collagen 3-D structure between tendon } \\
\text { stumps; Group 2: suture only }\end{array}$ \\
\hline Godbout C, et al. ${ }^{67}$ & 2009 & $\begin{array}{l}12 \text { males } \\
\text { C57BL/6 mice }\end{array}$ & Cross sectional & $\begin{array}{l}\text { Technique type } 8 \text { with VICRYL 6-0. } \\
\text { Group 1: suture + suture impregnated } \\
\text { with antibodieswhich induce } \\
\text { thrombocytopenia; Group 2: suture + } \\
\text { placebo }\end{array}$ \\
\hline
\end{tabular}


Table IV. Answer n. 2: Clinical diagnosis.

\begin{tabular}{|c|c|c|c|c|}
\hline Sign/Test & Action & Significance & Sensitivity & Specificity \\
\hline $\begin{array}{l}\text { Tendon } \\
\text { discontinuity } 68-70\end{array}$ & $\begin{array}{l}\text { Palpation of the tendon } \\
\text { in prone position }\end{array}$ & Positive if palpable gap is felt & 0.73 & 0.89 \\
\hline $\begin{array}{l}\text { Calf squeeze } \\
\text { sign } 69-70 \\
\text { (Thompson's test) }\end{array}$ & $\begin{array}{l}\text { Compression of the } \\
\text { triceps muscle in a prone } \\
\text { patient }\end{array}$ & $\begin{array}{l}\text { Positive if the manoeuvre cannot } \\
\text { elicit foot plantarflexion }\end{array}$ & 0.96 & 0.93 \\
\hline Matles's test ${ }^{71-73}$ & $\begin{array}{l}\text { Active knee flexion } \\
\text { in the prone position }\end{array}$ & $\begin{array}{l}\text { Positive if knee flexion leads to } \\
\text { progressive foot dorsiflexion }\end{array}$ & 0.88 & 0.85 \\
\hline Simmonds triad 74,69 & $\begin{array}{l}\text { Association of tendon } \\
\text { discontinuity, } \\
\text { Thompson's test and } \\
\text { Matles test }\end{array}$ & Positive if all three signs are present & 1 & \\
\hline
\end{tabular}

fuse convexity of the anterior margin and enlarged tendon ends at the tear site ${ }^{97}$.

We point out, however, that even advanced imaging techniques should be interpreted in the light of clinical findings. In case of diagnostic doubts, the fallback position should be more accurate clinical examination, not just this imaging.

Answer n. 5: Conservative treatment in Tables VIIVIII.

\section{Answer n. 6: Sutures and materials in Table IX.}

Answer n. 7: Use of autologous derived blood products in Table $X$.

Answer n. 8: Open surgery in Table XI.

Answer n. 9: Minimally invasive surgery in Table XII.

Answer n. 10 : Percutaneous surgery in Table XIII.

\section{Answer n. 11: Tendon transfers in Table XIV.}

\section{Answer n. 12: Imaging post-surgery}

Despite follow-up of an operated tendon is primarily clinical, postoperative examination has been improved by the recent technological progress either on
MRI or on ultrasound that allow better representation of tendon structural specimens. Postoperative imaging appearance of Achilles tendon repair is dependent on the surgical technique used. Imaging examination allows to obtain information regarding: general morphology, tendon structure, grade of vascularity, tissue mobility.

\section{Ultrasound}

Ultrasound (US) can be used to follow-up operated tendons ${ }^{219}$ because of the dynamic nature of this technique and the contribution of colour-doppler tool220-221.

Both scans are essential for the correct examination of the treated area and for correct measurement of tendon's dimension. The operated tendon is thicker and wider than a normal ones; its mean thickness is about $10 \mathrm{~mm}$ (ranged from 7 to $16 \mathrm{~mm}$ ) whereas the average diameter of a healthy tendon is $5.4 \mathrm{~mm}$ (ranged from 4.0 to $7.9 \mathrm{~mm}$ ) 222 . This progressive increase in size occurs during the first 3-6 months after surgery and gradually decrease in thickness 1 year after surgery 223,224.

Fluid collections are suggestive of a poor prognosis if greater than $50 \%$ of the affected tendon, and extensive intratendinous calcifications should be considered pathological ${ }^{225}$. The contours of the tendon may be irregular with hypoechoic peritendinous area, which may persist for up to 3 months ${ }^{226}$, and small hypoechoic areas may surround the stitches into 6-24 months after surgical treatment 220,224 .

The microvascularity assessment with colour-doppler tool shows newer vessels with higher flow rates during the healing process ${ }^{227-228}$; the vascular response may indicate tendon healing with initial high flow vas- 


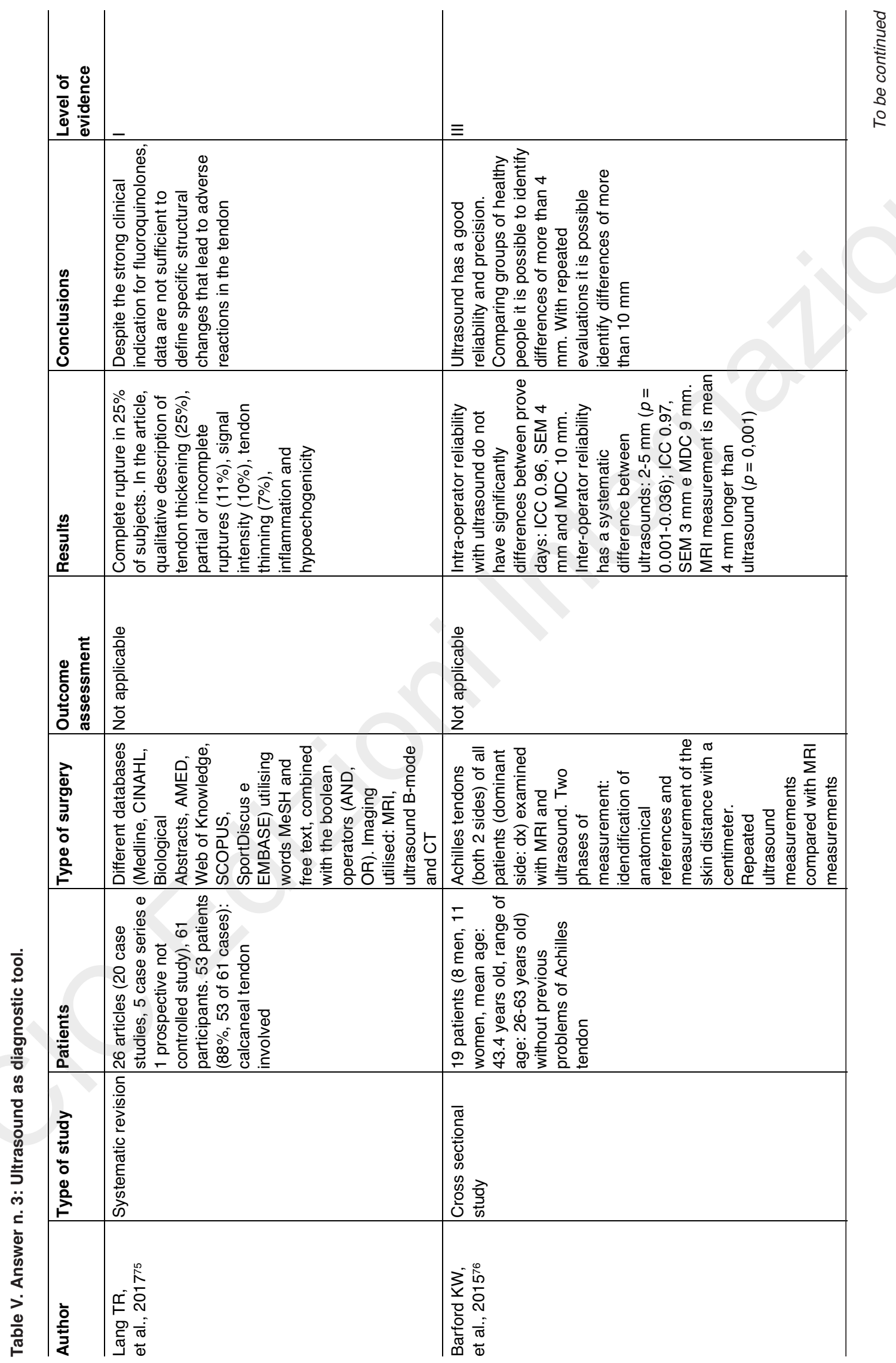




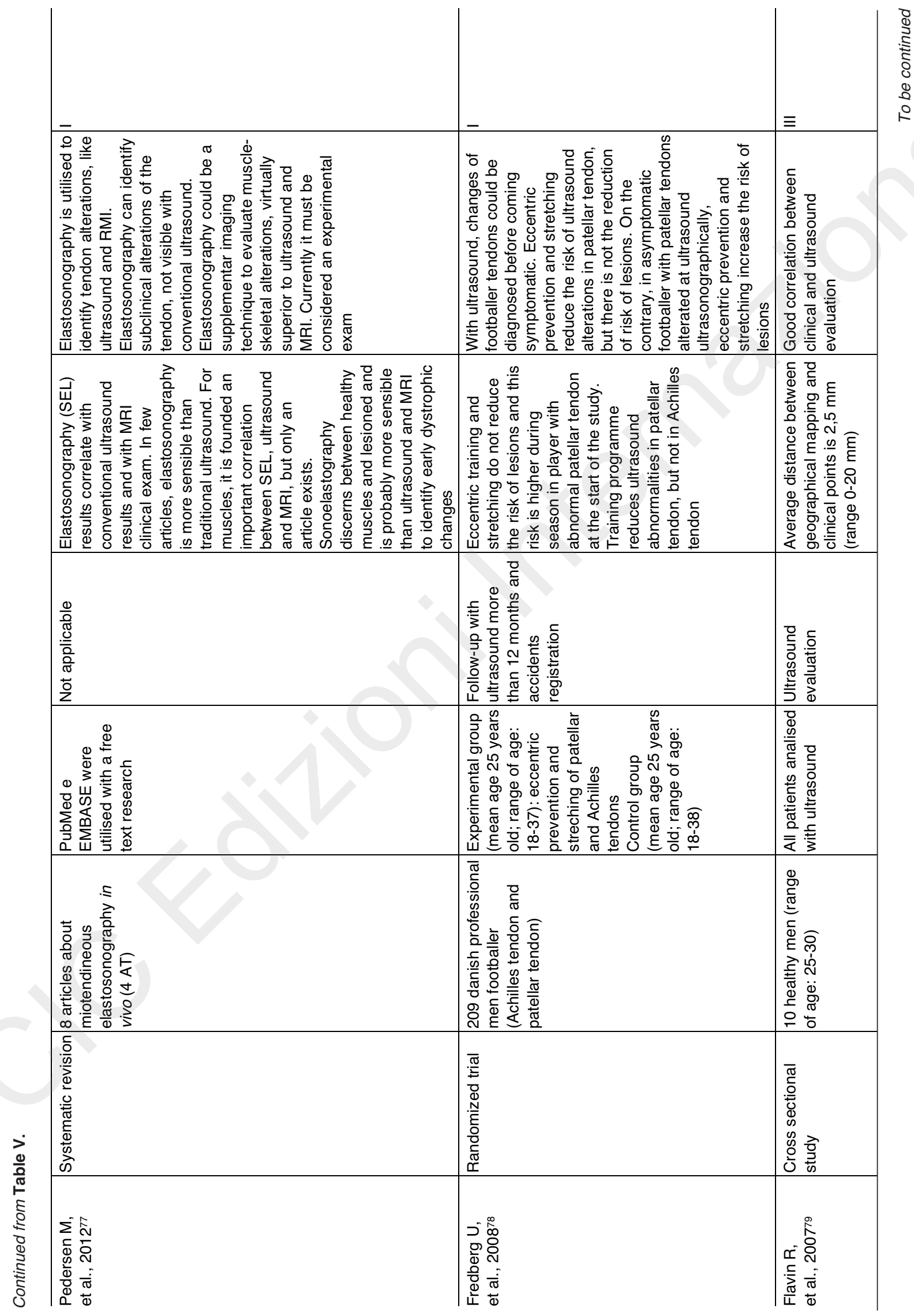




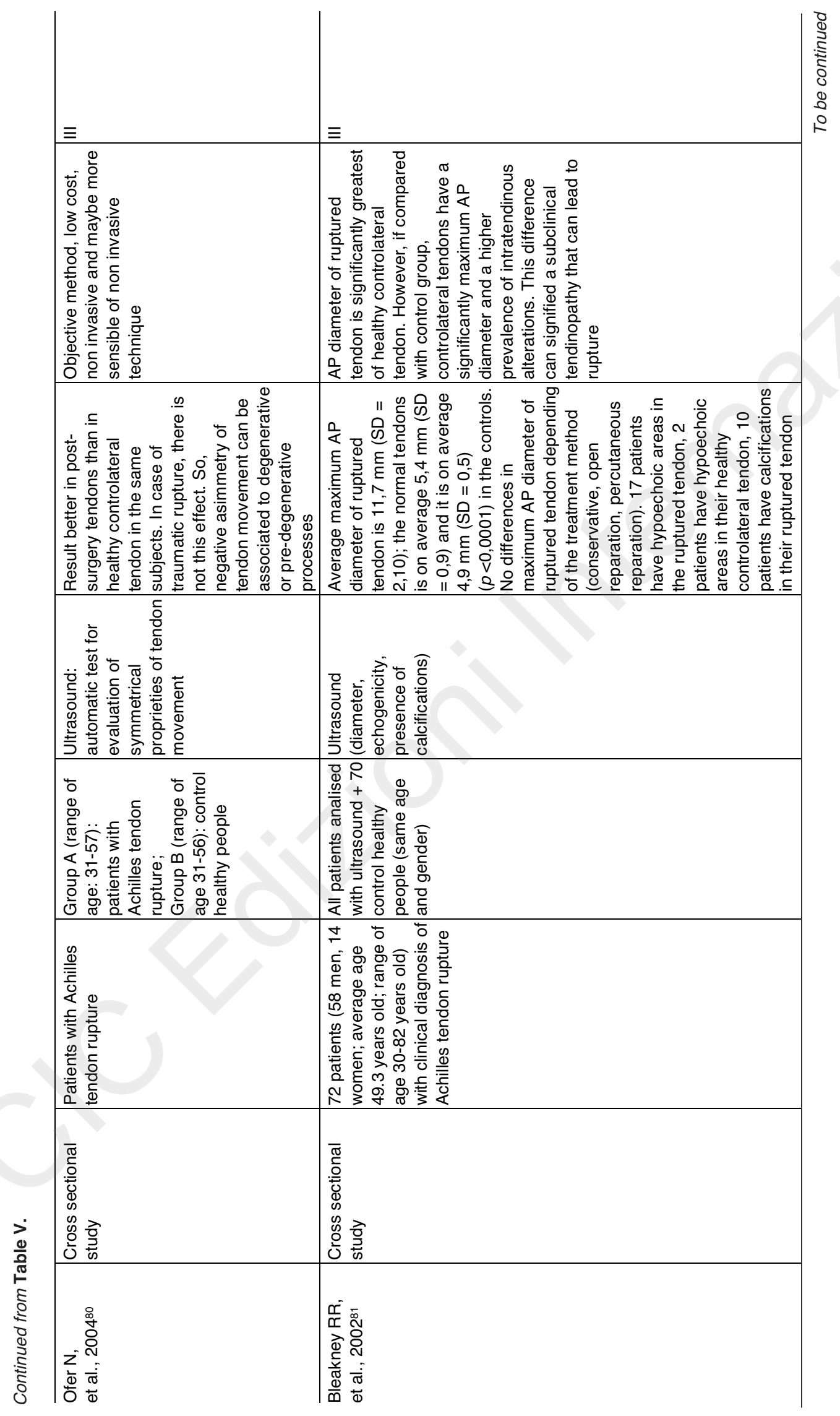


E

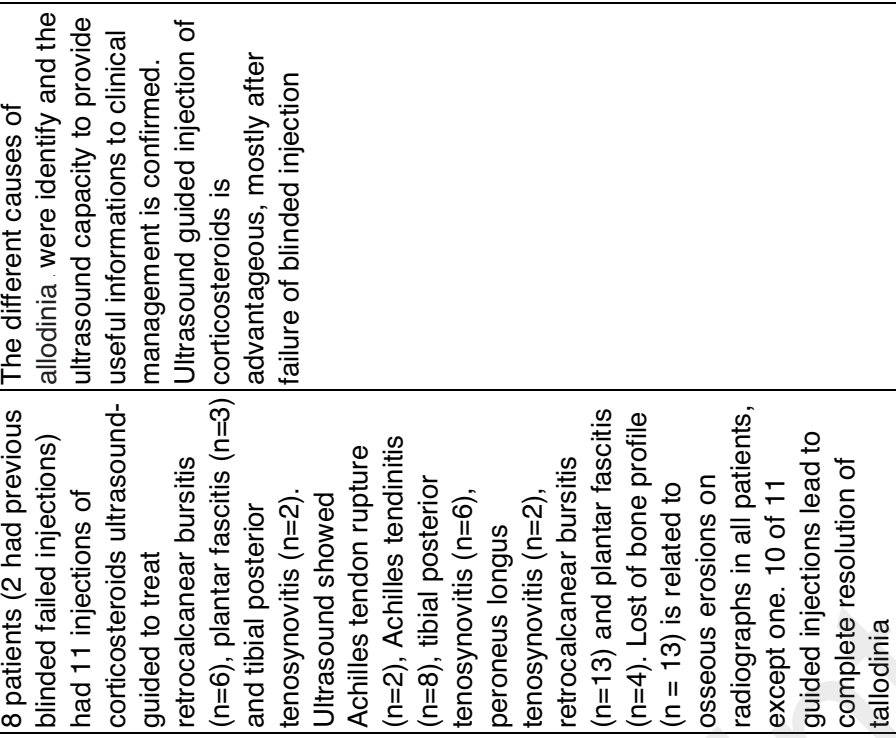

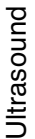

赵

की

垔

这売

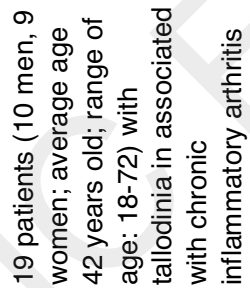

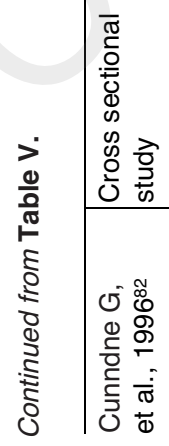




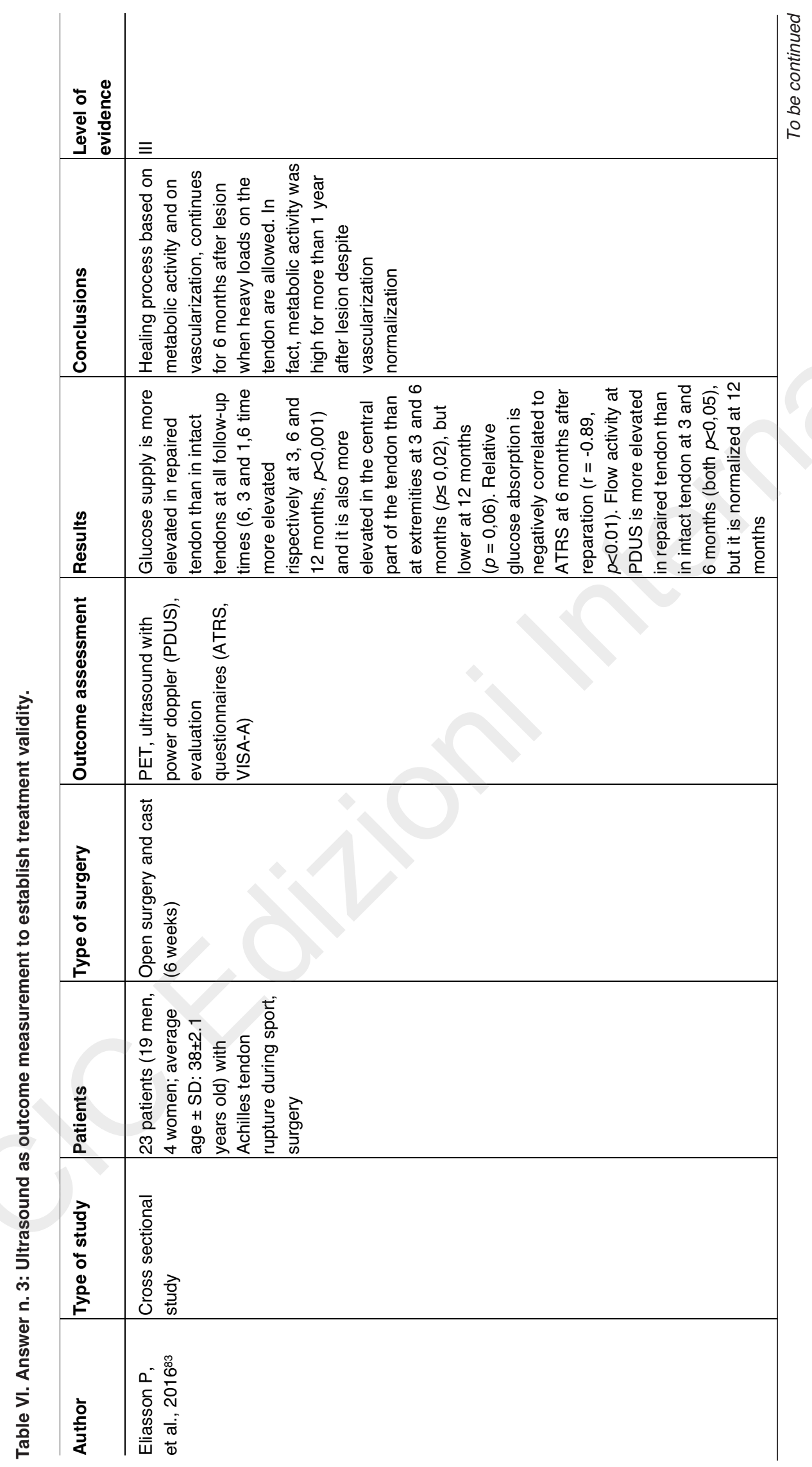




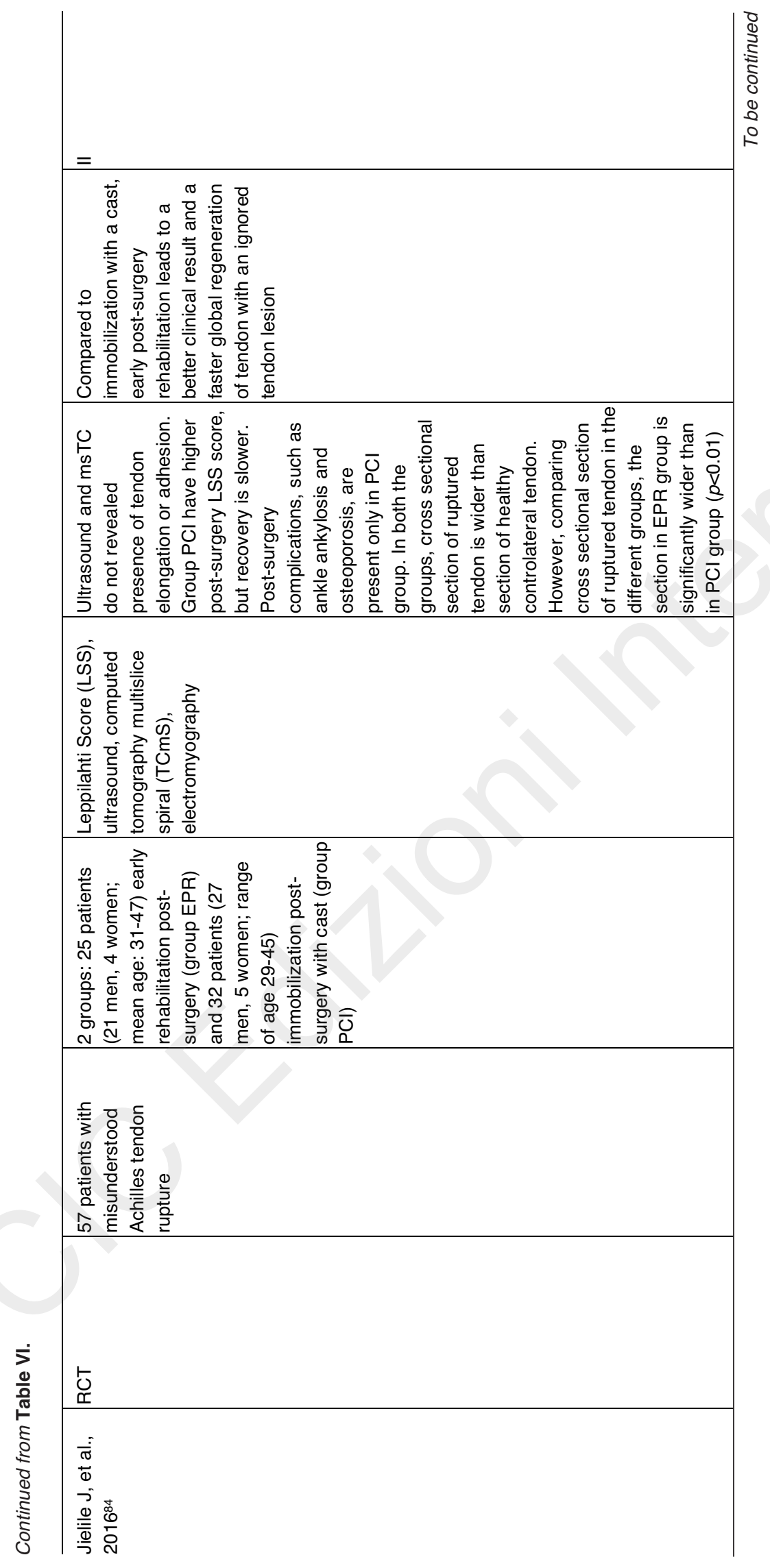




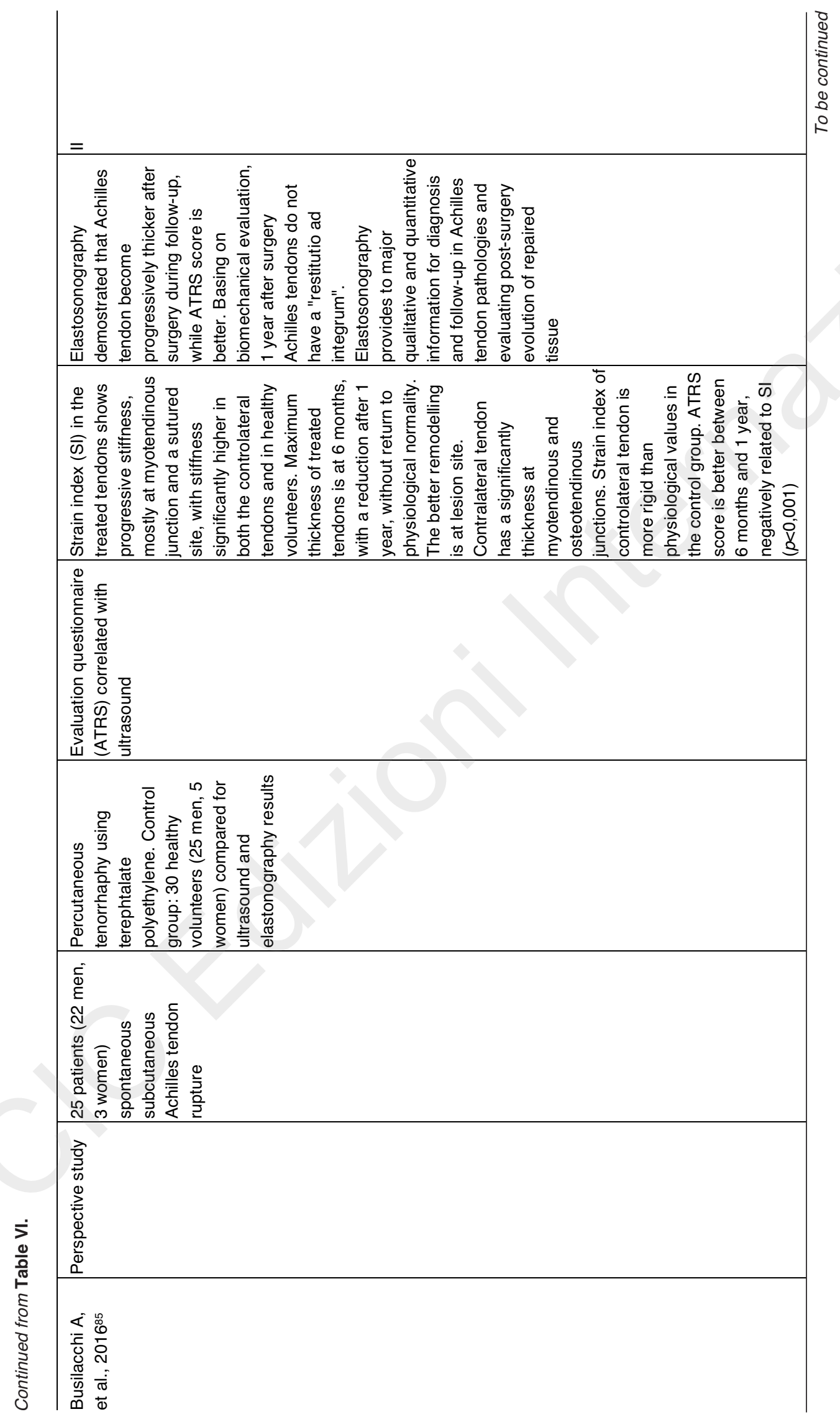




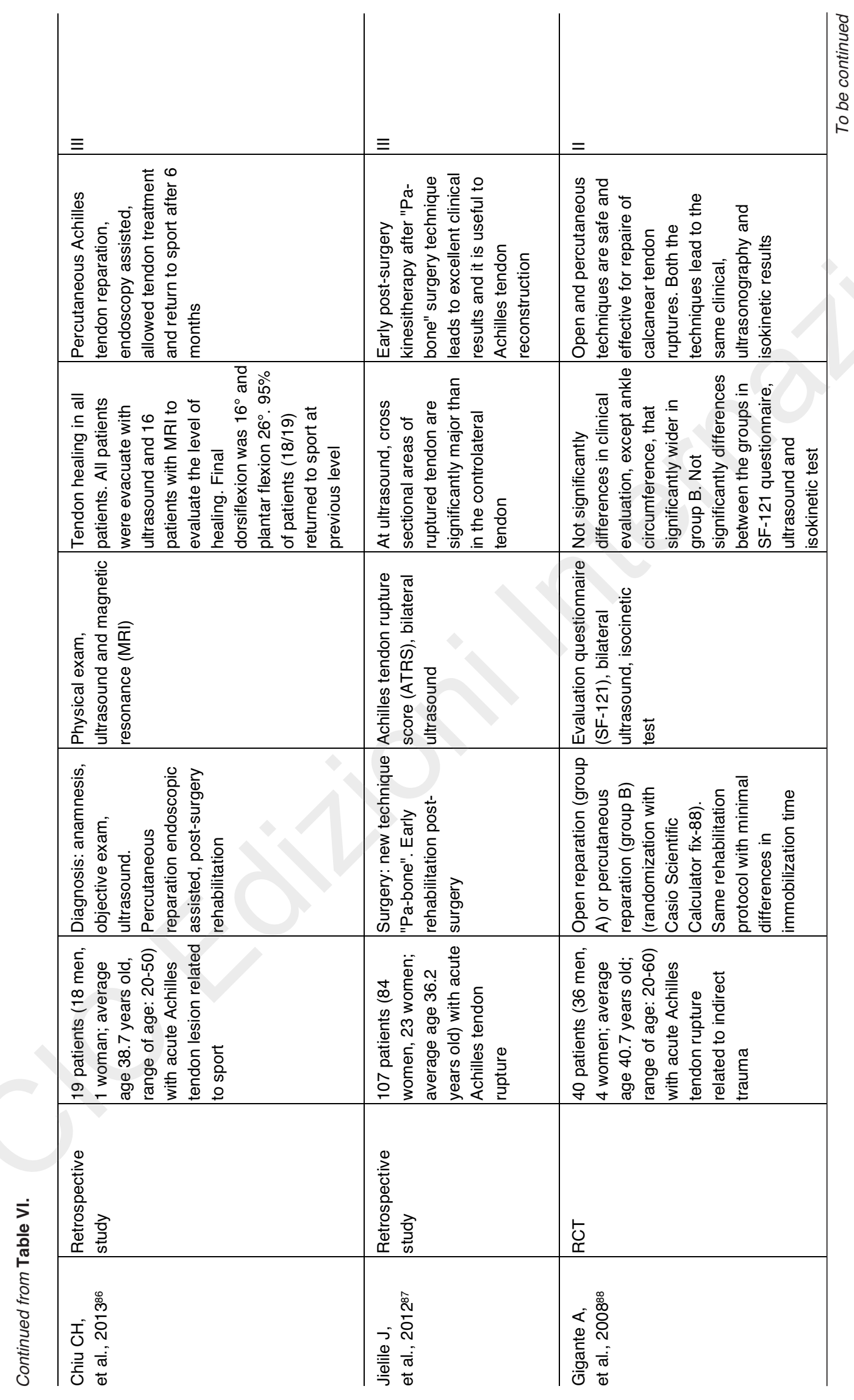




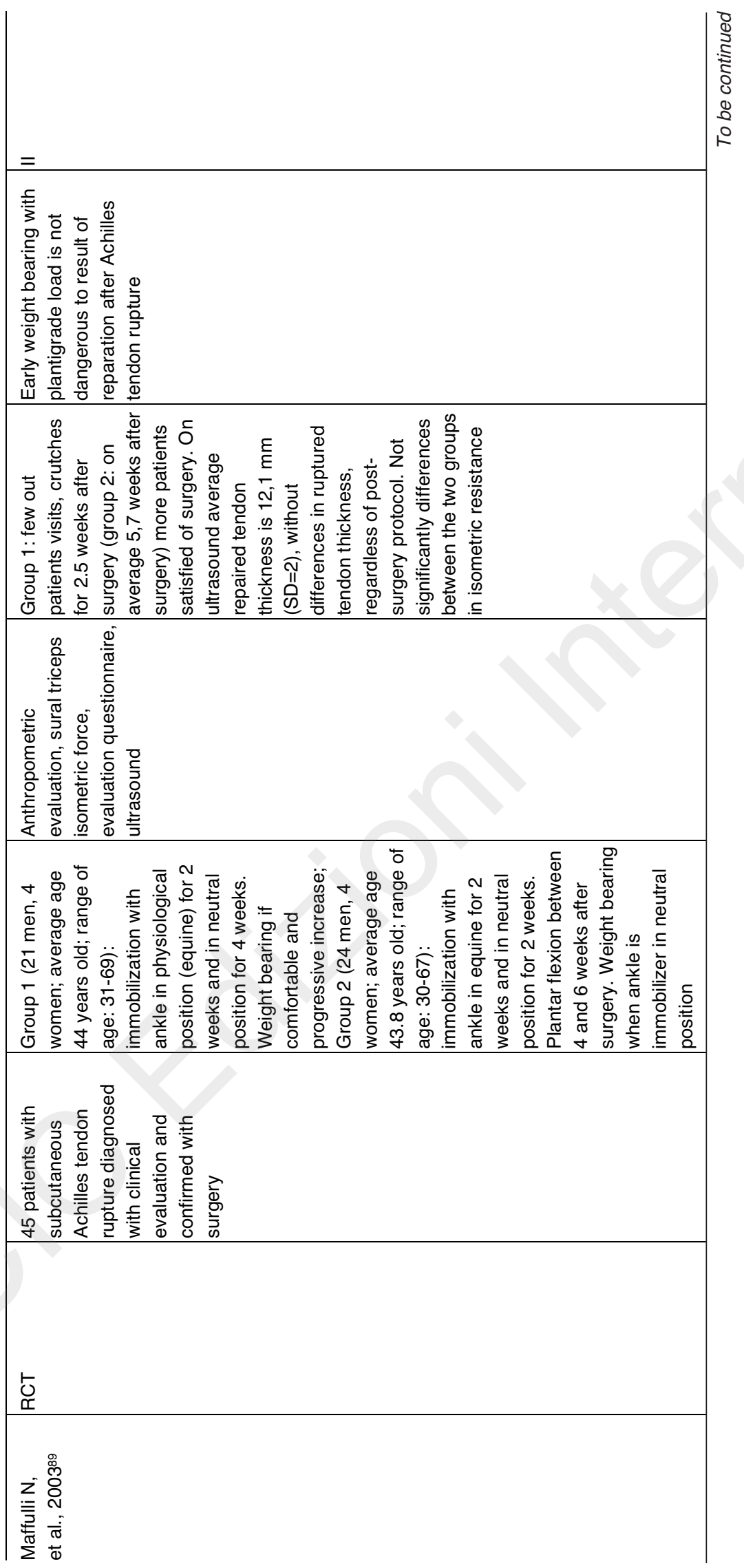




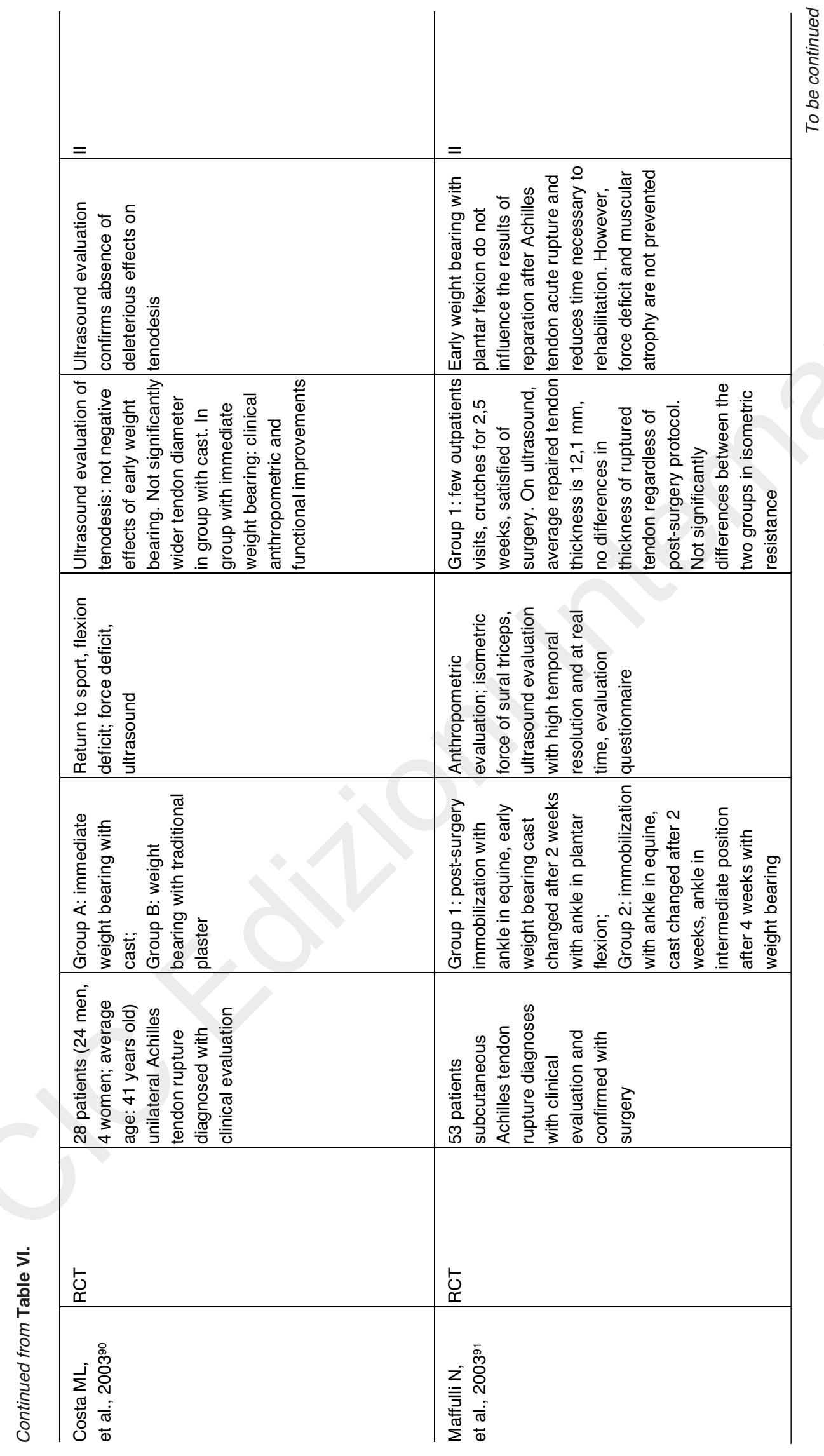




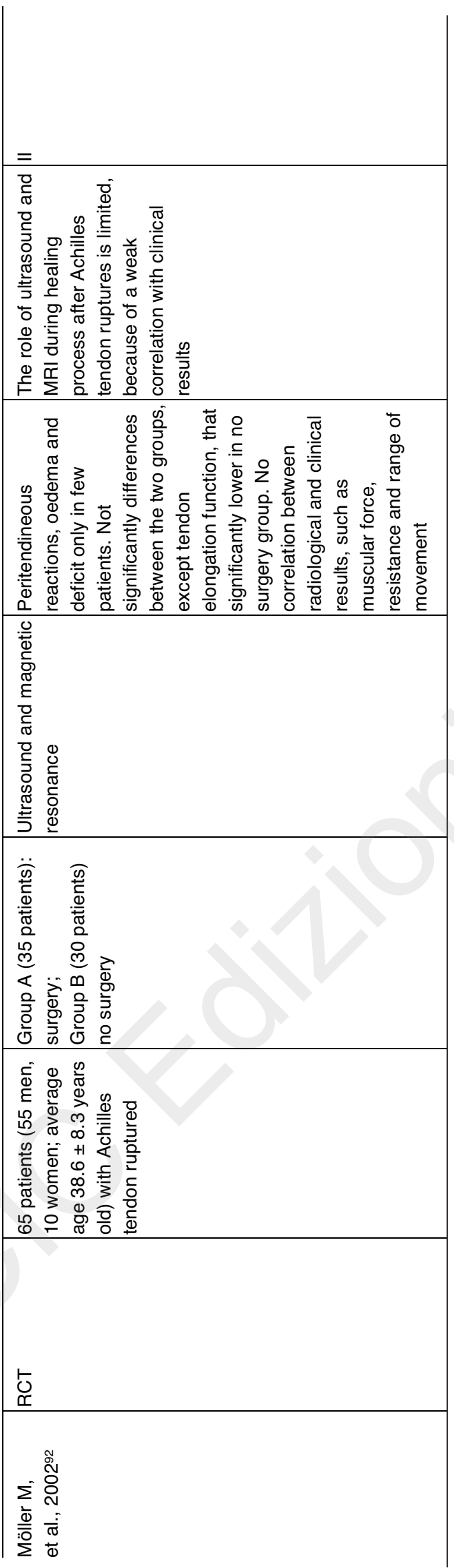

cularity within and around repaired tendons and the total blood flow amount consistently and predictably decrease with time ${ }^{229}$. The increased vascularity showed by Power Doppler indicated a possible healing progress of repaired Achilles tendon and it persisted until avascular scar formation.

In the last years ultrasound elastosonography increased its diagnostic utility with the introduction of shear wave method (SWE), a non-invasive ultrasonographic imaging technique introduced in 2002 which has the advantage of being operator-independent, reproducible, and quantitative ${ }^{230}$.

Healthy Achilles tendons have a hard elastographic pattern, whereas pathologic ones show a reduction in stiffness. After surgical treatment of a complete tear, tendon stiffness pattern gradually increases at 12, 24, and 48 weeks as the wound-healing process continues $^{230,231}$.

If an Achilles tendon re-rupture is suspected, sonographic diagnosis is more difficult due to the structural characteristics of the tendon, particularly if large fluid collections are present; a dynamic evaluation during ankle flexion and extension is helpful in revealing the gap of tendon discontinuity ${ }^{224}$.

\section{Magnetic resonance imaging}

MR imaging can be useful to evaluate the healing process of a surgically treated Achilles tendon.

In almost all surgically repaired Achilles tendons, high signal intensity areas (on fluid sensitive sequences) at the rejoined tendon ends was identified. This finding was clearly seen between 6 weeks and 3 months postoperatively; 6 months after, this area had reduced greatly in size. The high-signal intensity findings on MR images seems to be correlate with the healing response and with the actual tendon tissue composition with respect to morphology and biochemistry ${ }^{232}$.

Fujikawa, et al. explored the MRI features of normal healing of the expected residual gap in the Achilles tendon after surgical repair. MRI images showed visible gap on MR imaging on 4 weeks after surgery on T1-WI and T2-WI images, both after percutaneous repair and after open surgery. At 8 weeks a gap was visible on T1-weighted MR images in $80 \%$ after percutaneous repair and in $10 \%$ after open surgical repair; T2-weighted MR images showed a tendon gap in $63 \%$ but in none of the tendons in the open surgical repair group. After 12 weeks, neither T1-weighted nor T2-weighted images showed a tendon gap in both the two tendon's group ${ }^{233}$.

Karjalainen, et al. analysed 21 surgically repaired Achilles tendon ruptures with imaging at 3 and 6 weeks, and at 3 and 6 months after surgery and found intratendinous area of high-intensity signal in almost all surgically repaired Achilles tendons (19/21) at 3 months after surgery on PD (proton density) and T2-WI $\mathrm{W}^{234}$.

Hahn, et al. demonstrated the postoperative MR course after flexor hallucis longus tendon transfer and described that full tendon integration can be expected only in half the patients and fatty muscle degeneration in 
Table VII. Answer n. 5: Conservative treatment.

\begin{tabular}{|c|c|c|c|c|c|c|}
\hline Author & $\begin{array}{l}\text { Type of } \\
\text { study }\end{array}$ & Protocol & $\begin{array}{l}\text { Follow-up } \\
\text { (months) }\end{array}$ & $\begin{array}{l}\text { Outcome } \\
\text { assessment }\end{array}$ & Results & $\begin{array}{l}\text { Level of } \\
\text { evidence }\end{array}$ \\
\hline $\begin{array}{l}\text { Neumayer F, } \\
\text { et al. }{ }^{98} 2010\end{array}$ & $\begin{array}{l}\text { Prospective } \\
\text { not } \\
\text { randomized }\end{array}$ & $\begin{array}{l}\text { Dynamic cast and } \\
\text { early mobilization }\end{array}$ & 60 & $\begin{array}{l}\text { Leppilahti ankle } \\
\text { score, isokinetic } \\
\text { strenght }\end{array}$ & Good functional results & III \\
\hline $\begin{array}{l}\text { Metz R, et al. }{ }^{99} \\
2008\end{array}$ & RCT & $\begin{array}{l}\text { Surgery vs } \\
\text { conservative } \\
\text { treatment }\end{array}$ & 6 & $\begin{array}{l}\text { Isokinetic strenght, } \\
\text { ROM }\end{array}$ & $\begin{array}{l}\text { Not significant } \\
\text { differences between } \\
\text { the two groups }\end{array}$ & II \\
\hline $\begin{array}{l}\text { Willits K, et al. }{ }^{100} \\
2010\end{array}$ & $\mathrm{RCT}$ & $\begin{array}{l}\text { Surgery vs } \\
\text { conservative } \\
\text { treatment }\end{array}$ & 24 & $\begin{array}{l}\text { Re-ruptures, } \\
\text { isokinetic strenght, } \\
\text { ROM, Leppilahti } \\
\text { score, calf } \\
\text { circumference }\end{array}$ & $\begin{array}{l}\text { Less complications } \\
\text { with conservative } \\
\text { treatment, similar } \\
\text { functional results }\end{array}$ & 1 \\
\hline $\begin{array}{l}\text { Nillson-Helander } \\
\text { K, et al. }{ }^{7} 2010\end{array}$ & $\mathrm{RCT}$ & $\begin{array}{l}\text { Surgery vs } \\
\text { conservative } \\
\text { treatment }\end{array}$ & 12 & $\begin{array}{l}\text { ATRS, functional } \\
\text { tests }\end{array}$ & $\begin{array}{l}\text { Not significant } \\
\text { differences between } \\
\text { the two groups }\end{array}$ & I \\
\hline $\begin{array}{l}\text { Soroceanu A, et } \\
\text { al. }{ }^{101} 2012\end{array}$ & $\begin{array}{l}\text { Meta-analysis } \\
\text { of RCT }\end{array}$ & $\begin{array}{l}\text { Surgery vs } \\
\text { conservative } \\
\text { treatment }\end{array}$ & - & $\begin{array}{l}\text { Complications, } \\
\text { strenght, calf } \\
\text { circumference, } \\
\text { functional tests }\end{array}$ & $\begin{array}{l}\text { Less complications and } \\
\text { similar functional } \\
\text { results with early } \\
\text { functional rehabilitation }\end{array}$ & 1 \\
\hline $\begin{array}{l}\text { Wilkins R, et } \\
\text { al. }{ }^{102} 2012\end{array}$ & $\begin{array}{l}\text { Meta-analysis } \\
\text { of RCT }\end{array}$ & $\begin{array}{l}\text { Open surgery vs } \\
\text { conservative } \\
\text { treatment }\end{array}$ & - & $\begin{array}{l}\text { Re-ruptures and } \\
\text { other complications }\end{array}$ & $\begin{array}{l}\text { Less re-ruptures but } \\
\text { major complications } \\
\text { with surgery }\end{array}$ & I \\
\hline $\begin{array}{l}\text { Olsson } N \text {, et } \\
\text { al. }{ }^{103} 2013\end{array}$ & $\mathrm{RCT}$ & $\begin{array}{l}\text { Surgery + early } \\
\text { rehabilitation } v s \\
\text { conservative } \\
\text { treatment }\end{array}$ & 12 & $\begin{array}{l}\text { ATRS, functional } \\
\text { tests, quality of life }\end{array}$ & $\begin{array}{l}\text { Not significant } \\
\text { differences between } \\
\text { the two groups }\end{array}$ & I \\
\hline $\begin{array}{l}\text { Kaniki N, et al. }{ }^{104} \\
2014\end{array}$ & $\begin{array}{l}\text { Comparative } \\
\text { retrospective }\end{array}$ & $\begin{array}{l}\text { Functional } \\
\text { rehabilitation }+ \\
\text { PRP vs functional } \\
\text { rehabilitation }\end{array}$ & 24 & $\begin{array}{l}\text { Isokinetic strenght, } \\
\text { ROM, calf } \\
\text { circumference, } \\
\text { Leppilahti score }\end{array}$ & $\begin{array}{l}\text { Not significant } \\
\text { differences between } \\
\text { the two groups }\end{array}$ & III \\
\hline $\begin{array}{l}\text { Mark- } \\
\text { Christensen T, } \\
\text { et al. }{ }^{105} 2014\end{array}$ & $\begin{array}{l}\text { Meta-analysis } \\
\text { of RCT }\end{array}$ & $\begin{array}{l}\text { Functional } \\
\text { rehabilitation vs } \\
\text { immobilization }\end{array}$ & - & $\begin{array}{l}\text { Complications, } \\
\text { strenght, ROM, } \\
\text { return to work and to } \\
\text { sport }\end{array}$ & $\begin{array}{l}\text { Better results with the } \\
\text { functional rehabilitation }\end{array}$ & II \\
\hline $\begin{array}{l}\text { Young SW, } \\
\text { et al. } 1062014\end{array}$ & $\mathrm{RCT}$ & $\begin{array}{l}\text { Early weight } \\
\text { bearing vs not } \\
\text { weight bearing } \\
\text { for } 8 \text { weeks }\end{array}$ & 24 & $\begin{array}{l}\text { Re-ruptures, return } \\
\text { to work and to sport, } \\
\text { pain, stiffness }\end{array}$ & $\begin{array}{l}\text { Not significant } \\
\text { differences between } \\
\text { the two groups }\end{array}$ & I \\
\hline $\begin{array}{l}\text { Zhang } \mathrm{H} \text {, } \\
\text { et al. }{ }^{107} 2015\end{array}$ & $\begin{array}{l}\text { Review of } \\
\text { meta-analysis }\end{array}$ & $\begin{array}{l}\text { Surgery vs } \\
\text { conservative } \\
\text { treatment }\end{array}$ & - & $\begin{array}{l}\text { Complications, ROM, } \\
\text { calf circumference, } \\
\text { functional tests }\end{array}$ & $\begin{array}{l}\text { Different complications } \\
\text { for major re-ruptures } \\
\text { with surgery, not other } \\
\text { significant differences } \\
\text { between the two } \\
\text { groups }\end{array}$ & II \\
\hline $\begin{array}{l}\text { Lantto I, et al. }{ }^{108} \\
2015\end{array}$ & $\mathrm{RCT}$ & $\begin{array}{l}\text { Surgery vs } \\
\text { conservative } \\
\text { treatment }\end{array}$ & 18 & $\begin{array}{l}\text { Leppilahti score, } \\
\text { isokinetic strenght }\end{array}$ & $\begin{array}{l}\text { Similar functional } \\
\text { results, but force, ROM } \\
\text { and quality of life better } \\
\text { with surgery }\end{array}$ & I \\
\hline
\end{tabular}


Table VIII. Answer n. 5: Conservative treatment.

\begin{tabular}{|c|c|c|c|c|c|}
\hline Author & Type of study & $\begin{array}{l}\mathrm{N}^{\circ} \text { of } \\
\text { studies/patients }\end{array}$ & Topic & Results & $\begin{array}{l}\text { Level of } \\
\text { evidence }\end{array}$ \\
\hline $\begin{array}{l}\text { Khan RJ, } \\
\text { et al. }{ }^{109} \\
2010\end{array}$ & $\begin{array}{l}\text { Meta-analysis } \\
\text { (RCTs) }\end{array}$ & 12 & $\begin{array}{l}\text { Conservative treatment } \\
\text { vs surgery } \\
\text { Different techniques of } \\
\text { tenorrhaphy }\end{array}$ & $\begin{array}{l}\text { Surgery: less risk } \\
\text { of recurrence and } \\
\text { major risk of } \\
\text { complications, in } \\
\text { particular with } \\
\text { open technique }\end{array}$ & 1 \\
\hline $\begin{array}{l}\text { Gigante A, } \\
\text { et al. }{ }^{88} 2008\end{array}$ & RCT & 40 & $\begin{array}{l}\text { Open vs percutaneous } \\
\text { technique }\end{array}$ & $\begin{array}{l}\text { Less complications } \\
\text { and recovery time } \\
\text { with percutaneous } \\
\text { technique }\end{array}$ & II \\
\hline $\begin{array}{l}\text { Aviña } \\
\text { Valencia JA, } \\
\text { et al. }{ }^{110} 2009\end{array}$ & RCT & 56 & $\begin{array}{l}\text { Open vs mini-invasive } \\
\text { technique }\end{array}$ & $\begin{array}{l}\text { Less complications } \\
\text { and recovery time } \\
\text { with mini-invasive } \\
\text { technique }\end{array}$ & II \\
\hline $\begin{array}{l}\text { Kou J, } 111 \\
2010\end{array}$ & Guidelines & 8 & Open surgery - all outcomes & $\begin{array}{l}\text { Attention at } \\
\text { diabetic patients, } \\
\text { smokers, }>65 \\
\text { years old, } \\
\text { sedentary, obese } \\
\text { (BMI >30), } \\
\text { neuropathic and } \\
\text { with local or } \\
\text { systemic } \\
\text { dermatologic } \\
\text { pathologies }\end{array}$ & IV \\
\hline $\begin{array}{l}\text { Wilkins R, } \\
\text { et al. }{ }^{102} 2012\end{array}$ & $\begin{array}{l}\text { Review of } \\
\text { randomized } \\
\text { studies }\end{array}$ & 7 & $\begin{array}{l}\text { Conservative treatment } \\
\text { vs surgery }\end{array}$ & $\begin{array}{l}\text { Less incidence of } \\
\text { recurrence with } \\
\text { surgery }\end{array}$ & I \\
\hline $\begin{array}{l}\text { Jiang N, } \\
\text { et al.112 } 2012\end{array}$ & $\begin{array}{l}\text { Review of } \\
\text { randomized } \\
\text { studies }\end{array}$ & 10 & $\begin{array}{l}\text { Conservative treatment } \\
\text { vs surgery }\end{array}$ & $\begin{array}{l}\text { Surgery: major } \\
\text { complications risk } \\
\text { but early functional } \\
\text { recovery and less } \\
\text { risk of recurrence }\end{array}$ & 1 \\
\hline $\begin{array}{l}\text { Jones MP, } \\
\text { et al.113 } 2012\end{array}$ & $\begin{array}{l}\text { Review of } \\
\text { randomized } \\
\text { studies or almost } \\
\text { randomized }\end{array}$ & 4 & $\begin{array}{l}\text { Conservative treatment } \\
\text { vs surgery } \\
\text { Open vs percutaneous } \\
\text { technique }\end{array}$ & $\begin{array}{l}\text { Less complications } \\
\text { risk. } \\
\text { Not differences in } \\
\text { recurrence. Major } \\
\text { infection risk with } \\
\text { open technique. } \\
\text { Not differences in } \\
\text { sural nerve lesions, } \\
\text { TVP and } \\
\text { hematomas. }\end{array}$ & I \\
\hline $\begin{array}{l}\text { Wu Y, et al. }{ }^{114} \\
2016\end{array}$ & $\begin{array}{l}\text { Review of meta- } \\
\text { analysis }\end{array}$ & 9 & $\begin{array}{l}\text { Conservative treatment } \\
\text { vs surgery }\end{array}$ & $\begin{array}{l}\text { Less risk of } \\
\text { recurrence and } \\
\text { major risk of } \\
\text { complications with } \\
\text { surgery }\end{array}$ & 1 \\
\hline
\end{tabular}




\section{F. Oliva et al.}

Continued from Table VIII.

\begin{tabular}{|c|c|c|c|c|c|}
\hline $\begin{array}{l}\text { Miyamoto W, } \\
\text { et al. }{ }^{115} 2017\end{array}$ & Retrospective & 44 & Double locked suture & $\begin{array}{l}\text { Correct tendon } \\
\text { tension, good } \\
\text { functional results, } \\
\text { early recovery }\end{array}$ & IV \\
\hline $\begin{array}{l}\text { Yang B, } \\
\text { et al. }{ }^{116} 2017\end{array}$ & $\begin{array}{l}\text { Meta-analysis of } \\
\text { RCT and } \\
\text { retrospective } \\
\text { studies }\end{array}$ & 12 & $\begin{array}{l}\text { Open vs percutaneous } \\
\text { technique }\end{array}$ & $\begin{array}{l}\text { - Open technique: } \\
\text { major risk of deep } \\
\text { infections } \\
\text { - Percutaneous } \\
\text { technique: major } \\
\text { risk of sural nerve } \\
\text { lesions, less } \\
\text { surgery time, better } \\
\text { AOFAS score } \\
\text { - No significantly } \\
\text { differences in } \\
\text { recurrence } \\
\text { incidence, in } \\
\text { thrombotic risk, in } \\
\text { ankle ROM, in } \\
\text { sural triceps } \\
\text { tropism }\end{array}$ & 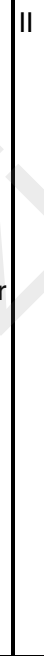 \\
\hline $\begin{array}{l}\text { Del Buono A, } \\
\text { et al. }{ }^{117} 2014\end{array}$ & $\begin{array}{l}\text { Meta-analysis of } \\
\text { RCT and } \\
\text { retrospective } \\
\text { studies }\end{array}$ & 12 & $\begin{array}{l}\text { Open vs mini-invasive } \\
\text { technique }\end{array}$ & $\begin{array}{l}\text { Less complications } \\
\text { and major ROM } \\
\text { with mini-invasive } \\
\text { technique }\end{array}$ & 1 \\
\hline $\begin{array}{l}\text { Li CG, et al. }{ }^{118} \\
2017\end{array}$ & Retrospective & 24 & $\begin{array}{l}\text { Single bundle termino-terminal } \\
\text { suture }\end{array}$ & $\begin{array}{l}\text { After } 1 \text { year: mean } \\
\text { AOFAS score: } \\
92.4 \pm 5.9 . \text { Not } \\
\text { differences in } \\
\text { dorsiflexion, } \\
\text { plantar flexion and } \\
\text { muscular tropism } \\
\text { with contralateral } \\
\text { limb }\end{array}$ & IV \\
\hline $\begin{array}{l}\text { Lewis N, } \\
\text { et al. }{ }^{119} 2003\end{array}$ & $\begin{array}{l}\text { Controlled on } \\
\text { cadaver }\end{array}$ & / & $\begin{array}{l}\text { Reparation with Teno Fix } \\
\text { anchor }\end{array}$ & $\begin{array}{l}\text { Good stumps } \\
\text { approach, less risk } \\
\text { of gap formation }\end{array}$ & III \\
\hline $\begin{array}{l}\text { Manent A, } \\
\text { et al. }{ }^{120} 2017\end{array}$ & $\begin{array}{l}\text { Controlled on } \\
\text { cadaver }\end{array}$ & / & $\begin{array}{l}\text { Differents techniques of } \\
\text { tenorrhaphy }\end{array}$ & $\begin{array}{l}\text { Bunnel technique: } \\
\text { less risk of } \\
\text { lengthening }\end{array}$ & III \\
\hline $\begin{array}{l}\text { Aktas S, } \\
\text { et al. }{ }^{121} 2007\end{array}$ & Perspective & 30 & $\begin{array}{l}\text { Termino-terminal suture vs } \\
\text { augmentation }\end{array}$ & $\begin{array}{l}\text { Less complications } \\
\text { with termino- } \\
\text { terminal suture }\end{array}$ & III \\
\hline $\begin{array}{l}\text { Oze Mr, } \\
\text { et al. }{ }^{122} 2016\end{array}$ & Retrospective & 23 & $\begin{array}{l}\text { Gastrocnemius rotation flap, } \\
\text { associated with crural fascia } \\
\text { incision }\end{array}$ & $\begin{array}{l}\text { Mean AOFAS } \\
\text { score: } 98.2 \pm 2.3 \\
\text { (range } 93-100 \text { ) }\end{array}$ & IV \\
\hline
\end{tabular}


Table IX. Answer n. 6: Sutures and materials.

\begin{tabular}{|c|c|c|c|c|c|c|}
\hline Author & Type of study & Protocol & $\begin{array}{l}\text { Follow-up } \\
\text { (months) }\end{array}$ & $\begin{array}{l}\text { Outcome } \\
\text { assessment }\end{array}$ & Results & $\begin{array}{l}\text { Level of } \\
\text { evidence }\end{array}$ \\
\hline $\begin{array}{l}\text { Kocaoglu B, } \\
\text { et al. }{ }^{123} 2015\end{array}$ & $\begin{array}{l}\text { Perspective not } \\
\text { randomized }\end{array}$ & $\begin{array}{l}\text { Absorbable vs not } \\
\text { absorbable suture }\end{array}$ & - & $\begin{array}{l}\text { AOFAS hindfoot } \\
\text { clinical outcome } \\
\text { scores, return to } \\
\text { work, } \\
\text { complications }\end{array}$ & $\begin{array}{l}\text { Less risk of } \\
\text { complications with } \\
\text { absorbable suture }\end{array}$ & II \\
\hline $\begin{array}{l}\text { Kara A, et al. } \\
{ }_{124} 2014\end{array}$ & Case report & - & 12 & $\begin{array}{l}\text { Post-surgery } \\
\text { complications }\end{array}$ & $\begin{array}{l}\text { Granuloma formation } \\
\text { with non absorbable } \\
\text { suture }\end{array}$ & V \\
\hline $\begin{array}{l}\text { Ollivere BJ, et } \\
\text { al. }{ }^{125} 2014\end{array}$ & Case report & - & 8 & $\begin{array}{l}\text { Post -surgery } \\
\text { complications }\end{array}$ & $\begin{array}{l}\text { Granuloma formation } \\
\text { with FiberWire suture } \\
\text { (silicone and } \\
\text { polyethylene) }\end{array}$ & $\mathrm{V}$ \\
\hline $\begin{array}{l}\text { Baig MN, } \\
\text { et al. }{ }^{126} 2017\end{array}$ & $\begin{array}{l}\text { Perspective not } \\
\text { randomized }\end{array}$ & $\begin{array}{l}\text { Absorbable vs not } \\
\text { absorbable suture }\end{array}$ & 6 & $\begin{array}{l}\text { Complications } \\
\text { (infections), } \\
\text { Boyden score }\end{array}$ & $\begin{array}{l}\text { Major risk of } \\
\text { complications and } \\
\text { worse Boyden score } \\
\text { with absorbable } \\
\text { suture }\end{array}$ & II \\
\hline $\begin{array}{l}\text { Sadoghi P, } \\
\text { et al. }{ }^{127} 2012\end{array}$ & $\begin{array}{l}\text { Systematic } \\
\text { review }\end{array}$ & $\begin{array}{l}\text { Different suture } \\
\text { techniques evaluation } \\
\text { (Kessler, Bunnell, } \\
\text { Krackow, Achillon, } \\
\text { Ma-Griffith, giftbox) }\end{array}$ & - & $\begin{array}{l}\text { Resistance to } \\
\text { rupture }\end{array}$ & $\begin{array}{l}\text { Impossible to define } \\
\text { better technique }\end{array}$ & II \\
\hline $\begin{array}{l}\text { Manent A, } \\
\text { et al. }{ }^{120} 2017\end{array}$ & $\begin{array}{l}\text { Perspective not } \\
\text { randomized }\end{array}$ & $\begin{array}{l}\text { Different suture } \\
\text { techniques evaluation } \\
\text { (double Kessler, } \\
\text { double Bunnell, } \\
\text { Krackow, Ma-Griffith) }\end{array}$ & - & $\begin{array}{l}\text { Resistance to } \\
\text { rupture }\end{array}$ & $\begin{array}{l}\text { - Double Bunnel: } \\
\text { major resistance, } \\
\text { less risk of tendon } \\
\text { lengthening } \\
\text { - Krackow technique: } \\
\text { same resistance, } \\
\text { major lengthening }\end{array}$ & III \\
\hline $\begin{array}{l}\text { Herbort M, } \\
\text { et al. }{ }^{128} 2008\end{array}$ & $\begin{array}{l}\text { Perspective not } \\
\text { randomized }\end{array}$ & $\begin{array}{l}\text { Bunnell vs Kessler on } \\
\text { cavader }\end{array}$ & - & $\begin{array}{l}\text { Resistance to } \\
\text { cyclic loads }\end{array}$ & $\begin{array}{l}\text { Similar } \\
\text { biomechanical } \\
\text { properties }\end{array}$ & II \\
\hline $\begin{array}{l}\text { McCoy BW, } \\
\text { et al. }{ }^{129} 2010\end{array}$ & $\begin{array}{l}\text { Perspective not } \\
\text { randomized }\end{array}$ & $\begin{array}{l}\text { Different suture } \\
\text { techniques evaluation } \\
\text { (double Kessler, } \\
\text { double Bunnell, } \\
\text { double Krackow) }\end{array}$ & - & $\begin{array}{l}\text { Resistance to } \\
\text { rupture }\end{array}$ & $\begin{array}{l}\text { No differences in } \\
\text { resistance }\end{array}$ & III \\
\hline
\end{tabular}

the gastrocnemius muscle and soleus muscle is commonly seen after this technique. ${ }^{235}$

The analysis of gadolinium contrast agent enhancement (Gd-CME) images shows larger high signal intensity alterations than on T1-WI before CME or on T2-WI; this finding slowly decreased with time and, at the 2year MR follow-up, there was no significant intratendinous signal enhancement. This supports the hypothesis that the Gd-contrast agent interacts with the pathological intratendinous tendon healing process ${ }^{232}$.

One year after surgery, adhesions between the tendon and the skin may be reported in as many as $40 \%$ of the patients ${ }^{236}$. The surgical wound scar may be clearly detected on MR images; there was no high signal intensity subcutaneous fat tissue on images and the tendon seemed to be attached to the skin at the site of the scar, thereby preventing the correct range of motion of the tendon ${ }^{237}$.

\section{Advanced MRI application}

The use of diffusion tensor imaging (DTI) in musculoskeletal field keeps on growing not only in experimental settings but also in clinical practice, reflecting the information about the architectural organization of tissue. After surgical procedures the use of DTI may ascertain the microstructural properties and integrity restoration of the ruptured tendon during the healing process $^{238}$. 
Table X. Answer n. 7: Use of autologous derived blood products.

\begin{tabular}{|c|c|c|c|c|c|c|}
\hline Author & Year & Type of study & $\begin{array}{l}\text { Level of } \\
\text { evidence }\end{array}$ & N. of patients & $\begin{array}{l}\text { Follow-up } \\
\text { (months) }\end{array}$ & Technical notes \\
\hline Sánchez M, et al. ${ }^{130}$ & 2007 & $\begin{array}{l}\text { Retrospective } \\
\text { (S vs S+PRP) }\end{array}$ & III & $12(6$ vs 6$)$ & - & $\begin{array}{l}\text { Intraoperative } \\
\text { injection }\end{array}$ \\
\hline Shepull T, et al. ${ }^{131}$ & 2011 & RCT (S vs S+PRP) & II & $\begin{array}{l}30 \text { (14 S vs } 16 \\
\text { S+PRP) }\end{array}$ & 12 & $\begin{array}{l}\text { Intraoperative } \\
\text { injection }\end{array}$ \\
\hline Kaniki N, et al. ${ }^{104}$ & 2014 & $\begin{array}{l}\text { Retrospective } \\
\text { (S vs PRP) }\end{array}$ & III & $\begin{array}{l}145 \text { (72 vs } 73 \\
\text { PRP) }\end{array}$ & 24 & No surgery \\
\hline De Carli A, et al. ${ }^{132}$ & 2016 & $\begin{array}{l}\text { Comparative } \\
\text { (S vs S+PRP) }\end{array}$ & IV & $\begin{array}{l}30 \text { (15 S vs } 15 \\
\text { S+PRP) }\end{array}$ & 6 & $\begin{array}{l}\text { Intraoperative } \\
\text { injection and } \\
\text { after } 14 \text { days }\end{array}$ \\
\hline Alvitti $F$, et al. ${ }^{133}$ & 2017 & $\begin{array}{l}\text { Retrospective } \\
\text { (S vs S+PRF } \\
\text { vs control group) }\end{array}$ & IV & $\begin{array}{l}28 \text { (9 S vs } 11 \\
\text { S+PRF vs } 8 \\
\text { control group) }\end{array}$ & 6 & PRF application \\
\hline Zou J, et al. ${ }^{134}$ & 2017 & $\mathrm{RCT}(\mathrm{S} v s \mathrm{~S}+\mathrm{PRP})$ & II & $\begin{array}{l}36 \text { (20 S vs } 16 \\
\text { S+PRP) }\end{array}$ & 24 & $\begin{array}{l}\text { Intraoperative } \\
\text { injection }\end{array}$ \\
\hline
\end{tabular}

S, Surgery (tenorrhaphy); PRP, platelet-rich plasma; PRF, platelet-rich fibrin.

Sarman, et al. analysed pre and postoperative DTI imaging of the Achilles tendon of 16 patients with median duration of follow-up of 21 (range 6 to 80 ) months; the tendon fractional anisotropy values of the ruptured Achilles tendon were statistically significantly lower than those of the normal side $(p=.001)^{238}$.

\section{Answer n. 13: Rehabilitation protocol after acute ruptures (Tabs. XV, XVI)}

Answer n. 14: Rehabilitation protocol after chronic ruptures

Regardless of treatment, timing does not change, depending on biological healing $249-264$.

\section{Rate of recurrence}

The American Academy of Orthopaedic Surgeons (AAOS) guidelines ${ }^{265,111}$ published in. 2010, underline the necessity of a cast in the first phases after accident. A meta-analysis of $2012^{266}$ reports a significantly rate of post-surgery re-rupture after plaster (3.5\%) and after utilised of functional cast (5\%). In other studies $267-269$ the rate of recurrence is $3.3 \%$ after an accelerated rehabilitative protocol with functional cast and $11.4 \%$ with post-surgery plaster.

\section{Rehabilitation protocol}

An evidence based optimal protocol does not exist. In
2008, the Swansea Morriston Achilles Rupture Treatment (SMART) Programme was proposed 270 . Usually, it is recommended a cast at $30^{\circ}$ of plantar flexion for 2 weeks with progressive weight bearing until $8^{\circ}-9^{\circ}$ weeks ${ }^{240-271}$. Other Authors recommend the use of a cast at $20^{\circ}$ of equinism for the first weeks after tenorrhaphy until start of rehabilitative programme 272 . Full ankle and limb motion is recommended after 8-9 weeks and return to sport is allowed after 6-9 months $240-271$. There is no standard protocol but only some guidance according to biological healing time considering the better synthesis of collagene and the improvement of tendon viscoelastic properties after the first weeks. Physical therapy is a part of protocol reducing inflammatory processes and pain during physiotherapy ${ }^{273}$.

\section{Instrumental physiotherapy}

Instrumental physiotherapy has therapeutic effects: analgesia, activation of local metabolism, relaxing or muscle tonification. Therefore, instrumental physiotherapy can be utilised in most of therapeutic and rehabilitative programmes in association with other methods ${ }^{273}$.

Answer n. 15: Nutraceuticals (Tabs. XVII, XVIII) 
Table XI. Answer n. 8: Open surgery.

\begin{tabular}{|c|c|c|c|c|c|c|}
\hline Author & Year & Type of study & $\begin{array}{l}\text { Level of } \\
\text { evidence }\end{array}$ & $\begin{array}{l}\text { N. of patients } \\
\text { ( } \mathrm{P} \text { vs } \mathrm{O} \text { vs } \mathrm{C})\end{array}$ & Follow-up & Surgery technique \\
\hline Nilsson-Helander $\mathrm{K}$, et al. ${ }^{7}$ & 2010 & $\mathrm{RCT}$ & 1 & 97 (49 vs 48) & $1 \mathrm{y}$ & O vs C \\
\hline Keating JF, et al. ${ }^{135}$ & 2011 & CT & II & 80 (41 vs 39) & $1 \mathrm{y}$ & O vs C \\
\hline Nistor L ${ }^{136}$ & 1981 & RCT & II & 105 (45 vs 60) & $2.5 \mathrm{y}$ & $\mathrm{O} v s \mathrm{C}$ \\
\hline Cetti R, et al. ${ }^{137}$ & 1993 & RCT & II & 111 (65 vs 55$)$ & $1 \mathrm{y}$ & $\mathrm{O}$ vs $\mathrm{C}$ \\
\hline Möller M, et al. ${ }^{138}$ & 2001 & $\mathrm{RCT}$ & II & $112(59$ vs 53$)$ & $2 y$ & Modified Kessler vs C \\
\hline Twaddle BC, et al. ${ }^{139}$ & 2007 & $\mathrm{RCT}$ & II & 50 (25 vs 25) & $1 \mathrm{y}$ & O vc C \\
\hline Willits K, et al. 100 & 2010 & $\mathrm{RCT}$ & II & 144 (72 vs 72) & $2 y$ & O vs C \\
\hline Kołodziej L, et al. ${ }^{140}$ & 2013 & $\mathrm{RCT}$ & II & 47 (22 vs 25) & $3-24 m$ & Achillon vs Krackow \\
\hline Gigante A, et al. 88 & 2008 & $\mathrm{RCT}$ & II & 40 (20 vs 20) & $1 \mathrm{y}$ & Tenolig vs Kessler \\
\hline Cretnik A, et al. ${ }^{141}$ & 2005 & CT & II & 237 (132 vs 105) & $2 y$ & $\mathrm{P}$ vs $\mathrm{O}$ \\
\hline Aktas S, et al. ${ }^{142}$ & 2009 & $\mathrm{RCT}$ & II & 40 (20 vs 20) & $10-48 m$ & Achillon vs Krakow \\
\hline Karabinas $\mathrm{PK}^{143}$ & 2014 & $\mathrm{RCT}$ & II & 34 (19 vs 15) & $9-24 m$ & $\begin{array}{l}\text { Ma and Griffit vs } \\
\text { Krackow }\end{array}$ \\
\hline Lim J, et al. ${ }^{144}$ & 2001 & $\mathrm{RCT}$ & II & 66 (33 vs 33) & NA & Ma-Griffit vs Krackow \\
\hline Aviña Valencia JA, et al. ${ }^{110}$ & 2009 & $\mathrm{RCT}$ & II & 56 (28 vs 28) & $4 \mathrm{~m}$ & Achillon vs Linn \\
\hline Henriquez H, et al. ${ }^{145}$ & 2012 & Retrospective & III & 32 (17 vs 15) & $6-48 m$ & Dresden vs Kessler \\
\hline Carmont MR, et al. ${ }^{146}$ & 2013 & Retrospective & III & 84 (49 vs 35) & $18-70 \mathrm{~m}$ & P vs Kessler \\
\hline Miller D, et al. ${ }^{147}$ & 2005 & Retrospective & III & 140 (54 vs 86$)$ & $3-12 m$ & Ma-Griffit vs Kessler \\
\hline Chan AP, et al. ${ }^{148}$ & 2011 & Retrospective & III & 19 (10 vs 9$)$ & $2-12 m$ & Achillon vs Krackow \\
\hline Goren D, et al. ${ }^{149}$ & 2005 & Retrospective & III & 20 (10 vs 10$)$ & 6-39 m & $\begin{array}{l}\text { P (Ma-Griffit) vs } \\
\mathrm{O} \text { (Krackow) }\end{array}$ \\
\hline Daghino W, et al. ${ }^{150}$ & 2016 & Retrospective & III & 140 & $6 \mathrm{~m}$ & $\mathrm{M}$ (Achillon) vs $\mathrm{O}$ \\
\hline Haji A, et al. ${ }^{151}$ & 2004 & Retrospective & III & 108 (38 vs 70) & NA & $\begin{array}{l}\text { Ma and Griffith vs } \\
\text { Bunnell }\end{array}$ \\
\hline Lewis $\mathrm{N}$, et al. ${ }^{119}$ & 2003 & $\begin{array}{l}\text { Comparative } \\
\text { on cadaver }\end{array}$ & III & 10 & NA & $\begin{array}{l}\text { Teno Fix vs two-strand } \\
\text { modified Kessler repair }\end{array}$ \\
\hline Zhao HM, et al. ${ }^{152}$ & 2011 & Case series & IV & 6 & $2 y$ & $\begin{array}{l}\text { Bundle to bundle } \\
\text { suture }\end{array}$ \\
\hline Li CG, et al. ${ }^{118}$ & 2017 & Case series & IV & 24 & $1 \mathrm{y}$ & $\begin{array}{l}\text { Tendon-bundle } \\
\text { technique }\end{array}$ \\
\hline Ozer $\mathrm{H}$, et al. 122 & 2016 & Case series & IV & 23 & $1 \mathrm{y}$ & $\begin{array}{l}\text { Tenorrhaphy + } \\
\text { gastrocnemius flap }\end{array}$ \\
\hline Miyamoto W, et al.115 & 2017 & Case series & IV & 44 & $2 y$ & $\begin{array}{l}\text { Double side-locking } \\
\text { loop suture }\end{array}$ \\
\hline
\end{tabular}

P, percutanous tenorrhaphy; M, mini-invasive tenorrhaphy; O, open surgery; C, conservative treatment; NA, no application. 


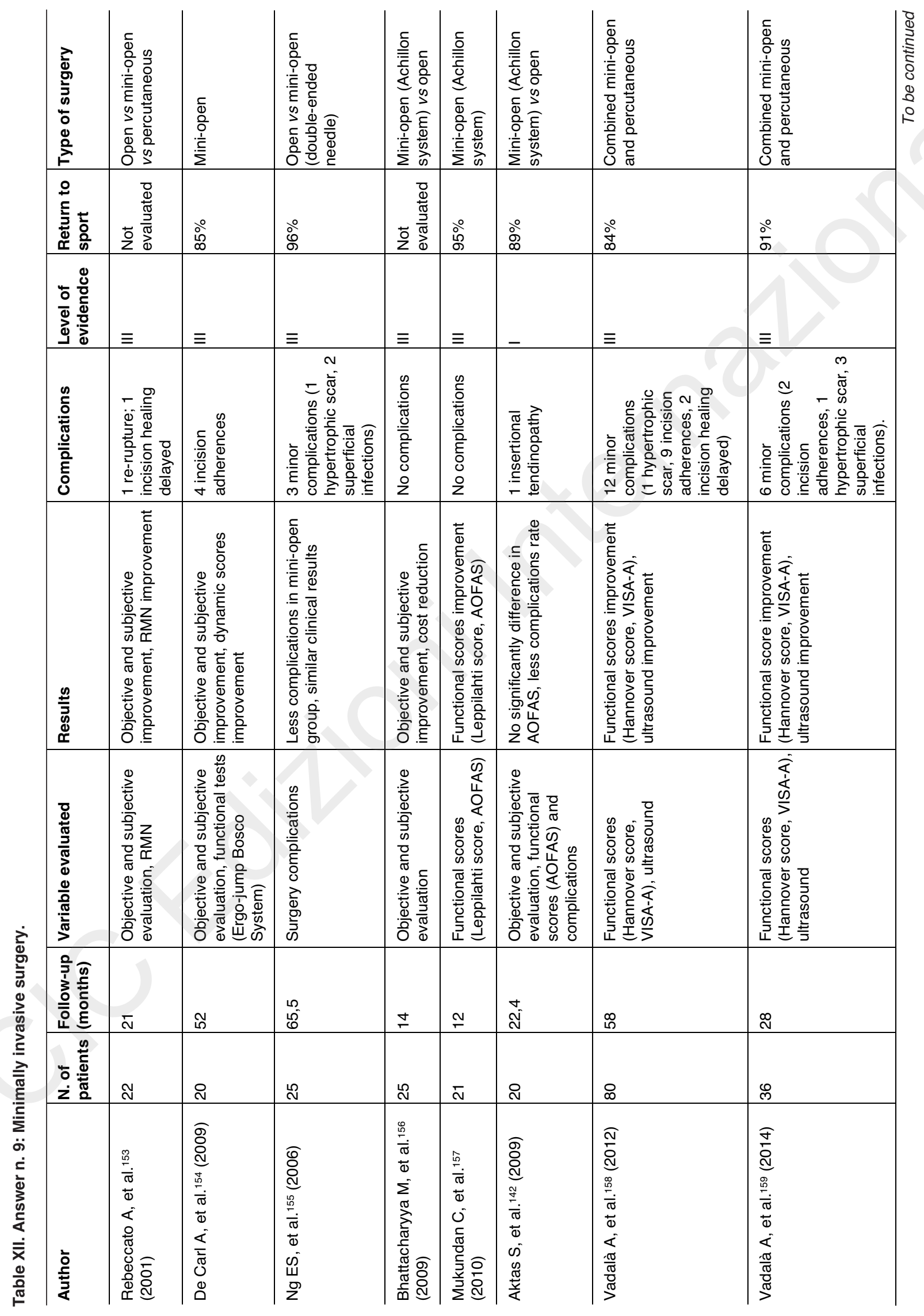




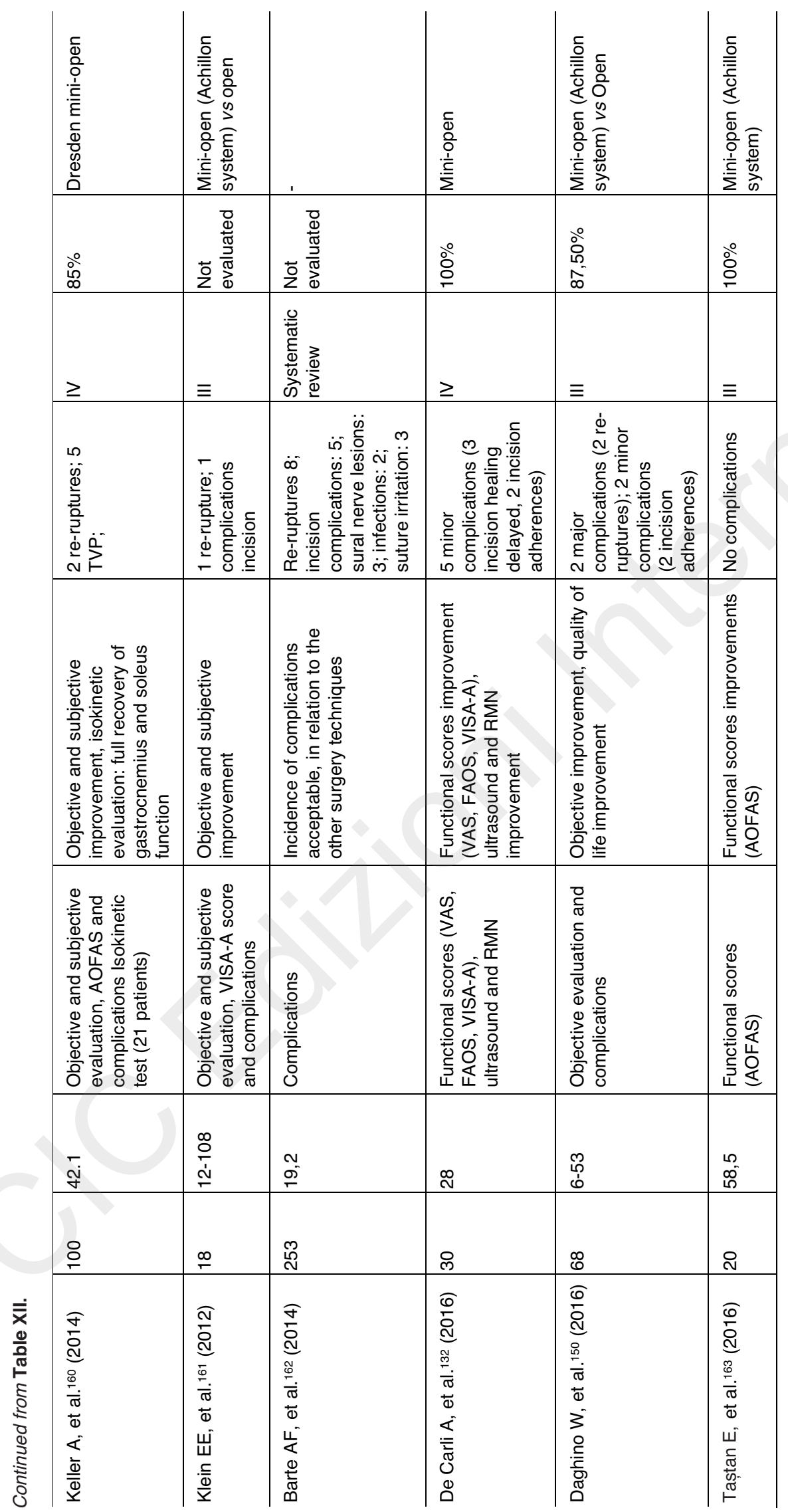


Table XIII. Answer n. 10: Percutaneus surgery.

\begin{tabular}{|c|c|c|c|c|c|c|}
\hline Author & Year & Type of study & $\begin{array}{l}\text { Level of } \\
\text { evidence }\end{array}$ & $\begin{array}{l}\text { N. of patients } \\
\text { (P vs O) }\end{array}$ & $\begin{array}{l}\text { Follow-up } \\
\text { (months) }\end{array}$ & Type of surgery \\
\hline Karabinas PK, et al. ${ }^{143}$ & 2014 & $\mathrm{RCT}(\mathrm{P}$ vs O) & 1 & 34 (19 vs 15) & 22 & Ma and Griffith \\
\hline Gigante A, et al. 88 & 2008 & $\mathrm{RCT}(\mathrm{P}$ vs O) & 1 & 40 (20 vs 20) & 24 & Tenolig ${ }^{\circledR}$ \\
\hline Lim J, et al. ${ }^{144}$ & 2001 & $\mathrm{RCT}(\mathrm{P}$ vs O) & 1 & 66 (33 vs 33) & 6 & Ma and Griffith \\
\hline Jallageas R, et al. ${ }^{164}$ & 2013 & Comparative ( $\mathrm{P}$ vs $\mathrm{O})$ & II & 31 (16 vs 15) & 15 & Tenolig ${ }^{\circledR}$ \\
\hline Cretnik A, et al. ${ }^{141}$ & 2005 & Comparative ( $\mathrm{P}$ vs $\mathrm{O})$ & II & 237 (132 vs 105) & 24 & Ma and Griffith \\
\hline Zayni R, et al. 165 & 2017 & Retrospective (P vs O) & III & 29 (16 vs 13) & 46 & Tenolig ${ }^{\circledR}$ \\
\hline Henriquez $\mathrm{H}$, et al. ${ }^{145}$ & 2012 & Retrospective (P vs O) & III & 32 (17 vs 15) & 18 & Tenolig ${ }^{\circledR}$ \\
\hline Taglialavoro G, et al. ${ }^{166}$ & 2011 & Retrospective (P vs $\mathrm{P}$ ) & III & 60 (30 vs 30) & 24 & $\begin{array}{l}\text { Ma and Griffith vs } \\
\text { Tenolig }{ }^{\circledR}\end{array}$ \\
\hline Haji A, et al. ${ }^{151}$ & 2004 & Retrospective (P vs O) & III & 108 (38 vs 70) & $\begin{array}{l}\text { Not } \\
\text { reported }\end{array}$ & Ma and Griffith \\
\hline Bradley JP, et al. ${ }^{167}$ & 1990 & Comparative ( $\mathrm{P}$ vs $\mathrm{O})$ & III & 27 (12 vs 15) & $\begin{array}{l}\text { Not } \\
\text { reported }\end{array}$ & Ma and Griffith \\
\hline Tenenbaum S, et al. ${ }^{168}$ & 2010 & Case series & IV & 29 & 32 & Ma and Griffith \\
\hline Maes R, et al. 169 & 2006 & Case series & IV & 124 & 23 & Tenolig® \\
\hline Lacoste S, et al. ${ }^{170}$ & 2014 & Case series & IV & 75 & 21 & Tenolig ${ }^{\circledR}$ \\
\hline
\end{tabular}

$\mathrm{P}$, percutaneous tenorrhaphy; $\mathrm{O}$, open surgery.

Answer n. 17: Outcome evaluation devices (Indirect determination of Achilles tendon force during locomotion by motion analysis techniques)

The position of selected anatomical landmarks of the lower limb and the foot-to-ground reaction force, as collected during terrestrial locomotion, represent the experimental data that are sufficient to solve the inverse dynamic problem and estimate the so-called "intersegmental couple" (IC) at the ankle ${ }^{359}$. IC can be considered as a muscle-equivalent representation of the angular actuator responsible for the motion of the foot about the ankle joint center in the sagittal plane during the ground-contact phase. IC results from the contributions of the moments due to: the ground reaction force acting on the foot; the segment's weight; the acceleration force of the segment's center of mass; the segment's angular acceleration ${ }^{360}$. All these quantities can be easily gathered in a motion analysis laboratory. When the sign of IC is negative ${ }^{361}$. The tensile force of the Achilles tendon (AT) can be computed as the ratio between IC and the AT lever arm with respect to the ankle joint center ${ }^{362}$. In fact, as the main plantar-flexor muscles of the ankle converge in the AT and no optimization may be needed as no plantar-flexor muscles redundancy occurs ${ }^{363}$. The AT lever arm is typically estimated from scaled generic musculoskeletal models $^{364}$. A high level of association and a low bias were found between the AT force estimated through inverse dynamics and that measured in vivo with an implanted force transducer ${ }^{365}$.

Several are, however, the limitations of such approach. First, the assumption that IC can be uniquely addressed to the plantar-flexors muscles (hence, excluding co-contraction of antagonist muscles ${ }^{362}$ and neglecting the contribution of passive forces exerted by ligaments $\left.{ }^{366}\right)$. Second, the accuracy of the estimated AT force strongly depends on the reliability of the collected experimental data (anatomical landmarks identification and skin artefact in the first place ${ }^{367-369}$ ) and on the chosen musculoskeletal model (inertial parameters and musculoskeletal geometries are based on generic models scaled on the subject's proportions) ${ }^{370}$. For this latter reason, the scientific community has been recently focusing on the availability of imaging techniques to assess subject-specific musculoskeletal geometries simultaneously to motion data collection to estimate ankle dynamics ${ }^{371-373}$. 
Table XIV. Answer n. 11: Tendon transfer.

\begin{tabular}{|c|c|c|c|c|c|c|}
\hline Author & Year & Type of study & $\begin{array}{l}\text { Level of } \\
\text { evidence }\end{array}$ & $\begin{array}{l}\text { N. of } \\
\text { patients }\end{array}$ & $\begin{array}{l}\text { Follow-up } \\
\text { (months) }\end{array}$ & Type of surgery \\
\hline Maffulli N, et al. ${ }^{171}$ & 2005 & Cohort study & III & 21 & 24 & Free autologous gracilis tendon graf \\
\hline El Shewy MT, et al. ${ }^{172}$ & 2009 & Case series & IV & 11 & 90 & $\begin{array}{l}\text { Intratendinosus flaps from } \\
\text { gastrocnemius-soleus complex }\end{array}$ \\
\hline Maffulli N, et al. ${ }^{173}$ & 2010 & Case series & IV & 32 & 72 & Peroneus brevis tendon transfer \\
\hline Us AK, et al. ${ }^{174}$ & 1997 & Case series & IV & 6 & 16 & $\begin{array}{l}\text { V-Y gastrocnemius recession, end } \\
\text { to end anastomosis and } \\
\text { gastrocnemius aponeurotic flap }\end{array}$ \\
\hline Kissel CG, et al. ${ }^{175}$ & 1994 & Case series & IV & 4 & 38 & $\begin{array}{l}\mathrm{V}-\mathrm{Y} \text { gastrocnemius recession, end } \\
\text { to end anastomosis and plantaris } \\
\text { tendon weaving }\end{array}$ \\
\hline Esenyel CZ, et al. ${ }^{176}$ & 2014 & Case series & IV & 10 & 43,2 & $\begin{array}{l}\text { Turndown gastocnemius-soleus } \\
\text { fascial flap }\end{array}$ \\
\hline Guclu B, et al. ${ }^{177}$ & 2016 & $\begin{array}{l}\text { Retrospective } \\
\text { comparative } \\
\text { study }\end{array}$ & III & 17 & 195 & $\begin{array}{l}\text { V-Y tendon plasty with fascia } \\
\text { turndown }\end{array}$ \\
\hline Rush JH, et al. ${ }^{178}$ & 1980 & Case series & IV & 5 & $18-24$ & $\begin{array}{l}\text { Gastrocnemius-soleus aponeurotic } \\
\text { flap turndown }\end{array}$ \\
\hline Wapner KL, et al. 179 & 1993 & Case series & IV & 7 & 17 & $\begin{array}{l}\text { Flexor hallucis longus tendon } \\
\text { transfer }\end{array}$ \\
\hline Pintore E, et al. ${ }^{180}$ & 2001 & $\begin{array}{l}\text { Comparative } \\
\text { (A vs C) }\end{array}$ & II & 59 & 53 & Peroneus brevis tendon transfer \\
\hline Ademoglu $\mathrm{Y}$, et al. ${ }^{181}$ & 2001 & Case series & IV & 4 & 39,2 & Peroneus brevis tendon transfer \\
\hline Wong MW, et al. ${ }^{182}$ & 2005 & Case series & IV & 5 & 28,8 & $\begin{array}{l}\text { Flexor hallucis longus tendon } \\
\text { transfer }\end{array}$ \\
\hline Elias I, et al. ${ }^{183}$ & 2007 & Case series & IV & 15 & 26,5 & $\begin{array}{l}\text { V-Y leghtening and flexor hallucis } \\
\text { longus tendon transfer }\end{array}$ \\
\hline Mahajan $\mathrm{RH}$, et al. ${ }^{184}$ & 2009 & Case series & IV & 36 & 12 & $\begin{array}{l}\text { Flexor hallucis longus tendon } \\
\text { transfer }\end{array}$ \\
\hline Maffulli N, et al. ${ }^{185}$ & 2012 & Case series & IV & 16 & 185 & Peroneus brevis tendon transfer \\
\hline Rahm S, et al. ${ }^{186}$ & 2013 & $\begin{array}{l}\text { Retrospective } \\
\text { comparative } \\
\text { series } \\
\text { (tt vs to) }\end{array}$ & III & 40 & 73-35 & $\begin{array}{l}\text { Flexor hallucis longus tendon } \\
\text { transfer }\end{array}$ \\
\hline $\begin{array}{l}\text { Dumbre Patil SSD, } \\
\text { et al. }{ }^{187}\end{array}$ & 2014 & Case series & IV & 35 & 30,7 & Semitendinosus tendon autograft \\
\hline Singh A, et al. ${ }^{188}$ & 2014 & Case series & IV & 22 & 12 & $\begin{array}{l}\text { Peroneus brevis tendon } \\
\text { augumentation }\end{array}$ \\
\hline Khiami F, et al. ${ }^{189}$ & 2013 & Retrospective & IV & 23 & 24,5 & $\begin{array}{l}\text { Free sural triceps aponeurosis } \\
\text { transfer }\end{array}$ \\
\hline Maffulli N, et al. ${ }^{190}$ & 2015 & Case series & IV & 17 & 54 & Peroneus brevis tendon transfer \\
\hline Ahmad J, et al. ${ }^{191}$ & 2016 & Case series & IV & 32 & 62,3 & $\begin{array}{l}\text { Flexor hallucis longus tendon } \\
\text { transfer }\end{array}$ \\
\hline Gedam PN, et al. ${ }^{192}$ & 2016 & $\begin{array}{l}\text { Retrospective } \\
\text { comparative }\end{array}$ & III & 14 & 30,1 & $\begin{array}{l}\text { Central turndown flap with free } \\
\text { semitendinosus tendon graft }\end{array}$ \\
\hline Maffulli N, et al. ${ }^{193}$ & 2013 & Case series & IV & 26 & 31,4 & Free semitendinosus tendon graft \\
\hline
\end{tabular}


Continued from Table XIV.

\begin{tabular}{|c|c|c|c|c|c|c|}
\hline Author & Year & Type of study & $\begin{array}{l}\text { Level of } \\
\text { evidence }\end{array}$ & $\begin{array}{l}\text { N. of } \\
\text { patients }\end{array}$ & $\begin{array}{l}\text { Follow-up } \\
\text { (months) }\end{array}$ & Type of surgery \\
\hline Mann RA, et al. ${ }^{194}$ & 1991 & Case series & IV & 7 & 39 & Flexor digitorum longus tendon graft \\
\hline Elgohary HEA, et al. ${ }^{195}$ & 2016 & Case series & IV & 19 & 29 & $\begin{array}{l}\text { Flexor hallucis longus tendon } \\
\text { transfer }\end{array}$ \\
\hline Miao X, et al. ${ }^{196}$ & 2016 & Case series & IV & 32 & 32,2 & $\begin{array}{l}\text { Flexor hallucis longus tendon } \\
\text { transfer }\end{array}$ \\
\hline Maffulli N, et al. ${ }^{197}$ & 2015 & Cohort study & III & 21 & 54 & Peroneus brevis tendon transfer \\
\hline Yeoman TF, et al. ${ }^{198}$ & 2012 & Case series & IV & 11 & 6 & $\begin{array}{l}\text { Flexor hallucis longus tendon } \\
\text { transfer }\end{array}$ \\
\hline Park YS, et al. ${ }^{199}$ & 2012 & $\begin{array}{l}\text { Retrospective } \\
\text { (VY vs G vs } \\
\text { FHL) }\end{array}$ & III & 12 & 36,2 & $\begin{array}{l}\text { V-Y advancement, gastrocnemius } \\
\text { fascial turndown flap, FHL tendon } \\
\text { transfer }\end{array}$ \\
\hline Sarzaeem MM, et al.200 & 2012 & Case series & IV & 11 & 25 & Free semitendinosus tendon graft \\
\hline Zheng L, et al.201 & 2011 & Case series & IV & 10 & $8-48$ & Peroneus brevis tendon transfer \\
\hline Wegrzyn J, et al.202 & 2010 & Case series & IV & 11 & 79 & $\begin{array}{l}\text { Flexor hallucis longus tendon } \\
\text { transfer }\end{array}$ \\
\hline Lee KB, et al. 203 & 2009 & Case series & IV & 3 & $18-24$ & $\begin{array}{l}\text { Flexor hallucis longus tendon } \\
\text { transfer }\end{array}$ \\
\hline Fotiadis $\mathrm{E}$, et al.204 & 2008 & Case series & IV & 9 & 44 & $\begin{array}{l}\text { Plantaris tendon transfer and } \\
\text { Duthie's biological repair }\end{array}$ \\
\hline Lui TH, et al. 205 & 2007 & Case series & IV & 3 & 15 & $\begin{array}{l}\text { Flexor hallucis longus tendon } \\
\text { transfer }\end{array}$ \\
\hline Miskulin M, et al.206 & 2005 & Case series & IV & 5 & 12 & $\begin{array}{l}\text { Peroneus brevis tendon transfer and } \\
\text { plantaris tendon Augumentation }\end{array}$ \\
\hline Dalal RB, et al. 207 & 2003 & Case series & IV & 2 & $\begin{array}{l}\text { Not } \\
\text { reported }\end{array}$ & $\begin{array}{l}\text { Flexor hallucis longus tendon } \\
\text { transfer }\end{array}$ \\
\hline Seker A, et al. ${ }^{208}$ & 2016 & Case series & IV & 21 & 145,3 & Gastrocnemius fascial flap \\
\hline Lapidus LJ, et al. ${ }^{209}$ & 2012 & Case series & IV & 9 & 60 & Achilles tendon island flap \\
\hline Takao M, et al. ${ }^{210}$ & 2003 & Case series & IV & 10 & $26-192$ & Gastrocnemius fascial flap \\
\hline Ozan F, et al. 211 & 2017 & $\begin{array}{l}\text { Comparative } \\
\text { (V vs L) }\end{array}$ & II & 15 & 19.6 & Lindholm and Vulpius tecnique \\
\hline Sanada T, et al. ${ }^{212}$ & 2017 & Case series & IV & 56 & 6 & Free gastrocnemius aponeurotic flap \\
\hline Maffulli N, et al. ${ }^{213}$ & 2014 & Case series & IV & 28 & 24 & Semitendinosus tendon autograft \\
\hline El Shazly O, et al. ${ }^{214}$ & 2014 & Case series & IV & 15 & 27 & Free hamstring tendon autograft \\
\hline Tay D, et al. ${ }^{215}$ & 2010 & Case series & IV & 6 & 24 & Turndown tendon flaps \\
\hline $\begin{array}{l}\text { Nilsson-Helander K, } \\
\text { et al. }{ }^{216}\end{array}$ & 2008 & Case series & IV & 28 & 29 & Free gastrocnemius aponeurotic flap \\
\hline Tawari AA, et al. ${ }^{217}$ & 2013 & Case series & IV & 20 & 18 & Peroneus brevis tendon transfer \\
\hline Oksanen MM, et al. ${ }^{218}$ & 2014 & Case series & IV & 7 & 27 & $\begin{array}{l}\text { Flexor hallucis longus tendon } \\
\text { transfer }\end{array}$ \\
\hline
\end{tabular}

A, acute rupture; C, chronic rupture; tt, transtendineous technique; to, transosseus technique; VY, V-Y plasty; G, gastrocnemius fascial flap; "FHL", flexor hallucis longus tendon transfer; V, Vulpius tecnique; L, Lindholm tecnique. 
Table XV. Answer n. 13: Rehabilitation protocol after acute ruptures. Open Surgery.

\begin{tabular}{|c|c|c|c|c|c|c|}
\hline Author & Year & $\begin{array}{l}\text { Type of } \\
\text { study }\end{array}$ & $\begin{array}{l}\text { Level of } \\
\text { evidence }\end{array}$ & $\begin{array}{l}\text { N. of patients } \\
\text { ( } P \text { vs O) }\end{array}$ & $\begin{array}{l}\text { Follow-up } \\
\text { (months) }\end{array}$ & $\begin{array}{l}\text { Treatment } \\
\text { groups }\end{array}$ \\
\hline $\begin{array}{l}\text { Valkering } \mathrm{KP} \text {, } \\
\text { et al. } 239\end{array}$ & 2017 & $\mathrm{RCT}$ & II & 56 (27 vs 29) & 12 & $\begin{array}{l}\text { - Mobilized and FWB group } \\
\text { - Immobilized and NWB group }\end{array}$ \\
\hline Lantto I, et al. ${ }^{240}$ & 2015 & RCT & 1 & 50 (25 vs 25) & 132 & $\begin{array}{l}\text { - Early mobilization group } \\
\text { - Immobilization in tension } \\
\text { group }\end{array}$ \\
\hline Suchak AA, et al.241 & 2008 & $\mathrm{RCT}$ & 1 & 110 (55 vs 55) & 6 & $\begin{array}{l}\text { - Weight-Bearing as tolerated } \\
\text { Group } \\
\text { - NBW group }\end{array}$ \\
\hline Costa ML, et al.242 & 2006 & RCT & II & 48 (23 vs 25) & 12 & $\begin{array}{l}\text { - Treatment Group } \\
\text { - Control Group }\end{array}$ \\
\hline Maffulli N, et al. ${ }^{91}$ & 2003 & $\begin{array}{l}\text { Case-control } \\
\text { study }\end{array}$ & III & 53 (26 vs 27) & 4.5 & $\begin{array}{l}\text { - Group } 1 \\
\text { - Group } 2\end{array}$ \\
\hline Kangas J, et al. ${ }^{243}$ & 2003 & RCT & II & 50 (25 vs 25) & 15 & $\begin{array}{l}\text { - Group I } \\
\text { - Group II }\end{array}$ \\
\hline $\begin{array}{l}\text { Kerkhoffs GM, } \\
\text { et al. }{ }^{244}\end{array}$ & 2002 & $\mathrm{RCT}$ & II & 39 (23 vs 16) & 80 & $\begin{array}{l}\text { - Cast group } \\
\text { - Wrap group }\end{array}$ \\
\hline $\begin{array}{l}\text { Mortensen HM, } \\
\text { et al. } 245\end{array}$ & 1999 & $\mathrm{RCT}$ & II & 61 (31 vs 30) & 24 & $\begin{array}{l}\text { - Early Motion group } \\
\text { - Cast group }\end{array}$ \\
\hline
\end{tabular}

FBW, complete weight bearing; NBW, no weight bearing.

Table XVI. Answer n. 13: Rehabilitation protocol after acute ruptures. Minimally invasive or percutaneous surgery.

\begin{tabular}{l|l|l|l|l|l|l}
\hline Author & Year & Type of study & $\begin{array}{l}\text { Level of } \\
\text { evidence }\end{array}$ & $\begin{array}{l}\text { N. of patients } \\
\text { (P vs O) }\end{array}$ & $\begin{array}{l}\text { Follow-up } \\
\text { (months) }\end{array}$ & $\begin{array}{l}\text { Treatment } \\
\text { Groups }\end{array}$ \\
\hline $\begin{array}{l}\text { De la Fuente C, } \\
\text { et al.246 }\end{array}$ & 2016 & RCT & II & $38(19$ vs 19) & 3 & $\begin{array}{l}\text { - Conventional group } \\
\text { Aggressive group }\end{array}$ \\
\hline $\begin{array}{l}\text { Groetelaers RP, } \\
\text { et al.247 }\end{array}$ & 2014 & RCT & II & $60(32$ vs 28) & 12 & $\begin{array}{l}\text { Functional group } \\
\text { Immobilization } \\
\text { group }\end{array}$ \\
\hline Majewski M, et al.248 & 2008 & Case-control study & III & $28(14$ vs 14) & 12 & $\begin{array}{l}\text { - Cast group } \\
\text { Shoe group }\end{array}$ \\
\hline
\end{tabular}

Prediction of AT force during terrestrial locomotion: difference with respect to methods, to the computational approach and to the adopted musculoskeletal model in Table XX.

Answer n. 18: Acute ruptures in the childhood in Table XXI.

\section{Project management}

I.S.Mu.L.T. - Italian Society of Muscles Ligaments \& Tendons.

\section{Coordinator}

Francesco Oliva

Department of Orthopaedics and Traumatology, University of Rome "Tor Vergata", Italy. 
Table XVII Answer n. 15: Nutracenticals. Clinical studies about the characteristics in the use of nutraceuticals for therapy of tendinopathies.

\begin{tabular}{|c|c|c|c|c|}
\hline Author/Year & Pathology & $\begin{array}{l}\text { Type of nutraceutical } \\
\text { and composition }\end{array}$ & $\begin{array}{l}\text { Type of } \\
\text { study/N. of } \\
\text { patients }\end{array}$ & Groups compared \\
\hline $\begin{array}{l}\text { Notarnicola A, } \\
\text { et al. } 20122^{274}\end{array}$ & $\begin{array}{l}\text { Insertional Achilles } \\
\text { tendinopathy }\end{array}$ & $\begin{array}{l}\text { Tenosan® } \\
\text { (L-arginine-a- } \\
\text { ketoglutarate, } \\
\text { methylsulfonylmethane, } \\
\text { type I hydrolazate } \\
\text { collagen, Vinitrox }{ }^{\mathrm{TM}}, \\
\text { bromelain, vitamin C) }\end{array}$ & $\begin{array}{l}\text { RCT (placebo) } \\
\text { g-t: } 32 \\
\text { g-c: } 32>26\end{array}$ & $\begin{array}{l}\text { g-t: ESWT + Tenosan } \AA \\
\text { g-c: EWTS + placebo } \\
\text { Dosage: } 2 \text { bags/day for } 60 \text { days before } \\
\text { main meal }\end{array}$ \\
\hline $\begin{array}{l}\text { Balius R, et al. } \\
2016^{275}\end{array}$ & $\begin{array}{l}\text { Non-insertional } \\
\text { painful Achilles } \\
\text { tendinopathy }\end{array}$ & $\begin{array}{l}\text { Tendoactive }{ }^{\circledR} \\
\text { (mucopolysaccharids, } \\
\text { type I collagen, vitamin C) }\end{array}$ & $\begin{array}{l}\text { RCT (no } \\
\text { placebo) } \\
\text { g-t 1: } 19>17 \\
\text { g-t } 2: .20 \\
\text { g-c: } 19->18\end{array}$ & $\begin{array}{l}\text {-t 1: EC + Tendoactive }{ }^{\circledR} \\
\text { g-t 2: PS + Tendoactive }{ }^{\circledR} \\
\text { g-c: EC } \\
\text { Dosage: } 3 \text { capsules/day for } 12 \text { weeks }\end{array}$ \\
\hline $\begin{array}{l}\text { Hai-Binh B, } \\
\text { et al. } 2014276\end{array}$ & $\begin{array}{l}\text { Various } \\
\text { tendinopathies } \\
\text { (Achilles tendon, } \\
\text { sopraspinatus, lateral } \\
\text { epicondyle, plantar } \\
\text { fascitis) }\end{array}$ & $\begin{array}{l}\text { Tendoactive }{ }^{\circledR} \\
\text { (mucopolysaccharids, } \\
\text { type I collagen, vitamin C) }\end{array}$ & $\begin{array}{l}\text { RCT (placebo) } \\
\text { g-t: } 30 \\
\text { g-c: } 30\end{array}$ & $\begin{array}{l}\text { g-t: Tendoactive }{ }^{\circledR} \\
\text { g-c: placebo } \\
\text { Dosage: } 2 \text { capsules/day for } 90 \text { days }\end{array}$ \\
\hline $\begin{array}{l}\text { Nadal F, et al. } \\
2009^{277}\end{array}$ & $\begin{array}{l}\text { Various } \\
\text { tendinopathies } \\
\text { (Achilles tendon, } \\
\text { sopraspinatus, lateral } \\
\text { epicondyle, plantar } \\
\text { fascitis) }\end{array}$ & $\begin{array}{l}\text { Tendoactive } \AA \\
\text { (mucopolysaccharids, } \\
\text { type I collagen, vitamin C) }\end{array}$ & $\begin{array}{l}\text { RCT (no } \\
\text { placebo) } \\
\text { g-t: } 10 \\
\text { g-c: } 10\end{array}$ & $\begin{array}{l}\text { g-t: rehabilitation + Tendoactive }{ }^{\circledR} \\
\text { g-c: rehabilitation } \\
\text { Dosage: } 2.16 \mathrm{~g} / \text { day for } 3 \text { months }\end{array}$ \\
\hline $\begin{array}{l}\text { Arquer A, et al. } \\
2014^{278}\end{array}$ & $\begin{array}{l}\text { Various } \\
\text { tendinopathies } \\
\text { (Achilles tendon } \\
n=32 \text {, patellat tendon } \\
n=32 \text {, lateral } \\
\text { epicondyle } n=34 \text { ) }\end{array}$ & $\begin{array}{l}\text { Tendoactive }{ }^{\circledR} \\
\text { (mucopolysaccharids, } \\
\text { type I collagen, vitamin C) }\end{array}$ & $\begin{array}{l}\text { Perspective } \\
\text { not controlled } \\
\text { explorative } \\
\text { study of phase } \\
\text { IV } n=98->70\end{array}$ & Dosage: 3 capsules/day for 90 days \\
\hline $\begin{array}{l}\text { Mavrogenis S, } \\
\text { et al. } 2004279\end{array}$ & $\begin{array}{l}\text { Chronic tendon } \\
\text { disorders }{ }^{\star}\end{array}$ & $\begin{array}{l}\text { Bio-Sport }{ }^{\circledR} \\
\text { Essential fatty acids } \\
\text { (EPA, DHA, GLA) + } \\
\text { antioxidants (selenium, } \\
\text { zinc, vitamin A, vitamin } \\
\text { B6, vitamin C, vitamin E) }\end{array}$ & $\begin{array}{l}\text { RCT (placebo, } \\
\text { double } \\
\text { blinded) on } \\
\text { athletes } \\
\text { g-t:. } 20->17 \\
\text { g-c:. } 20->14\end{array}$ & $\begin{array}{l}\text { g-t: ultrasounds + supplements } \\
\text { c-g: ultrasounds + placebo } \\
\text { Dosage: } 8 \text { capsules/day essential fatty } \\
\text { acids }+1 \text { antioxidants for } 32 \text { days }\end{array}$ \\
\hline
\end{tabular}

EC, eccentric exercise; PS, passive stretching; g-t, treated group; g-c, control group; ESWT, Extracorporeal shock wave therapy; EPA, eicosapentaenoic acid; DHA, docosahexaenoic acid; GLA, gamma-linolenic acid; *Chronic tendon disorders. NB: Balius - Hai-Bin - Arquer - Nadal: same supplement (Tendoactive®).

\section{Overseeing group}

Nicola Maffulli, Pasquale Farsetti, Calogero Foti, Milena Fini, Biagio Moretti, Pietro Ruggieri, Umberto Tarantino, Maria Chiara Vulpiani.

\section{Group of experts}

Carlo Biz, Roberto Buda, Daniela Buonocore, Vincenzo De Luna, Luigi Di Lorenzo, Bernardo Innocenti, Alessio Giai Via, Antonio Frizziero, Alfonso Maria Forte, Asmaa Mahmoud, Angelo De Carli, Johnny
Padulo, Pietro Picerno, Francesca Veronesi, Mario Vetrano, Marcello Zappia.

\section{Group of preparation and evaluation of the literature}

Matteo Baldassarri, Gabriele Bernardi, Michela Bossa, Vito Chianca, Anna Collina, Imma Di Lanno, Francesco Di Pietto, Maurizia Dossena, Ilaria Fantoni, Paolo Finotti, Edoardo Gaj, Carlotta Galeone, Jacopo Gamberini, Monica Gasparini, Domenico Lupariello, 
Table XVIII. Answer n. 15: Nutracenticals. Clinical studies about the use of nutraceuticals for therapy of tendinopathies.

\begin{tabular}{|c|c|c|c|}
\hline Author/Year & Outcome assessments & Follow-up & Results \\
\hline $\begin{array}{l}\text { Notarnicola A, } \\
\text { et al. } 2012^{274}\end{array}$ & $\begin{array}{l}\text { Tenosan }{ }^{\circledR} \text { efficacy combined } \\
\text { with shock waves in insertional } \\
\text { Achilles tendinopathy } \\
\text { management } \\
\text { Primary endpoints (clinical and } \\
\text { functional effects) } \\
\text { VAS scorea } \\
\text { Ankle-Hindfoot Scaleb (pain, } \\
\text { function, alignment) } \\
\text { Roles and Maudsley score } \\
\text { (subjective improvement } \\
\text { perception)c } \\
\\
\text { Secondary endpoint } \\
\text { (neoangiogenesis) } \\
\text { Tissue oximetry }\end{array}$ & 2 and 6 months & $\begin{array}{l}\text { VAS score significantly lower in both groups } \\
\text { during the study. At } 6 \text { months, VAS score } \\
\text { significantly lower in the group with combined } \\
\text { treatment (average score: } 2.0 \text { vs } 2.9, p=0.04 \text { ), } \\
\text { although difference }<2 \text { points (threshold clinically } \\
\text { significantly) } \\
\text { Ankle-Hindfoot Scale significantly improved } \\
\text { scores only in the group with combined } \\
\text { treatment during the study. At } 2 \text { and } 6 \text { months, } \\
\text { improved scores in the group with combined } \\
\text { treatment (average at } 6 \text { months: } 92.4 \text { vs } 76.5 \text {, } \\
p=0.0002 \text { ) } \\
\text { At } 2 \text { and } 6 \text { months, improved scores (lower) in } \\
\text { Roles and Maudsley score in the group with } \\
\text { combined treatment (average at } 6 \text { months: } 1.5 \\
v s 2.3, p<0.0001 \text { ) } \\
\text { Significantly lower scores at oximetry in both } \\
\text { groups due during the study; only at } 6 \text { months } \\
\text { significantly difference between the two groups } \\
\text { in favor of the group with combined treatment } \\
\text { (average } 60.2 \text { vs } 66.0, p=0.007 \text { ) }\end{array}$ \\
\hline $\begin{array}{l}\text { Balius R, et al. } \\
2016275\end{array}$ & $\begin{array}{l}\text { Tendoactive }{ }^{\circledR} \text { efficacy combined } \\
\text { with eccentric physical exercise } \\
\text { to improve non-insertional painful } \\
\text { Achilles tendinopathy symptoms } \\
\text { Primary endpoint } \\
\text { VISA-A questionnaire scored } \\
\text { (function and pain) } \\
\text { Secondary endpoints } \\
\text { VAS score for paina at rest and } \\
\text { during activity } \\
\text { Tendon thickness (ultrasound) }\end{array}$ & 6 and 12 weeks & 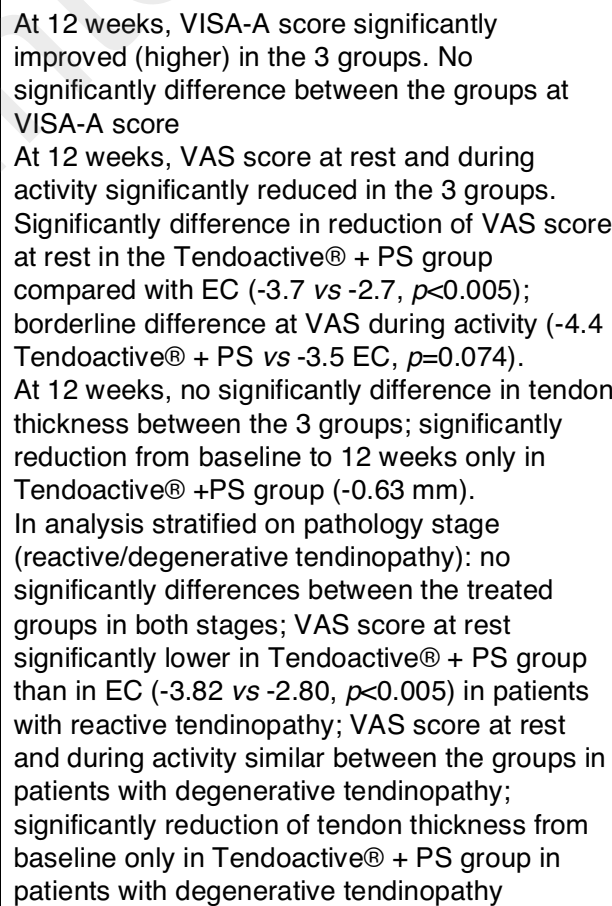 \\
\hline $\begin{array}{l}\text { Hai-Binh B, et al. } \\
2014276\end{array}$ & $\begin{array}{l}\text { Tendoactive® efficacy and safety } \\
\text { in management of different } \\
\text { tendinopathies } \\
\text { Swelling, heat, redness (clinical } \\
\text { evaluation) } \\
\text { VAS score for paina } \\
\text { Tendinopathy (ultrasound) }\end{array}$ & $\begin{array}{l}\text { Monthly during } \\
\text { the study ( } 90 \\
\text { days) }\end{array}$ & $\begin{array}{l}\text { Progressively reduction of presence of swelling, } \\
\text { heat, redness in both groups; lower in the } \\
\text { experimental group at every monthly control } \\
\text { VAS score significantly reduced in both groups } \\
\text { during the study. At } 90 \text { days, VAS score } \\
\text { significantly lower in the experimental group } \\
\text { (average: } 2.5 \text { vs } 3.2, p<0.05 \text { ) } \\
\text { At } 90 \text { days, no patient in the experimental group } \\
\text { has diagnosis of tendinopathy (\% placebo group } \\
\text { not reported by Authors) }\end{array}$ \\
\hline
\end{tabular}


Continued from Table XVIII.

\begin{tabular}{|c|c|c|c|}
\hline Author/Year & Outcome assessments & Follow-up & Results \\
\hline $\begin{array}{l}\text { Nadal F, et al. } \\
2009277\end{array}$ & $\begin{array}{l}\text { Tendoactive }{ }^{\circledR} \text { efficacy in } \\
\text { treatment of different } \\
\text { tendinopathies } \\
\text { Pain } \\
\text { SF36 (Quality of life) } \\
\text { Functional evaluation by } \\
\text { physiotherapist }\end{array}$ & $\begin{array}{l}1,2 \text { and } 3 \\
\text { months }\end{array}$ & $\begin{array}{l}\text { Significantly reduction of pain in the } \\
\text { experimental group for every pathology, except } \\
\text { for epicondylitis } \\
\text { Improved of SF } 36 \text { in every group of pathology } \\
\text { At } 3 \text { months significantly improvement of } \\
\text { function for every tendinopathies. } \\
\text { (Results of placebo group not reported by } \\
\text { Authors) }\end{array}$ \\
\hline $\begin{array}{l}\text { Arquer A, et al. } \\
2014278\end{array}$ & $\begin{array}{l}\text { Tendoactive }{ }^{\circledR} \text { efficacy and safety } \\
\text { in treatment of different } \\
\text { tendinopathies } \\
\text { VAS score for paina at rest and } \\
\text { during activity } \\
\text { Function (VISA-A score for } \\
\text { Achilles tendon, VISA-P for } \\
\text { patellar tendon, PRTEE for } \\
\text { elbow) } \\
\text { Ultrasound structural parameters } \\
\text { (tendon thickness, effacement of } \\
\text { the paratenon, eteroechogenicity } \\
\text { and hypoechogenicity levels, } \\
\text { neovascularization) }\end{array}$ & $30,60,90$ days & $\begin{array}{l}3 \text { groups based on pathology: Achilles } \\
\text { tendinopathy (AQ), patellar tendinopathy (RO), } \\
\text { lateral epicondylitis (EPI) } \\
\text { Significantly reduction of VAS score at rest and } \\
\text { during activity in the } 3 \text { groups at } 30,60 \text { and } 90 \\
\text { days. At } 90 \text { days, compared to baseline, the pain } \\
\text { at rest is reduced of } 80 \% \text { in } A Q, \text { of } 71 \% \text { in RO } \\
\text { and of } 91 \% \text { in } \mathrm{EPI} \text {; pain during activity reduced } \\
\text { of } 82 \% \text { in } A Q, 73 \% \text { in RO and } 81 \% \text { in EPI } \\
\text { Significantly improvement of VISA-A, VISA-P } \\
\text { and PRTEE at } 30,60 \text { and } 90 \text { days. At } 90 \text { days, } \\
\text { compared to baseline, improvement of } 38 \% \text {, } \\
46 \% \text { and } 77 \% \text { in AQ, RO, and EPI } \\
\text { Significantly reduction in tendon thickness in the } \\
3 \text { groups (at } 90 \text { days: } 12 \% \text { in AQ, } 10 \% \text { in RO } \\
\text { and } 20 \% \text { in } \mathrm{EPI).} \mathrm{In} \mathrm{EPI} \mathrm{group} \mathrm{reduction} \mathrm{during} \\
\text { all period; in AQ and RO groups reduction at } 60 \\
\text { days, after stable at } 90 \\
\text { Improved of all structural parameters in the } 3 \\
\text { groups. Paratenon blurred and levels of } \\
\text { heteroechogenicity and hypoechogenicity } \\
\text { significantly improved in AQ and EPI; level of } \\
\text { hypoechogenicity not significantly improbe in RO } \\
\text { group ( } p=0.07 \text { ); neovascularization significantly } \\
\text { improbe only in EPI group }\end{array}$ \\
\hline $\begin{array}{l}\text { Mavrogenis S, } \\
\text { et al. } 2004279\end{array}$ & $\begin{array}{l}\text { Efficacy of suppluement } \\
\text { combined with phyisiotherapy in } \\
\text { treatment of chronic } \\
\text { tendinopathies in athletes } \\
\text { Primary endpoints } \\
\text { VAS score for pain } \\
\text { VAS score for pain a after } \\
\text { isometric test } \\
\text { Secondary endpoints } \\
\text { Physical activity }\end{array}$ & $\begin{array}{l}8,16,24 \text { and } 32 \\
\text { days }\end{array}$ & $\begin{array}{l}\text { VAS score lower duraing the study in both } \\
\text { groups. At } 32 \text { days, statistically significantly } \\
\text { difference between the groups in favor of } \\
\text { experimental group ( } p<0.001 \text { ) (VAS score } \\
\text { reduced } 99 \% \text { in experimental group and } 31 \% \text { in } \\
\text { control group). Similar results of VAS score after } \\
\text { isometric test: at } 32 \text { days, score significantly } \\
\text { lower ( } p<0.001 \text { ) in experimental group (VAS } \\
\text { score reduced } 99 \% \text { in experimental group and } \\
37 \% \text { control group) } \\
\text { At } 32 \text { days, improved sport activity compared to } \\
\text { basal ( } 53 \% \text { in experimental group and } 11 \% \\
\text { control group } \\
\text { No adverse events in both groups }\end{array}$ \\
\hline
\end{tabular}

EC, eccentric exercise; PRTEE, Patient-Rated Tennis Elbow Evaluation; PS, passive stretching; SF, short-form; VAS, visual analog scale; VISA-A, Victorian Institute of Sports Assessment-Achilles; VISA-P, Victorian Institute of Sports AssessmentPatella.

a VAS: range 0-10 (10=severe pain; $0=$ no pain).

b Ankle-Hindfoot Scale: range 0-100 (100=no pain, no limitations, good alignment; $0=$ severe pain, severe limitations, severe misalignment).

c Roles and Maudsley score: range 1-4 (4=no satisfaction or low satisfaction of the treatment, 1=good satisfaction of the treatment).

d VISA-A questionnaire: range 0-100 (higher scores for better functionality and lower pain). 
Table XIX. Answer n. 16: Return to sport.

\begin{tabular}{|c|c|c|c|c|}
\hline Author & N. of patients & Groups & $\%$ return to sport & Variables analyzed \\
\hline Ahmad J, et al. ${ }^{280}$ & 30 & 1 & NR & FAAM Sports Subscale \\
\hline Aktas S, et al. ${ }^{142}$ & 40 & 1 & 87 & AOFAS \\
\hline Aktas S, et al. ${ }^{121}$ & 30 & 1 & 86.9 & AOFAS \\
\hline Al-Mouazzen L, et al. ${ }^{281}$ & 30 & 1 & NR & ATRS \\
\hline Amin $\mathrm{NH}$, et al. ${ }^{282}$ & 18 & 1 & 61 & NBA Player Efficiency Rating \\
\hline Amlang $\mathrm{MH}$, et al. ${ }^{283}$ & 39 & 1 & 51 & AOFAS \\
\hline Ateschrang A, et al. ${ }^{284}$ & 104 & 1 & 64.4 & Thermann Score \\
\hline Barfod KW, et al. 271 & 56 & 1 & 18.6 & ATRS \\
\hline Bassi JL, et al.285 & 11 & 2 & 100 & \\
\hline Bevoni R, et al. ${ }^{286}$ & 66 & 2 & 98.5 & AOFAS, Leppilahti \\
\hline Bostick GP, et al. ${ }^{287}$ & 84 & 2 & 84 & \\
\hline Boyden EM, et al. ${ }^{288}$ & 10 & 2 & 80 & Boyden Scale \\
\hline Carmont MR, et al. 289 & 26 & 1 & 61 & Tegner Score \\
\hline Ceccarelli F, et al. .290 & 24 & 1 & 91.7 & AOFAS \\
\hline Chandrakant V, et al. ${ }^{291}$ & 52 & 1 & 90 & AOFAS \\
\hline Chen Z, et al. ${ }^{292}$ & 76 & 1 & 100 & \\
\hline Chiu $\mathrm{CH}$, et al. 86 & 19 & 1 & 94.7 & Tegner Score, AOFAS \\
\hline Coutts A, et al.293 & 25 & 1 & 80 & \\
\hline Cretnik A, et al. ${ }^{141}$ & 237 & 1 & 72.1 & AOFAS \\
\hline Cretnik A, et al. ${ }^{294}$ & 116 & 1 & 96 & AOFAS \\
\hline Cretnik A, et al. ${ }^{295}$ & 13 & 2 & 100 & AOFAS \\
\hline De Carli A, et al. ${ }^{154}$ & 20 & 1 & 70.5 & \\
\hline Demirel M, et al.296 & 78 & 1 & 77.1 & \\
\hline Doral MN, ${ }^{297}$ & 32 & 1 & 100 & FAOS, ATRS \\
\hline Eames MHA, et al. ${ }^{298}$ & 32 & 1 & 63 & \\
\hline Feldbrin Z, et al.299 & 14 & 1 & 100 & AOFAS \\
\hline Fernández-Fairén $\mathrm{M}$, et al. ${ }^{300}$ & 29 & 2 & 96.6 & AOFAS \\
\hline Fortis AP, et al. ${ }^{301}$ & 20 & 1 & 100 & \\
\hline Garabito A, et al. ${ }^{302}$ & 49 & 1 & 89.8 & AOFAS \\
\hline
\end{tabular}


Continued from Table XIX.

\begin{tabular}{|c|c|c|c|c|}
\hline Garrido IM, et al. ${ }^{303}$ & 18 & 2 & 72.2 & AOFAS \\
\hline Goren D, et al. ${ }^{149}$ & 20 & 1 & 55 & \\
\hline Gorschewsky O, et al. ${ }^{304}$ & 20 & 2 & 100 & \\
\hline Gorschewsky O, et al.305 & 66 & 2 & 100 & \\
\hline Groetelaers RP, et al. ${ }^{247}$ & 55 & 1 & 39 & ARPS \\
\hline Guillo S, et al. ${ }^{306}$ & 23 & 1 & 80 & ATRS, Boyden Scale \\
\hline Halasi T, et al. ${ }^{307}$ & 144 & 1 & 60.7 & \\
\hline Hohendorff B, et al. ${ }^{308}$ & 42 & 1 & 88.6 & Thermann score \\
\hline Hufner TM, et al. ${ }^{309}$ & 125 & 2 & 75.2 & \\
\hline Jaakkola Jl, et al. ${ }^{310}$ & 55 & 2 & 90.9 & AOFAS \\
\hline Jacob KM, et al. ${ }^{311}$ & 46 & 1 & 88.9 & \\
\hline Jallageas R, et al. ${ }^{164}$ & 31 & 1 & 77.5 & AOFAS \\
\hline Jennings AG, et al. ${ }^{312}$ & 30 & 1 & 63.6 & Tennier \\
\hline Josey RA, et al. ${ }^{313}$ & 39 & 1 & 66.7 & AOFAS, Thermann score \\
\hline Jung HG, et al. ${ }^{314}$ & 30 & 2 & 90 & \\
\hline Kakiuchi M, et al. ${ }^{315}$ & 22 & 1 & 45.5 & \\
\hline Karabinas PR, et al. ${ }^{143}$ & 34 & 2 & NR & AOFAS \\
\hline Karkhanis S, et al. ${ }^{316}$ & 107 & 2 & 77 & ATRS \\
\hline Keating JF, et al. ${ }^{135}$ & 80 & 1 & 66.9 & \\
\hline Kelle A, et al. ${ }^{160}$ & 100 & 1 & 80 & \\
\hline Klein EE, et al. ${ }^{161}$ & & 2 & 100 & VISA-A \\
\hline Knobe $\mathrm{M}$, et al. ${ }^{317}$ & 64 & 1 & 36.6 & \\
\hline Kolodziej L, et al. ${ }^{140}$ & 47 & 1 & 46 & \\
\hline Korkmaz M, et al. ${ }^{318}$ & 47 & 1 & NR & PASS \\
\hline Kraus $\mathrm{R}$, et al. ${ }^{319}$ & 36 & 1 & 53 & \\
\hline Labib SA, et al. ${ }^{320}$ & 44 & 1 & 65.71 & \\
\hline Lacoste S, et al. ${ }^{170}$ & 75 & 1 & 63.6 & ATRS, AOFAS \\
\hline Lansdaal JR, et al. ${ }^{321}$ & 163 & 1 & 59.5 & Leppilahti Score \\
\hline Lee DK, ${ }^{322}$ & 11 & 2 & NR & \\
\hline Leppilahti J, et al. ${ }^{323}$ & 101 & 1 & 85.7 & Boyden Scale \\
\hline Macquet AJ, et al. 324 & 87 & 1 & 68.1 & \\
\hline
\end{tabular}


Continued from Table XIX.

\begin{tabular}{|c|c|c|c|c|}
\hline Maffulli N, et al. .91 & 53 & 1 & 92.5 & Modified VISA-A \\
\hline Maffulli N, et al. ${ }^{325}$ & 17 & 2 & 94 & ATRS \\
\hline Maffulli N, et al. ${ }^{326}$ & 27 & 2 & 50 & ATRS \\
\hline Majewski M, et al. 327 & 84 & 1 & 100 & Hannover Achilles tendon score \\
\hline Majewski M, et al.248 & 28 & 1 & 65.2 & Hannover Achilles tendon score \\
\hline Mandelbaum BR, et al. ${ }^{328}$ & 29 & 1 & 100 & $\nabla$ \\
\hline Maniscalco $\mathrm{P}$, et al. ${ }^{329}$ & 7 & 1 & 100 & Mandelbaum and Pavanini evaluation \\
\hline Martinelli B, et al. 330 & 30 & 1 & 100 & \\
\hline McComis GP, et al. ${ }^{331}$ & 15 & 1 & 66 & \\
\hline Metz R, et al. ${ }^{99}$ & 83 & 1 & 72.8 & Leppilahti score \\
\hline Metz R, et al. ${ }^{332}$ & 210 & 1 & 50 & ATRS \\
\hline Miller D, et al. ${ }^{147}$ & 111 & 1 & 88 & \\
\hline Möller $\mathrm{M}$, et al. ${ }^{138}$ & 112 & 1 & 54 & Functional index of lower limbs \\
\hline Mortensen $\mathrm{HN}$, et al. ${ }^{333}$ & 57 & 1 & 70 & \\
\hline Mortensen $\mathrm{HN}$, et al. ${ }^{245}$ & 61 & 1 & 54.1 & \\
\hline Motta $P$, et al. ${ }^{334}$ & 71 & 1 & 28 & \\
\hline Mukundan C, et al. ${ }^{157}$ & 21 & 1 & 95.2 & AOFAS, Leppilahti \\
\hline Nestorson J, et al. ${ }^{335}$ & 25 & 1 & 36 & \\
\hline Nilsson-Helander R, et al. ${ }^{7}$ & 97 & 1 & NR & PAS, ATRS \\
\hline Olsson $\mathrm{N}$, et al. ${ }^{103}$ & 100 & 1 & NR & PAS, ATRS, FAOS \\
\hline Orr J, et al. ${ }^{336}$ & 15 & 2 & 100 & AOFAS \\
\hline Ozsoy M, et al. 337 & 13 & 1 & 92 & AOFAS \\
\hline Pajala A, et al. ${ }^{338}$ & 60 & 1 & 100 & Leppilahti score \\
\hline Parekh SG, et al. ${ }^{339}$ & 31 & 1 & 64.3 & Power rating (pre-surgery and during match) \\
\hline Park HG, et al. ${ }^{340}$ & 14 & 2 & NR & \\
\hline Rajasekar K, et al. ${ }^{341}$ & 35 & 1 & 50 & Accidents questionnaire \\
\hline Rebeccato A, et al. ${ }^{153}$ & 59 & 1 & 98.4 & \\
\hline Rettig AC, et al. ${ }^{342}$ & 89 & 1 & 100 & \\
\hline Richardson LC, et al. ${ }^{343}$ & 30 & 1 & 77 & AOFAS \\
\hline Sánchez M, et al. ${ }^{130}$ & 12 & 1 & 58 & Functional Cincinnati Scale (modified) \\
\hline Schepull T, et al. ${ }^{344}$ & 10 & 1 & 40 & Thermann score \\
\hline
\end{tabular}


Continued from Table XIX.

\begin{tabular}{|c|c|c|c|c|}
\hline Silbernagel KG, et al. ${ }^{345}$ & 8 & 1 & NR & ATRS, FAOS \\
\hline Soldatis J, et al. ${ }^{346}$ & 30 & 1 & 61 & \\
\hline Solveborn S, et al. ${ }^{347}$ & 17 & 1 & 94 & Amer-Lindon Scale \\
\hline Sorrenti S, et al. ${ }^{348}$ & 52 & 2 & 100 & \\
\hline Speck M, et al. ${ }^{349}$ & 20 & 1 & 100 & \\
\hline Stein BE, et al. 350 & 27 & 1 & 92 & 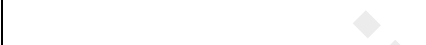 \\
\hline Strauss E, et al. 351 & 54 & 1 & 74 & Boyden Score, AOFAS \\
\hline Suchak AA, et al. 241 & 98 & 2 & 65 & \\
\hline Talbot J, et al. ${ }^{352}$ & 15 & 1 & 66.7 & AOFAS \\
\hline Tenenbaum S, et al. 168 & 29 & 1 & 90 & AOFAS, Boyden score (modified) \\
\hline Troop RL, et al. ${ }^{353}$ & 13 & 1 & 94 & \\
\hline Uchiyama E, et al..$^{354}$ & 100 & 1 & 100 & \\
\hline Valente $\mathrm{M}$, et al. ${ }^{355}$ & 35 & 2 & 100 & AOFAS \\
\hline Wagnon $\mathrm{R}$, et al. ${ }^{356}$ & 57 & 1 & 40 & 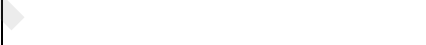 \\
\hline Wallace RGH, et al. 357 & 945 & 1 & 100 & \\
\hline Wallace $\mathrm{RGH}$, et al. ${ }^{358}$ & 140 & 1 & 37 & \\
\hline Young SW, et al. ${ }^{106}$ & 84 & 1 & NR & Leppilahti score, halasi score \\
\hline
\end{tabular}

NR, not reported; AOFAS, American Orthopaedic Foot and Ankle Society Ankle-Hindfoot Score; ARPS, Achilles Rupture Performance Score; ATRS, Achilles Tendon Total Rupture Score; FAAM, Foot and Ankle Ability Measure; FAOS, Foot and Ankle Outcome Score-Ankle and Hindfoot; PAS, Physical Activity Scale; PER, Player Efficiency Rating.

Table XX. Prediction of AT force during terrestrial locomotion: difference with respect to methods, to the computational approach and to the adopted musculoskeletal model.

\begin{tabular}{l|l|l|l}
\hline Authors & Protocol & Task & Results \\
\hline Fukashiro S, et al. ${ }^{655} 1993$ & $\begin{array}{l}\text { Inverse dynamics vs direct } \\
\text { measure }\end{array}$ & Hopping & $\begin{array}{l}\text { diff }=8 \% \\
r=0.99\end{array}$ \\
\hline Kernozek T, et al.362. 2017 & $\begin{array}{l}\text { Conventional vs optimized } \\
\text { inverse dynamics }\end{array}$ & Running & $\begin{array}{l}\text { diff }=4.7 \% \\
(p=0.054)\end{array}$ \\
\hline Gerus P, et al.372. 2012 & $\begin{array}{l}\text { Subject-specific vs generic } \\
\text { musculoskeletal models }\end{array}$ & Hopping/running & diff $=17 \%$ \\
\hline
\end{tabular}

Table XXI. Answer n. 18: Acute ruptures in the childhood.

\begin{tabular}{l|l|l|l|l|l|l}
\hline Author & Year & Type of study & $\begin{array}{l}\text { Level of } \\
\text { evidence }\end{array}$ & $\begin{array}{l}\text { N. of } \\
\text { patients }\end{array}$ & $\begin{array}{l}\text { Follow-up } \\
\text { (months) }\end{array}$ & Type of treatment \\
\hline Ralston EL, et al.374 & 1971 & Case series & IV & 1 & 12 & Surgery \\
\hline Eidelman M, et al. 375 & 2004 & Case series & IV & 1 & 12 & Conservative \\
\hline Tudisco C t al.376 & 2012 & Case series & IV & 1 & 36 & Surgery - Bunnell open \\
\hline Vasileff WK, et al. ${ }^{377}$ & 2014 & Case series & IV & 1 & 8 & Surgery -Bunnell open \\
\hline
\end{tabular}


Emanuela Marsilio, Simone Natali, Leonardo Pellicciari, Luca Perazzo, Eleonora Piccirilli, Clelia Rugiero, Antonio Vadalà, Manuela Verri.

\section{Ethics}

The Authors declare that this research was conducted following basic ethical aspects and international standards as required by the journal and recently update $\mathrm{in}^{378}$.

\section{References}

1. Maffulli N, Waterston SW, Squair J, Reaper J, Douglas AS. Changing incidence of Achilles tendon rupture in Scotland: a 15-year study. Clin J Sport Med. 1999 Jul;9(3):157-160.

2. Longo UG, Petrillo S, Maffulli N, Denaro V. Acute Achilles tendon rupture in athletes. Foot Ankle Clin. 2013 Jun;18(2):319338.

3. Egger AC, Berkowitz MJ. Achilles tendon injuries. Curr Rev Musculoskelet Med. 2017;10:72-80.

4. Vosseller JT, Ellis SJ, Levine DS, Kennedy JG, Elliott AJ, Deland JT, Roberts MM, O'Malley MJ. Achilles tendon rupture in women. Foot Ankle Int. 2013 Jan;34(1):49-53.

5. Maffulli N, Giai Via A, Oliva F. Chronic Achilles Tendon Rupture. Open Orthop J. 2017 Jul 31;11:660-669.

6. Jean-Luc Besse. IFFAS Symposium 3, September. 2014

7. Nilsson-Helander K, Silbernagel KG, Thomee R, Faxen E, Olsson N, Eriksson BL. Acute Achilles tendon rupture. A randomized, controlled study comparing surgical and nonsurgical treatments using validated outcome measures. Am J Sports Med. 2010;38:2186-2193.

8. Hunt KJ, Bundy AM, Maffulli N, Schuberth JM. Achilles tendon ruptures. Foot\&Ankle Specialist. 2014 June;7(3).

9. Józsa L, Kvist M, Balint BJ, et al. The role of recreational sport activity in Achilles tendon rupture. A clinical, pathoanatomical, and sociological study of 292 cases. Am J Sports Med. 1989;17(3):338- 343.

10. Kannus $P$, Natri A. Aetiology and pathophysiology of tendon ruptures in sports. Scand J Med Sci Sports. 1997;7(2):107112.

11. Laseter JT, Russell JA. Anabolic steroid-induced tendon pathology: a review of the literature. Med Sci Sports Exerc. 1991;23:1-3.

12. Khaliq $Y$, Zhanel GG. Fluoroquinolone-associated tendinopathy: a critical review of the literature. Clin Infect Dis. 2003;36(11):1404-1410.

13. Parmar C, Meda KP. Achilles tendon rupture associated with combination therapy of levofloxacin and steroid in four patients and a review of the literature. Foot Ankle Int. 2007;28:12871289.

14. Wertz J, Galli M, Borchers JR. Achilles Tendon Rupture: Risk Assessment for Aerial and Ground Athletes. Sports Health. 2012;5(5)

15. Magnusson SP, Qvortup K, Larsen JO, et al. Collagen fibril size and crimp morphology in ruptured and intact Achilles tendons. Matrix Biol. 2002;21(4):369-377.

16. McCarthy MM, Hannafin JA. The Mature Athlete: Aging Tendon and Ligament. SPORTS HEALTH. 2014 Jan-Feb;6(1).

17. Claessen FMAP, de Vos RG, Reijman M, Meuffels DE. Predictors of Primary Achilles Tendon Ruptures. Sports Med.
2014;44:1241-1259.

18. Smith FB, Smith BA. Musculoskeletal differences between males and female. Sports Med Arth Rev. 2002;10:98-100.

19. Frizziero A, Vittadini F, Gasparre G, Masiero S. Impact of oestrogen deficinecy and aging on tendon: concise review. MLTJ 2014;4(3):324-328.

20. Lemoine JK, Lee JT, Trappe TA. Impact of sex and chronic resistance training on human patellar tendon dry mass, collagen content, and collagen cross-linking. Am J Physiol Regul Integr Comp Physiol. 2009;296:119-124.

21. Cook JL, Khan KM, Kiss ZS, Griffiths L. Patellar tendinosis in junior basketball players: a controlled clinical and ultrasonographic study of 268 tendons in players aged 14-18 years. Scand J Med Sci Sports. 2000;10(4):216-230.

22. Józsa L, Balint JB, Kannus P, et al. Distribution of blood groups in patients with tendon rupture. An analysis of 832 cases. $J$ Bone Joint Surg Br. 1989;71(2):272-274.

23. Kujala UM, Järvinen $M$, Natri $A$, et al. $A B O$ blood groups and musculoskeletal injuries. Injury. 1992;23(2):131-133.

24. Oliva F, Piccirilli E, Berardi AC, et al. Hormones and tendinopathies: the current evidence. Br Med Bull. 2016:1-20.

25. Battery L, Maffulli N. Inflammation in Overuse Tendon Injuries. Sports Med Arthrosc Rev. 2011;19:13-217.

26. Hast MW, Abboud JA, Soslowsky LJ. Exploring the role of hypercolesterolemia in tendon health and repair. MLTJ. 2014 4:275-279.

27. Dogan A, Korkmaz M, Cengiz N, Kalender AM, Gokalp MA Biomechanical comparison of Achilles tenotomy and achilloplasty techniques in young rats: an experimental study. J Am Podiatr Med Assoc. 2009 May-Jun;99(3):216-222.

28. Lusardi DA, Cain JE Jr. The effect of fibrin sealant on the strength of tendon repair of full thickness tendon lacerations in the rabbit Achilles tendon. J Foot Ankle Surg. 1994 SepOct:33(5):443-447.

29. Jielile J, Asilehan B, Wupuer A, et al. Early Ankle Mobilization Promotes Healing in a Rabbit Model of Achilles Tendon Rupture. Orthopedics. 2016 Jan-Feb;39(1):e117-126.

30. Aydın BK, Altan E, Acar MA, Erkoçak ÖF, Ugraş S. Effect of Ankaferd blood stopper ${ }^{\circledR}$ on tendon healing: an experimental study in a rat model of Achilles tendon injury. Eklem Hastalik Cerrahisi. 2015;26(1):31-37.

31. Dabak TK, Sertkaya O, Acar N, Donmez BO, Ustunel I. The Effect of Phospholipids (Surfactant) on Adhesion and Biomechanical Properties of Tendon: A Rat Achilles Tendon Repair Model. Biomed Res Int. 2015;2015:689314.

32. Aliodoust M, Bayat M, Jalili MR, et al. Evaluating the effect of low-level laser therapy on healing of tentomized Achilles tendon in streptozotocin-induced diabetic rats by light microscopical and gene expression examinations. Lasers Med Sci. 2014 Jul;29(4):1495-1503.

33. Gereli A, Akgün U, Uslu S, Ağır I, Ateş F, Nalbantoğlu U. The effect of organic silicon injection on Achilles tendon healing in rats. Acta Orthop Traumatol Turc. 2014;48(3):346-354.

34. Liang JI, Lin PC, Chen MY, Hsieh TH, Chen JJ, Yeh ML. The effect of tenocyte/hyaluronic acid therapy on the early recovery of healing Achilles tendon in rats. J Mater Sci Mater Med. 2014 Jan;25(1):217-227.

35. Selek O, Buluç L, Muezzinoğlu 3, Ergün RE, Ayhan S, Karaöz E. Mesenchymal stem cell application improves tendon healing via anti-apoptotic effect (Animal study). Acta Orthop Traumatol Turc. 2014;48(2):187-195.

36. Zeytin K, Ciloğlu NS, Ateş F, Vardar Aker F, Ercan F. The effects of resveratrol on tendon healing of diabetic rats. Acta Orthop Traumatol Turc. 2014;48(3):355-362.

37. Hapa O, Erduran M, Havitçioğlu H, Çeçen B, Akşahin E, Güler 
S, Atalay K. Strength of different Krackow stitch configurations using high-strength suture. J Foot Ankle Surg. 2013 JulAug;52(4):448-450.

38. Huri G, Biçer ÖS, Ozgözen L, Uçar Y, Garbis NG, Hyun YS. A novel repair method for the treatment of acute Achilles tendon rupture with minimally invasive approach using button implant: a biomechanical study. Foot Ankle Surg. 2013 Dec;19(4):261266.

39. Nouruzian M, Alidoust M, Bayat M, Bayat M, Akbari M. Effect of low-level laser therapy on healing of tenotomized Achilles tendon in streptozotocin-induced diabetic rats. Lasers Med Sci. 2013 Feb;28(2):399-405.

40. Leek BT, Tasto JP, Tibor LM, Healey RM, Freemont A, Linn $\mathrm{MS}$, et al. Augmentation of tendon healing with butyric acid-impregnated sutures: biomechanical evaluation in a rabbit model. Am J Sports Med. 2012 Aug;40(8):1762-1771.

41. Ni T, Senthil-Kumar P, Dubbin K, et al. A photoactivated nanofiber graft material for augmented Achilles tendon repair Lasers Surg Med. 2012 Oct;44(8):645-652.

42. Ishiyama N, Moro T, Ohe T. Reduction of Peritendinous adhesions by hydrogel containing biocompatible phospholipid polymer MPC for tendon repair. J Bone Joint Surg Am. 2011 Jan 19;93(2):142-149.

43. Ishiyama N, Moro T, Ishihara $\mathrm{K}$, et al. The prevention of peritendinous adhesions by a phospholipid polymer hydrogel formed in situ by spontaneous intermolecular interactions. Biomaterials. 2010 May;31(14):4009-4016.

44. Lyras DN, Kazakos K, Georgiadis G, et al. Does a single application of PRP alter the expression of IGF-I in the early phase of tendon healing? J Foot Ankle Surg. 2011 May-Jun;50(3) 276-282.

45. Saygi B, Yildirim Y, Cabukoğlu C, Kara H, Ramadan SS, Esemenli $T$. The effect of dehydration and irrigation on the healing of Achilles tendon: an experimental study. Ulus Travma Acil Cerrahi Derg. 2008 Apr;14(2):103-109.

46. Chong AK, Ang AD, Goh JC, Hui JH, Lim AY, Lee EH, Lim BH. Bone marrow-derived mesenchymal stem cells influence early tendon-healing in a rabbit Achilles tendon model. J Bone Joint Surg Am. 2007 Jan;89(1):74-81.

47. Gilbert TW, Stewart-Akers AM, Simmons-Byrd A, Badylak SF Degradation and remodeling of small intestinal submucosa in canine Achilles tendon repair. J Bone Joint Surg Am. 2007 Mar;89(3):621-630.

48. Duygulu F, Karaoğlu S, Zeybek ND, Kaymaz FF, Güneş T. The effect of subcutaneously injected nicotine on Achilles tendon healing in rabbits. Knee Surg Sports Traumatol Arthrosc. 2006 Aug;14(8):756-761.

49. Strauch B, Patel MK, Rosen DJ, Mahadevia S, Brindzei N, Pilla AA. Pulsed magnetic field therapy increases tensile strength in a rat Achilles' tendon repair model. J Hand Surg Am. 2006 Sep;31(7):1131-1135.

50. Bolt $P$, Clerk AN, Luu HH, et al. BMP-14 gene therapy increases tendon tensile strength in a rat model of Achilles tendon injury. J Bone Joint Surg Am. 2007 Jun;89(6):1315-1320.

51. Zantop T, Gilbert TW, Yoder MC, Badylak SF. Extracellular matrix scaffolds are repopulated by bone marrow derived cells in a mouse model of Achilles tendon reconstruction. J Orthop Res. 2006 Jun;24(6):1299-1309.

52. Chan BP, Amann C, Yaroslavsky AN, et al. Photochemical repair of Achilles tendon rupture in a rat model. J Surg Res. 2005 Apr;124(2):274-279.

53. Kashiwagi K, Mochizuki $Y$, Yasunaga $Y$, Ishida O, Deie $M$, Ochi M. Effects of transforming growth factor-beta 1 on the early stages of healing of the Achilles tendon in a rat model. Scand J Plast Reconstr Surg Hand Surg. 2004:38(4):193-197.
54. Orhan Z, Ozturan K, Guven A, Cam K. The effect of extracorporeal shock waves on a rat model of injury to tendo Achillis. $A$ histological and biomechanical study. J Bone Joint Surg Br. 2004 May;86(4):613-618.

55. Kazimoğlu C, Bölükbaşi $S$, Kanatli $U$, Senköylü A, Altun NS, Babaç $C$, et al. A novel biodegradable PCL film for tendon reconstruction: Achilles tendon defect model in rats. Int J Artif Organs. 2003 Sep;26(9):804-812.

56. Palmes D, Spiegel HU, Schneider TO, Langer M, Stratmann $\mathrm{U}$, Budny $\mathrm{T}$, Probst A. Achilles tendon healing: longterm biomechanical effects of postoperative mobilization and immobilization in a new mouse model. J Orthop Res. 2002 Sep;20(5):939-946.

57. Thermann $\mathrm{H}$, Frerichs $\mathrm{O}$, Holch $\mathrm{M}$, Biewener A. Healing of Achilles tendon, an experimental study: part 2- Histological, immunohistological and ultrasonographic analysis. Foot Ankle Int. 2002 Jul;23(7):606-613.

58. Rickert M, Jung M, Adiyaman M, Richter W, Simank HG. A growth and differentiation factor-5 (GDF-5)-coated suture stimulates tendon healing in an Achilles tendon model in rats. Growth Factors. 2001;19(2):115-126.

59. Pneumaticos SG, Phd PCN, McGarvey WC, Mody DR, Trevino SG. The effects of early mobilization in the healing of Achilles tendon repair. Foot Ankle Int. $2000 \mathrm{Jul} ; 21$ (7):551-557.

60. Owoeye I, Spielholz NI, Fetto J, Nelson AJ. Low-intensity pulsed galvanic current and the healing of tenotomized rat Achilles tendons: preliminary report using load-to-breaking measurements. Arch Phys Med Rehabil. 1987 Jul;68(7):415418.

61. Petrou CG, Karachalios TS, Khaldi L, Karantanas AH, Lyritis GP. Calcitonin effect on Achilles tendon healing. An experimental study on rabbits. J Musculoskelet Neuronal Interact. 2009 Jul-Sep;9(3):147-154.

62. Fukawa T, Yamaguchi S, Watanabe A, et al. Quantitative Assessment of Tendon Healing by Using MR T2 Mapping in a Rabbit Achilles Tendon Transection Model Treated with Platelet-rich Plasma. Radiology. 2015 Sep;276(3):748-755.

63. Adams SB Jr, Thorpe MA, Parks BG, Aghazarian G, Allen E, Schon LC. Stem cell-bearing suture improves Achilles tendon healing in a rat model. Foot Ankle Int. 2014 Mar;35(3):293299.

64. Irkören S, Demirdöver C, Akad BZ, Aytuğ Z, Yilmaz E, Oztan $Y$. Use of a perichondrial autograft on the peritendinous adhesion: an experimental study in rabbits. Acta Orthop Traumatol Turc. 2012;46(3):208-214.

65. Meimandi-Parizi A, Oryan A, Moshiri A. Role of tissue engineered collagen based tridimensional implant on the healing response of the experimentally induced large Achilles tendon defect model in rabbits: a long term study with high clinical relevance. J Biomed Sci. 2013 May 14;20:28.

66. Oryan A, Moshiri A, Parizi Meimandi A, Silver IA. A long-term in vivo investigation on the effects of xenogenous based, electrospun, collagen implants on the healing of experimentally-induced large tendon defects. J Musculoskelet Neuronal Interact. 2013 Sep;13(3):353-367.

67. Godbout C, Bilodeau R, Bouchard P, Frenette J. Thrombocytopenia alters early but not late repair in a mouse model of Achilles tendon injury. Wound Repair Regen. 2009 MarApr;17(2):260-267.

68. Boyd RPR, Dimock R, Solan MC, Porter E. Achilles tendon rupture: how to avoid missing the diagnosis $\mathrm{Br} J$ Gen Pract. 2015 Dec;65(641):668-669.

69. Maffulli N. The clinical diagnosis of subcutaneous tear of the Achilles tendon. A prospective study in 174 patients. Am $J$ Sports Med. 1998;26(2):266-270. 
70. Van Dijk CN, Karlsson J, Maffulli N, Thermann H. Achilles tendon rupture. Current concepts DJO Publications. 2008;4:2732.

71. Garras DN, Raikin SM, Bhat SB, Taweel N, Karanjia H. MRI is unnecessary for diagnosing acute Achilles tendon ruptures: clinical diagnostic criteria. Clin Orthop Relat Res. 2012 Aug;470(8):2268-2273.

72. Maffulli N. Clinical tests in sports medicine: more on Achilles tendon. Br J Sports Med. 1996;30:250.

73. Matles AL. Rupture of the tendo Achilles: another diagnostic sign. Bull Hosp Joint Dis. 1975;36:48-51.

74. Singh D. Acute Achilles tendon rupture. Br J Sports Med. 2017 Aug;51(15):1158-1160.

75. Lang TR, Cook J, Rio E, Gaida JE. What tendon pathology is seen on imaging in people who have taken fluoroquinolones? A systematic review. Fundam Clin Pharmacol. 2017;31(1):416.

76. Barfod KW, Riecke AF, Boesen A, Hansen P, Maier JF, Døssing $S$, Troelsen A. Validation of a novel ultrasound measurement of Achilles tendon length. Knee Surg Sports Traumatol Arth. 2015;23(11):3398-3406.

77. Pedersen M, Fredberg U, Langberg H. Sonoelastography as a diagnostic tool in the assessment of musculoskeletal alterations: a systematic review. Ultraschall in der Medizin-European Journal of Ultrasound. 2012;33(05):441-446.

78. Fredberg U, Bolvig L, Andersen NT. Prophylactic Training in Asymptomatic Soccer Players With Ultrasonographic Abnormalities in Achilles and Patellar. Tendons Am J Sports Med. 2008 Mar;36(3):451-460.

79. Flavin R, Gibney R, O'Rourke SK. A Clinical Test To Avoid Sural Nerve Injuries In Percutaneous Achilles Tendon Repairs. In Orthopaedic Proceedings. Orthopaedic Proceedings. 2008 Aug;90(SUPP III):493-493.

80. Ofer N, Akselrod S, Nyska M, Werner M, Glaser E, Shabat S. Motion-based tendon diagnosis using sequence processing of ultrasound images. J Orthop Res. 2004;22(6):1296-1302.

81. Bleakney RR, Tallon C, Wong JK, Lim KP, Maffulli N. Longterm ultrasonographic features of the Achilles tendon after rupture. Clin J Sport Med. 2002;12(5):273-278.

82. Cunndne G, Brophy DP, Gibney RG, FitzGerald O. Diagnosis and treatment of heel pain in chronicinflammatory arthritis using ultrasound. In Seminars in arthritis and rheumatism. 1996; 25(6):383-389.

83. Eliasson P, Couppé C, Lonsdale M, Svensson RB, Neergaard $\mathrm{C}, \mathrm{Kjær} \mathrm{M}$, et al. Ruptured human Achilles tendon has elevated metabolic activity up to 1 year after repair. Eur J Nucl Med M Imaging. 2016;43(10): 1868-1877.

84. Jielile J, Badalihan A, Qianman B, Satewalede T, Wuerliebieke J, Kelamu M, Jialihasi A. Clinical outcome of exercise therapy and early post-operative rehabilitation for treatment of neglected Achilles tendon rupture: a randomized study. Knee Surg Sports Traumatol Arth. 2016;24(7): 2148-2155.

85. Busilacchi A, Olivieri M, Ulisse S, Gesuita R, Skrami E, Lording $\mathrm{T}$, et al. Real-time sonoelastography as novel follow-up method in Achilles tendon surgery. Knee Surg Sports Traumatol Arth. 2016;24(7):2124-2132.

86. Chiu CH, Yeh WL, Tsai MC, Chang SS, Hsu KY, Chan YS. Endoscopy-assisted percutaneous repair of acute Achilles tendon tears. Foot \& Ankle International. 2013;34(8):1168-1176.

87. Jielile J, Sabirhazi G, Hu G, Chen J, Aldyarhan K, Zheyiken J, et al. Novel surgical technique and early kinesiotherapy for acute Achilles tendon rupture. Foot \& Ankle International. 2012;33(12):1119-1127.

88. Gigante A, Moschini A, Verdenelli A, Del Torto M, Ulisse S, De
Palma L. Open versus percutaneous repair in the treatment of acute Achilles tendon rupture: a randomized prospective study. Knee Surgery, Sports Traumatol Arthr. 2008;16 (2):204-209.

89. Maffulli N, Tallon C, Wong J, Lim KP, Bleakney R. No adverse effect of early weight bearing following open repair of acute tears of the Achilles tendon. J Sports Med Physical Fitness. 2003a;43(3):367.

90. Costa ML, Shepstone L, Darrah C, Marshall T, Donell ST. Immediate full-weight-bearing mobilisation for repaired Achilles tendon ruptures: a pilot study. Injury. 2003;34(11):874-876.

91. Maffulli N, Tallon C, Wong J, Lim KP, Bleakney R. Early weightbearing and ankle mobilization after open repair of acute midsubstance tears of the Achilles tendon. Am J Sports Med. 2003;31(5):692-700.

92. Möller M, Kälebo P, Tidebrant G, Movin T, Karlsson J. The ultrasonographic appearance of the ruptured Achilles tendon during healing: a longitudinal evaluation of surgical and nonsurgical treatment, with comparisons to MRI appearance. Knee Surg Sports Traumatol Arthr. 2002;10(1):49-56.

93. Bullock MJ, Mourelatos J, Mar A. Achilles Impingement Tendinopathy on Magnetic Resonance Imaging. J Foot Ankle Surg. 2017;56(3):555-563.

94. Aguila Maldonado R, Ruta S, Valuntas ML, García M. Ultrasonography assessment of heel entheses in patients with spondyloarthritis: a comparative study with magnetic resonance imaging and conventional radiography. Clin Rheumatol. 2017;36(8):1811-1817.

95. Stoller DW. Magnetic Resonance Imaging in Orthopaedics and Sports Medicine. 2007:2336.

96. Berquist. MRI of the Musculoskeletal System. 2012.

97. Rosenberg ZS, Beltran J, Bencardino JT. From the RSNA Refresher Courses. Radiological Society of North America. MR imaging of the ankle and foot. Radiographics. 2000;20 Spec No:S153-179.

98. Neumayer F, Mouhsine E, Arlettaz Y, Gremion G, Wettstein M, Crevoisier $\mathrm{X}$. A new conservative-dynamic treatment for the acute ruptured Achilles tendon. Arch Orthop Trauma Surg. 2010;130(3):363-368.

99. Metz R, Verleisdonk EJ, van der Heijden GJ, et al. Acute Achilles tendon rupture: minimally invasive surgery versus nonoperative treatment with immediate full weightbearing. A randomized controlled trial. Am J Sports Med. 2008;36(9): 1688-1694.

100. Willits $\mathrm{K}$, Amendola $A$, Bryant $\mathrm{D}$, et al. Operative versus nonoperative treatment of acute Achilles tendon ruptures: a multicenter randomized trial using accelerated functional rehabilitation. J Bone Joint Surg Am. 2010;92(17):2767-2775.

101. Soroceanu A, Sidhwa F, Aarabi S, Kaufman A, Glazebrook M. Surgical versus nonsurgical treatment of acute Achilles tendon rupture: a meta-analysis of randomized trials. J Bone Joint Surg Am. 2012;94(23):2136-2143.

102. Wilkins R, Bisson LJ. Operative versus nonoperative management of acute Achilles tendon ruptures: a quantitative systematic review of randomized controlled trials. Am J Sports Med. 2012;40:2154-2160.

103. Olsson N, Silbernagel KG, Eriksson BI, et al. Stable surgical repair with accelerated rehabilitation versus nonsurgical treatment for acute Achilles tendon ruptures: a randomized controlled study. Am J Sports Med. 2013;41:2867-2876.

104. Kaniki N, Willits K, Mohtadi N, et al. A Retrospective Comparative Study With Historical Control to Determine the Effectiveness of Platelet-Rich Plasma as Part of Nonoperative Treatment of Acute Achilles Tendon Rupture. Arthroscopy. 2014; 30(9):1139-1145. 
105. Mark-Christensen T, Troelsen A, Kallemose T, Barfod KW Functional rehabilitation of patients with acute Achilles tendon rupture: a meta-analysis of current evidence. Knee Surg Sports Traumatol Arthrosc. 2014.

106. Young SW, Patel A, Zhu M, et al. Weight-bearing in the nonoperative treatment of acute Achilles tendon ruptures: a randomized controlled trial. J Bone Joint Surg Am. 2014;96:10731079.

107. Zhang $\mathrm{H}$, Tang $\mathrm{H}, \mathrm{He} Q$, et al. Surgical versus conservative intervention for acute Achilles tendon rupture: a PRISMA-Compliant systematic review of overlapping meta-analyses. Medicine. 2015;94(45):1-7.

108. Lantto I, Heikkinen J, Flinkkila T, et al. Epidemiology of Achilles tendon ruptures: increasing incidence over a 33-year period. Scand J Med Sci Sports. 2015;25:133-138.

109. Khan RJ, Carey Smith RL. Surgical interventions for treating acute Achilles tendon ruptures. Cochrane Database Syst Rev. 2010 Sep 8;(9):CD003674.

110. Aviña Valencia JA, Guillen Alcala MA. Repair of acute Achilles tendon rupture. Comparative study of two surgical techniques. Acta Ortop Mex. 2009;23(3):125-129.

111. Kou J. AAOS Clinical Practice Guideline: acute Achilles tendon rupture. J Am Acad Orthop Surg. 2010 Aug;18(8):511513.

112. Jiang N, Wang B, Chen A, Dong F, Yu B. Operative versus nonoperative treatment for acute Achilles tendon rupture: a meta-analysis based on current evidence. Int Orthop. 2012 Apr;36(4):765-773.

113. Jones MP, Khan RJ, Carey Smith RL. Surgical interventions for treating acute Achilles tendon rupture: key findings from a recent cochrane review. J Bone Joint Surg Am. 2012 Jun. 20;94(12):e88.

114. Wu Y, Lin L, Li H, Zhao Y, Liu L, Jia Z, et al. Is surgical intervention more effective than non-surgical treatment for acute Achilles tendonrupture? A systematic review of overlapping meta-analyses. Int J Surg. 2016 Dec;36(Pt A):305-311.

115. Miyamoto W, Imade S, Innami K, Kawano H, Takao M. Acute Achilles Tendon Rupture Treated by Double Side-Locking Loop Suture Technique With Early Rehabilitation. Foot Ankle Int. 2017 Feb;38(2):167-173.

116. Yang B, Liu Y, Kan S, Zhang D, Xu H, Liu F, Ning G, Feng S. Outcomes and complications of percutaneous versus open repair of acute Achilles tendonrupture: A meta-analysis. Int $J$ Surg. 2017 Apr;40:178-186.

117. Del Buono A, Volpin A, Maffulli N. Minimally invasive versus open surgery for acute Achilles tendon rupture: a systematic review. Br Med Bull. 2014;109:45-54.

118. Li CG, Li B, Yang YF. Management of acute Achilles tendon rupture with tendon-bundle technique. J Int Med Res. 2017 Feb;45(1):310-319.

119. Lewis N, Quitkin HM. Strength analysis and comparison of the Teno Fix Tendon Repair System with the two-strand modified Kessler repair in the Achilles tendon. Foot Ankle Int. 2003 Nov;24(11):857-860.

120. Manent A, Lopez L, Vilanova J, Mota T, Alvarez J, Santamaría A, Oliva XM. Assessment of the Resistance of Several Suture Techniques in Human Cadaver AchillesTendons. J Foot Ankle Surg. 2017 Sep-Oct;56(5):954-959.

121. Aktas S, Kocaoglu B, Nalbantoglu U, Seyhan M, Guven O. End-to-end versus augmented repair in the treatment of acute Achilles tendon ruptures. J Foot Ankle Surg. 2007 SepOct;46(5):336-340.

122. Ozer H, Selek HY, Harput G, Oznur A, Baltaci G. Achilles Tendon Open Repair Augmented With Distal Turndown Tendon Flap and Posterior Crural Fasciotomy. J Foot Ankle Surg.
2016 Nov-Dec;55(6):1180-1184.

123. Kocaoglu B, Ulku TK, Gereli A, et al. Evaluation of absorbable and non absorbable sutures for repair of Achilles tendon rupture with a suture-guiding device. Foot Ankle Int. 2015 Jun;36(6):691-695.

124. Kara A, Celik H, Seker A, et al. Granuloma formation secondary to Achilles tendon repair with non absorbable suture. Int J Surg Case Rep. 2014;5:720-722.

125. Ollivere BJ, Bosman HA, Bearcroft PW, Robinson AH. Foreign body granulomatous reaction associated with polyethelene "Fiberwire $\left({ }^{\circledR}\right)$ " suture material used in Achilles tendon repair. Foot Ankle Surg. 2014 Jun;20(2):e27-29.

126. Baig MN, Yousaf I, Galbraith JG, Din R. Absorbable Polydioxanone (PDS) suture provides fewer wound complications than polyester (ethibond) suture in acute Tendo-Achilles rupture repair. Ir Med J. 2017 May 10;110(5):566.

127. Sadoghi P, Rosso C, Valderrabano V, et al. Initial Achilles tendon repair strength-synthesized biomechanical data from 196 cadaver repairs. Int Orthop (SICOT). 2012;36:1947-1951.

128. Herbort M, Haber A, Zantop T, et al. Biomechanical comparison of the primary stability of suturing Achilles tendon rupture: a cadaver study of Bunnell and Kessler techniques under cyclic loading conditions. Arch Orthop Trauma Surg. 2008 Nov;128(11):1273-1277.

129. McCoy BW, Haddad SL. The strength of Achilles tendon repair: a comparison of three suture techniques in human cadaver tendons. Foot Ankle Int. 2010 Aug;31(8):701-705.

130. Sánchez M, Anitua E, Azofra J, et al. Comparison of surgically repaired Achilles tendon tears using platelet-rich fibrin matrices. Am J Sports Med. 2007;35(2):245-251.

131. Schepull T, Kvist J, Norrman H, et al. Autologous platelets have no effect on the healing of human Achilles tendon ruptures: a randomized single-blind study. Am J Sports Med. 2011;39(1):38-47.

132. De Carli A, Lanzetti RM, Ciompi A, et al. Can platelet-rich plasma have a role in Achilles tendon surgical repair? Knee Surg Sports Traumatol Arthrosc. 2016;24(7):2231-2237.

133. Alvitti $F$, Gurzì M, Santilli V, Paoloni M, Padua R, Bernetti A, et al. Achilles Tendon Open Surgical Treatment With PlateletRich Fibrin Matrix Augmentation: Biomechanical Evaluation. J Foot Ankle Surg. 2017;56:581-585.

134. Zou J, Mo X, Shi Z, Li T, Xue J, Mei G, Li X. A Prospective Study of Platelet-Rich Plasma as Biological Augmentation for Acute Achilles Tendon Rupture Repair. Biomed Res Int. 2017;2016:9364170.

135. Keating JF, Will EM. Operative versus non-operative treatment of acute rupture of tendo Achillis. J Bone Joint Surg Br. 2011 Aug;93(8):1071-1078.

136. Nistor L. Surgical and non-surgical treatment of Achilles Tendon rupture. A prospective randomized study. J Bone Joint Surg Am. 1981 Mar;63(3):394-399.

137. Cetti R, Christensen SE, Ejsted R, Jensen NM, Jorgensen U. Operative versus nonoperative treatment of Achilles tendon rupture. A prospective randomized study and review of the literature. Am J Sports Med. 1993 Nov-Dec;21(6):791-799.

138. Möller M, Movin T, Granhed H, Lind K, Faxén E, Karlsson J. Acute rupture of tendon Achillis. A prospective randomised study of comparison between surgical and non-surgical treatment. J Bone Joint Surg Br. 2001;Aug;83(6):843-848 .

139. Twaddle BC, Poon P. Early motion for Achilles tendon ruptures: is surgery important? A randomized, prospective study. Am J Sports Med. 2007 Dec;35(12):2033-2038.

140. Kolodziej L, Bohatyrewicz A, Kromuszczyska J, et al. Efficacy and Complications of Open and Minimally Invasive Surgery in Acute Achilles Tendon Rupture: a Prospective Randomised 
Clinical Study and preliminary Report. Int Orthop. 2013 Apr;37(4):625-629.

141. Cretnik A, Kosanovic M, Smrkolj V. Percutaneous versus open repair of the ruptured Achilles tendon: a comparative study. Am J Sports Med. 2005;33(9):1369-1379.

142. Aktas S, Kocaoglu B. Open versus minimal invasive repair with Achillon device. Foot Ankle Int. 2009 May;30(5):391-397.

143. Karabinas PK, Benetos IS, Lampropoulou-Adamidou K, et al. Percutaneous versus Open Repair of Acute Achilles Tendon Ruptures. Eur J Orthop Surg Traumatol. 2014 May;24(4):607613.

144. Lim J, Dalal R, Waseem M. Percutaneous vs Open Repair of the Ruptured Achilles Tendonea Prospective Randomized Controlled Study. Foot Ankle Int. 2001 Jul;22(7):559-568.

145. Henriquez H, Munoz R, Carcuro G, et al. Is percutaneous repair better than open repair in acute Achilles tendon rupture? Clin Orthop Relat Res 470. 2012. 998e1003.

146. Carmont MR, Heaver C, Pradhan A, Mei-Dan O, Gravare Silbernagel K. Surgical repair of the ruptured Achilles tendon: the cost-effectiveness of open versus percutaneous repair. Knee Surg Sports Traumatol Arthrosc. 2013 Jun;21(6):1361-1368.

147. Miller D, Waterston S, Reaper J, et al. Conservative management, percutaneous or open repair of acute Achilles tendon rupture: a retrospective study. Scott Med J. 2005 Nov;50 (4):160-165.

148. Chan AP, Chan YY, Fong DT, Wong PY, Lam HY, Lo CK, et al. Clinical and biomechanical outcome of minimal invasive and open repair of the Achilles tendon. Sports Med Arthrosc Rehabil Ther Technol. 2011 Dec. 20;3(1):32.

149. Goren D, Ayalon M, Nyska M. Isokinetic strength and endurance after percutaneous and open surgical repair of Achilles tendon ruptures. Foot Ankle Int. 2005 Apr;26(4):286290.

150. Daghino W, Enrietti E, Sprio AE, di Prun NB, Berta GN, Massè A. Subcutaneous Achilles tendon rupture: A comparison between open technique and mini-invasive tenorrhaphy with Achillon ${ }^{\circledR}$ suture system. Injury. 2016 Nov;47(11):2591-2595.

151. Haji A, Sahai A, Symes A, Vyas JK. Percutaneous versus open tendon Achillis repair. Foot Ankle Int. 2004 Apr;25 (4):215-218.

152. Zhao HM, Yu GR, Yang YF, Zhou JQ, Aubeeluck A. Outcomes and complications of operative versus non-operative treatment of acute Achilles tendon rupture: a meta-analysis. Chin Med J (Engl). 2011 Dec;124(23):4050-4055.

153. Rebeccato A, Santini S, Salmaso G, Nogarin L. Repair of the Achilles tendon rupture: a functional comparison of three surgical techniques. J Foot Ankle Surg. 2001 Jul-Aug;40(4):188194.

154. De Carli A, Vadalà A, Ciardini R, lorio R, Ferretti A. Spontaneous Achilles tendon ruptures treated with a mini-open technique: clinical and functional evaluation. J Sports Med Phys Fitness. 2009 Sep;49(3):292-296.

155. Ng ES, Ng YO, Gupta R, Lim F, Mah E. Repair of acute Achilles tendon rupture using a double-ended needle. J Orthop Surg (Hong Kong). 2006 Aug;14(2):142-146.

156. Bhattacharyya $M$, Gerber $B$. Mini-invasive surgical repair of the Achilles tendon-does it reduce post-operative morbidity? Int Orthop. 2009 Feb;33(1):151-156.

157. Mukundan C, El Husseiny M, Rayan F, Salim J, Budgen A. "Mini-open" repair of acute tendo Achilles ruptures-the solution? Foot Ankle Surg. 2010 Sep;16(3):122-125.

158. Vadalà $A$, De Carli $A$, Vulpiani $M C$, lorio $R$, Vetrano $M$, Scapellato S, Suarez T, Di Salvo F, Ferretti A. Clinical, functional and radiological results of Achilles tenorrhaphy surgically treated with mini-open technique. J Sports Med Phys Fitness. 2012
Dec.

159. Vadalà A, Lanzetti RM, Ciompi A, Rossi C, Lupariello D, Ferretti $A$. Functional evaluation of professional athletes treated with a mini-open technique for Achilles tendon rupture. MLTJ. 2014 Jul 14;4(2):177-181.

160. Keller A, Ortiz C, Wagner E, Wagner P, Mococain P. Mini-open tenorrhaphy ofacute Achilles tendon ruptures: medium-term follow-up of 100 cases. Am J Sports Med. 2014 Mar;42 (3):731-736.

161. Klein EE, Weil L Jr, Baker JR, Weil LS Sr, Sung W, Knight J. Retrospective analysis of mini-open repair versus open repair for acute Achilles tendon ruptures Foot Ankle Spec. 2013 Feb;6(1):15-20.

162. Bartel AF, Elliott AD, Roukis TS. Incidence of complications after Achillon $\circledast$ mini-open suture system for repair of acute midsubstance Achilles tendonruptures: a systematic review. J Foot Ankle Surg. 2014 Nov-Dec;53(6):744-746.

163. Taşatan E, Emre TY, Demircioğlu DT, Demiralp B, Kırdemir V. Long Term Results of Mini-Open Repair Technique in the Treatment of Acute Achilles Tendon Rupture: A Prospective Study. J Foot Ankle Surg. 2016 Sep-Oct;55(5):971-975.

164. Jallageas R, Bordesa J, Daviet JC, Mabitc C, Costec C. Evaluation of surgical treatment for ruptured Achilles tendon in 31 athletes. OrthopTraumatol: Sur Res. 2013;99:577-584.

165. Zayni R, Coursier R, Zakaria M, Desrousseaux JF, Cordonnier D, Polveche G. Activity level recovery after acute Achilles tendon rupture surgically repaired: a series of 29 patients with a mean follow-up of 46 months. MLTJ. 2017;7:69-77.

166. Taglialavoro G, Biz C, Mastrangelo G, Aldegheri R. The repair of the Achilles tendon rupture: comparison of two percutaneous techniques. Strat Traum Limb Recon. 2011;6:147-154.

167. Bradley JP, Tibone JE. Percutaneous and open surgical repairs of Achilles tendon ruptures. A comparative study. Am J Sports Med. 1990;18:188-195.

168. Tenenbaum S, Dreiangel N, Segal A, Herman A, Israeli A, Chechik $A$. The percutaneous surgical approach for repairing acute Achilles tendon rupture: a comprehensive outcome assessment. J Am Podiatr Med Assoc. 2010;100:270-275.

169. Maes R, Copin G, Averous C. Is percutaneous repair of the Achilles tendon a safe technique? A study of 124 cases. Acta Orthop Belg. 2006;72:179-183.

170. Lacoste S, Férona JM, Cherriera B. Percutaneous Tenolig ${ }^{\circledR}$ repair under intra-operative ultrasonography guidance in acute Achilles tendon rupture. Orthop Traumatol Sur Res. 2014;100:925-930.

171. Maffulli $N$ and Leadbetter WB. Free gracilis tendon graft in neglected tears of the Achilles tendon. Clin J Sport Med. 2005 Mar;15(2):56-61.

172. El Shewy MT, El Barbary HM, Abdel-Ghani H. Repair of chronic rupture of the Achilles tendon using 2 intratendinous flaps from the proximal gastrocnemius-soleus complex. Am J Sports Med. 2009 Aug;37(8):1570-1577.

173. Maffulli N, Spiezia F, Longo UG, Denaro V. Less-invasive reconstruction of chronic Achilles tendon ruptures using a peroneus brevis tendon transfer. Am J Sports Med. 2010 Nov;38(11):2304-2312.

174. Us AK, Bilgin SS, Aydin T, Mergen E. Repair of neglected Achilles tendon ruptures: procedures and functional results. Arch Orthop Trauma Surg. 1997;116(6-7):408-411.

175. Kissel CG, Blacklidge DK, Crowley DL. Repair of neglected Achilles tendon ruptures: procedure and functional results. $J$ Foot Ankle Surg. 1994 Jan-Feb;33(1):46-52.

176. Esenyel CZ, Tekin C, Cakar M, et al. Surgical treatment of the neglected Achilles tendon rupture with Hyalonect. J Am Podiatr Med Assoc. 2014 Sep-Oct;104(5):434-443. 
177. Guclu B, Basat HC, Yildirim T, Bozduman O, Us AK. Longterm Results of Chronic Achilles Tendon Ruptures Repaired With V-Y Tendon Plasty and Fascia Turndown. Foot Ankle Int. 2016 Jul;37(7):737-742.

178. Rush JH. Operative repair of neglected rupture of the tendo Achillis. Aust N Z J Surg. 1980 Aug;50(4):420-422.

179. Wapner KL, Pavlock GS, Hecht PJ, Naselli F, Walther R. Repair of chronic Achilles tendon rupture with flexor hallucis longus tendon transfer. Foot Ankle. 1993 Oct;14(8):443-449.

180. Pintore E, Barra V, Pintore R, Maffulli N. Peroneus brevis tendon transfer in neglected tears of the Achilles tendon. J Trauma. 2001 Jan;50(1):71-78.

181. Ademoğlu Y, Ozerkan F, Ada S, Bora A, Kaplan I, Kayalar M, Kul F. Reconstruction of skin and tendon defects from wound complications after Achilles tendon rupture. J Foot Ankle Surg. 2001 May-Jun;40(3):158-165.

182. Wong MW, Ng VW. Modified flexor hallucis longus transfer for Achilles insertional rupture in elderly patients. Clin Orthop Relat Res. 2005 Feb;(431):201-206.

183. Elias I, Besser M, Nazarian LN, Raikin SM. Reconstruction for missed or neglected Achilles tendon rupture with $\mathrm{V}-\mathrm{Y}$ lengthening and flexor hallucis longus tendon transfer through one incision. Foot Ankle Int. 2007 Dec;28(12):1238-1248.

184. Mahajan RH, Dalal RB. Flexor hallucis longus tendon transfer for reconstruction of chronically ruptured Achilles tendons. J Orthop Surg (Hong Kong). 2009 Aug;17(2):194-198.

185. Maffulli N, Spiezia F, Pintore E, Longo UG, Testa V, Capasso G, Denaro V. Peroneus brevis tendon transfer for reconstruction of chronic tears of the Achilles tendon: a long-term followup study. J Bone Joint Surg Am. 2012 May 16;94(10):901-905.

186. Rahm S, Spross C, Gerber F, Farshad M, Buck FM, Espinosa $\mathrm{N}$. Operative treatment of chronic irreparable Achilles tendon ruptures with large flexor hallucis longus tendon transfers. Foot Ankle Int. 2013 Aug;34(8):1100-1110.

187. Dumbre Patil SS, Dumbre Patil VS, Basa VR, Dombale AB. Semitendinosus Tendon Autograft for Reconstruction of Large Defects in Chronic Achilles Tendon Ruptures. Foot Ankle Int 2014 Jul;35(7):699-705

188. Singh A, Nag K, Roy SP, Gupta RC, Gulati V, Agrawal N. Repair of Achilles tendon ruptures with peroneus brevis tendon augmentation. J Orthop Surg (Hong Kong). 2014 Apr;22 (1):52-55.

189. Khiami F, Di Schino M, Sariali E, Cao D, Rolland E, Catonné Y. Treatment of chronic Achilles tendon rupture by shortening suture and free sural triceps aponeurosis graft. Orthop Traumatol Surg Res. 2013 Sep;99(5):585-591.

190. Maffulli N, Oliva F, Costa V, Del Buono A. The management of chronic rupture of the Achilles tendon: minimally invasive peroneus brevis tendon transfer. Bone Joint J. 2015 Mar;97$B(3): 353-357$.

191. Ahmad J, Jones K, Raikin SM. Treatment of Chronic Achilles Tendon Ruptures With Large Defects. Foot Ankle Spec. 2016 Oct;9(5):400-408.

192. Gedam PN, Rushnaiwala FM. Endoscopy-Assisted Achilles Tendon Reconstruction With a Central Turndown Flap and Semitendinosus Augmentation. Foot Ankle Int. 2016 Dec;37( 12):1333-1342. Epub. 2016 Sep. 20.

193. Maffulli N, Loppini M, Longo UG, Maffulli GD, Denaro V. Minimally invasive reconstruction of chronic Achilles tendon ruptures using the ipsilateral free semitendinosus tendon graft and interference screw fixation. Am J Sports Med. 2013 May;41(5):1100-1107.

194. Mann RA, Holmes GB Jr, Seale KS, Collins DN. Chronic rupture of the Achilles tendon: a new technique of repair. J Bone Joint Surg Am. 1991 Feb;73(2):214-219.
195. Elgohary HEA, Elmoghazy NA, Abd Ellatif MS. Combined flexor hallucis longus tendon transfer and gastrocnemius recession for reconstruction of gapped chronic Achilles tendon ruptures. Injury. 2016 Dec;47(12):2833-2837. Doi: 10.1016/j.injury.2016.10.029. Epub. 2016 Nov 3.

196. Miao X, Wu Y, Tao H, Yang D, Huang L. Reconstruction of Kuwada grade IV chronic Achilles tendon rupture by minimally invasive technique. Indian J Orthop. 2016 Sep;50(5):523-528.

197. Maffulli N, Oliva F, Del Buono A, Florio A, Maffulli G. Surgical management of Achilles tendon re-ruptures: a prospective cohort study. Int Orthop. 2015 Apr;39(4):707-714.

198. Yeoman TF, Brown MJ, Pillai A. Early post-operative results of neglected tendo-Achilles rupture reconstruction using short flexor hallucis longus tendon transfer: a prospective review. Foot (Edinb). 2012 Sep;22(3):219-223..

199. Park YS, Sung KS. Surgical reconstruction of chronic Achilles tendon ruptures using various methods. Orthopedics. 2012 Feb 17;35(2):e213-218.200. Sarzaeem MM, Lemraski MM, Safdari F. Chronic Achilles tendon rupture reconstruction using a free semitendinosus tendon graft transfer. Knee Surg Sports Traumatol Arthrosc. 2012 Jul;20(7):1386-1391.

201. Zheng L, Zhang XS, Dong ZG, Liu LH, Wei JW. One-staged reconstruction of Achilles tendon and overlying skin defects with suppuration: using peroneus brevis tendon transfer and reversed sural neurofasciocutaneous flap. Arch Orthop Trauma Surg. 2011 Sep;131(9):1267-1272.

202. Wegrzyn J, Luciani JF, Philippot R, Brunet-Guedj E, Moyen B, Besse JL. Chronic Achilles tendon rupture reconstruction using a modified flexor hallucis longus transfer. Int Orthop. 2010 Dec;34(8):1187-1192.

203. Lee KB, Park YH, Yoon TR, Chung JY. Reconstruction of neglected Achilles tendon rupture using the flexor hallucis tendon. Knee Surg Sports Traumatol Arthrosc. 2009 Mar;17(3):316-320.

204. Fotiadis E, Chatzisimeon A, Samoladas E, Antonarakos P, Akritopoulos P, Akritopoulou K. A Combined Repair Technique for Early Neglected Achilles Tendon Ruptures. Eur J Trauma Emerg Surg. 2008 Feb;34(1):37-42.

205. Lui TH. Endoscopic assisted flexor hallucis tendon transfer in the management of chronic rupture of Achilles tendon. Knee Surg Sports Traumatol Arthrosc. 2007 Sep;15(9):1163-1166. Epub. 2007 May 30.

206. Miskulin M, Miskulin A, Klobucar H, Kuvalja S. Neglected rupture of the Achilles tendon treated with peroneus brevis transfer: a functional assessment of 5 cases. J Foot Ankle Surg 2005 Jan-Feb;44(1):49-56.

207. Dalal RB, Zenios M. The flexor hallucis longus tendon transfer for chronic tendo-Achilles ruptures revisited. Ann R Coll Surg Engl. 2003 Jul;85(4):283.

208. Seker A, Kara A, Armagan R, Oc Y, Varol A, Sezer HB. Reconstruction of neglected Achilles tendon ruptures with gastrocnemius flaps: excellent results in long-term follow-up. Arch Orthop Trauma Surg. 2016 Oct;136(10):1417-1423.

209. Lapidus LJ, Ray BA, Hamberg P. Medial Achilles tendon island flap: a novel technique to treat reruptures and neglected ruptures of the Achilles tendon. Int Orthop. 2012 Aug;36 (8):1629-1634

210. Takao M, Ochi M, Naito K, Uchio Y, Matsusaki M, Oae K. Repair of neglected Achilles tendon rupture using gastrocnemius fascial flaps. Arch Orthop Trauma Surg. 2003 Nov;123(9):471 474. Epub. 2002 Oct 25.

211. Ozan F, Dogar F, Gurbuz K, Ekinci Y, Koyuncu S, Sekban H. Chronic Achilles Tendon Rupture Reconstruction Using the Lindholm Method and the Vulpius Method. J Clin Med Res. 2017 Jul:9(7):573-578. 
212. Sanada T, Uchiyama E. Gravity Equinus Position to Control the Tendon Length of Reversed Free Tendon Flap Reconstruction for Chronic Achilles Tendon Rupture. J Foot Ankle Surg. 2017 Jan-Feb;56(1):37-41

213. Maffulli N, Del Buono A, Loppini M, Denaro V. Ipsilateral free semitendinosus tendon graft with interference screw fixation for minimally invasive reconstruction of chronic tears of the Achilles tendon. Oper Orthop Traumatol. 2014 Oct;26(5):513519.

214. El Shazly O, Abou El Soud MM, El Mikkawy DM, El Ganzoury I, Ibrahim AM. Endoscopic-assisted Achilles tendon reconstruction with free hamstring tendon autograft for chronic rupture of Achilles tendon: clinical and isokinetic evaluation. Arthroscopy. 2014 May;30(5):622-628.

215. Tay D, Lin HA, Tan BS, Chong KW, Rikhraj IS. Chronic Achilles tendon rupture treated with two turndown flaps and flexor hallucis longus augmentation: two-year clinical outcome. Ann Acad Med Singapore. 2010 Jan;39(1):58-60.

216. Nilsson-Helander K, Swärd L, Silbernagel KG, Thomeé R, Eriksson BI, Karlsson J. A new surgical method to treat chronic ruptures and reruptures of the Achilles tendon. Knee Surg Sports Traumatol Arthrosc. 2008 Jun;16(6):614-620.

217. Tawari AA, Dhamangaonkar AA, Goregaonkar AB, Chhapan JB. Augmented repair of degenerative tears of tendo Achilles using peroneus brevis tendon: early results. Malays Orthop J. 2013 Mar;7(1):19-24.

218. Oksanen MM, Haapasalo HH, Elo PP, Laine HJ. Hypertrophy of the flexor hallucis longus muscle after tendon transfer in patients with chronic Achilles tendon rupture. Foot Ankle Surg. 2014 Dec;20(4):253-257.

219. Zappia M, Berritto D, Oliva F, et al. High resolution real time ultrasonography of the sural nerve after percutaneous repair of the Achilles tendon. Foot Ankle Surg. 2017;37:636-643.

220. Cohen M. US imaging in operated tendons. J Ultrasound. 2012;15:69-75. Doi: 10.1016/j.jus.2011.11.001.

221. Zappia M, Cuomo G, Martino MT, et al. The effect of foot position on Power Doppler Ultrasound grading of Achilles enthesitis. Rheumatol Int. 2016;36:871-874.

222. Fornage BD. Achilles tendon: US examination. Radiology. 1986;159:759-764.

223. Blei CL, Nirschl RP, Grant EG. Achilles tendon: US diagnosis of pathologic conditions. Work in progress. Radiology. 1986;159:765-767.

224. Rupp S, Tempelhof S, Fritsch E. Ultrasound of the Achilles tendon after surgical repair: morphology and function. $\mathrm{Br} J$ Radiol. 1995;68:454-458.

225. Möller M, Kälebo P, Tidebrant G, et al. The ultrasonographic appearance of the ruptured Achilles tendon during healing: a longitudinal evaluation of surgical and nonsurgical treatment, with comparisons to MRI appearance. Knee Surg Sports Traumatol Arthrosc. 2002;10:49-56.

226. Gitto S, Draghi AG, Bortolotto C, Draghi F. Sonography of the Achilles Tendon After Complete Rupture Repair: What the Radiologist Should Know. J Ultrasound Med. 2016. 35:25292536. D

227. Diao Z-B, Chu H-K, Li N, et al. [Short-term clinical effects of Achillon in repair of acute Achilles tendon rupture]. Zhongguo Gu Shang. 2012;25:959-961.

228. Klein EE, Weil L, Baker JR, et al. Retrospective Analysis of Mini-Open Repair Versus Open Repair for Acute Achilles Tendon Ruptures. Foot Ankle Spec. 2013;6:15-20.

229. Chun KA, Cho K-H. Postoperative ultrasonography of the musculoskeletal system. Ultrason (Seoul, Korea). 2015;34 195-205.
230. Zhang L, Wan W, Wang Y, et al. Evaluation of Elastic Stiffness in Healing Achilles Tendon After Surgical Repair of a Tendon Rupture Using In vivo Ultrasound Shear Wave Elastography. Med Sci Monit. 2016;22:1186-1191. .

231. Tan S, Kudaş S, Özcan AŞ, et al. Real-time sonoelastography of the Achilles tendon: pattern description in healthy subjects and patients with surgically repaired complete ruptures. Skeletal Radiol. 2012;41:1067-1072..

232. Shalabi A, Kristoffersen-Wiberg M, Aspelin P, Movin T. MR evaluation of chronic Achilles tendinosis. A longitudinal study of 15 patients preoperatively and two years postoperatively. Acta Radiol. 2001;42:269-276.

233. Fujikawa A, Kyoto $Y$, Kawaguchi M, et al. Achilles tendon after percutaneous surgical repair: serial MRI observation of uncomplicated healing. AJR Am J Roentgenol. 2007;189:11691174.

234. Karjalainen PT, Aronen HJ, Pihlajamäki HK, et al. Magnetic Resonance Imaging During Healing of Surgically Repaired Achilles Tendon Ruptures. Am J Sports Med. 1997;25:164171.

235. Hahn F, Meyer P, Maiwald C, et al. Treatment of Chronic Achilles Tendinopathy and Ruptures with Flexor Hallucis Tendon Transfer: Clinical Outcome and MRI Findings. Foot Ankle Int. 2008;29:794-802.

236. Sölveborn S-A, Moberg A. Immediate Free Ankle Motion After Surgical Repair of Acute Achilles Tendon Ruptures. Am J Sports Med. 1994;22:607-610.

237. Karjalainen PT, Ahovuo J, Pihlajamäki HK, et al. Postoperative MR Imaging and Ultrasonography of Surgically Repaired Achilles Tendon Ruptures. Acta radiol. 1996;37:639-646.

238. Sarman H, Atmaca H, Cakir O, et al. Assessment of Postoperative Tendon Quality in Patients With Achilles Tendon Rupture Using Diffusion Tensor Imaging and Tendon Fiber Tracking. J Foot Ankle Surg. 2015;54:782-786.

239. Valkering KP, Aufwerber S, Ranuccio F, Lunini E, Edman G, Ackermann PW. Functional weight-bearing mobilization after Achilles tendon rupture enhances early healing response: a single-blinded randomized controlled trial. Knee Surg Sports Traumatol Arthrosc. 2017 Jun;25(6):1807-1816

240. Lantto I, Heikkinen J, Flinkkila T, Ohtonen P, Kangas J, Siira P, Leppilahti J. Early functional treatment versus cast immobilization in tension after Achilles rupture repair: results of a prospective randomized trial with 10 or more years of follow-up. Am J Sports Med. 2015 Sep;43(9):2302-2309.

241. Suchak AA, Bostick GP, Beaupré LA, Durand DC, Jomha NM. The influence of early weight-bearing compared with nonweight-bearing after surgical repair of the Achilles tendon. $J$ Bone Joint Surg Am. 2008 Sep;90(9):1876-1883.

242. Costa ML, MacMillan K, Halliday D, Chester R, Shepstone L, Robinson AH, Donell ST. Randomised controlled trials of immediate weight-bearing mobilization for rupture of the tendo Achillis. J Bone Joint Surg Br. 2006 Jan;88(1):69-77.

243. Kangas J, Pajala A, Siira P, Hämäläinen M, Leppilahti J. Early functional treatment versus early immobilization in tension of the musculotendinous unit after Achilles rupture repair: a prospective, randomized, clinical study. J Trauma. 2003 Jun;54(6):1171-1180.

244. Kerkhoffs GM, Struijs PA, Raaymakers EL, Marti RK. Functional treatment after surgical repair of acute Achilles tendon rupture: wrap vs walking cast. Arch Orthop Trauma Surg. 2002 Mar;122(2):102-105

245. Mortensen HM, Skov O, Jensen PE. Early motion of the ankle after operative treatment of a rupture of the Achilles tendon. A prospective, randomized clinical and radiographic study. $J$ 
Bone Joint Surg Am. 1999 Jul;81(7):983-990.

246. De la Fuente C, Peña y Lillo R, Carreño G, Marambio H. Prospective randomized clinical trial of aggressive rehabilitation after acute Achilles tendon ruptures repaired with Dresden technique. Foot (Edinb). 2016 Mar;26:15-22.

247. Groetelaers RP, Janssen L, van der Velden J, Wieland AW, Amendt AG, Geelen PH, Janzing HM. Functional Treatment or Cast Immobilization After Minimally Invasive Repair of an Acute Achilles Tendon Rupture: Prospective, Randomized Trial. Foot Ankle Int. 2014 Aug;35(8):771-778.

248. Majewski M, Schaeren S, Kohlhaas U, Ochsner PE. Postoperative rehabilitation after percutaneous Achilles tendon repair: early functional therapy versus cast immobilization. Disabil Rehabil. 2008;30(20-22):1726-1732.

249. Kader D, Mosconi M, Benazzo F, Maffulli N. Achilles Tendo Rupture. Tendon Injuries. 2005:187-200.

250. Sharma P, Maffulli N. Biology of tendon injury: healing, modeling and remodeling. J Musculoskelet Neuronal Interact. 2006; 6:181-190.

251. Kannus $P$, Jozsa, L, Jarvinnen M. Basic science of tendons. In: Garrett WJ, Speer K, Kirkendall DT (eds). Principles and Practice of Orthopaedic Sports Medicine. Lippincott Williams \& Wilkins, Philadelphia. 2000:21-37.

252. Williams JG. Achilles tendon lesions in sport. Sports Med. 1986;3:114-135

253. Maffulli N, Moller HD, Evans $\mathrm{CH}$. Tendon healing: can it be optimized? Br J Sports Med. 2002;36:315-16.

254. Oakes BW. Tissue healing and repair: tendons and ligaments. In: Frontera WR (ed). Rehabilitation of Sports Injuries: Scientific Basis. Blackwell Science, Oxford. 2003:56-98.

255. Tillman LJ, Chasan NP. Properties of dense connective tissue and wound healing. In: Hertling D, Kessler RM (eds). Management of Common Musculoskeletal Disorders. Lippincott, Philadelphia. 1996:8-21.

256. Hooley CJ, Cohen RE. A model for the creep behavior of tendon. Int J Biol Macromol. 1979;1:123-132.

257. Abrahamsson SO. Matrix metabolism and healing in the flexor tendon. Experimental studies on rabbit tendon. Scand J Plast Reconstr Surg Hand Surg Suppl. 1991;23:1-51.

258. Amiel D, Akeson W, Harwood FL, Frank CB. Stress deprivation effect on metabolic turnover of medial collateral ligament collagen. Clin Orthop. 1987;172:25-27.

259. Enwemeka CS. Functional loading augments the initial tensile strength and energy absorption capacity of regenerating rabbit Achilles tendons. Am J Phys Med Rehabil. 1992;71:31-38.

260. Kannus P, Jozsa L, Natri A, Jarvinen M. Effects of training, immobilization and remobilization on tendons. Scand J Med Sci Sports. 1997;7:67-71.

261. Bring DK, Reno C, Renstrom P, Salo P, Hart DA, Ackermann $P W$. Joint immobilization reduces the expression of sensory neuropeptide receptors and impairs healing after tendon rupture in a rat model. J Orthop Res. 2009;27:274-280.

262. Maffulli N, King JB. Effects of physical activity on some components of the skeletal system. Sports Med 1992;13:393-407.

263. Akeson WH, Amiel D, Mechanic GL, Woo SL, Harwood FL, Hamer ML. Collagen cross-linking alterations in joint contractures: changes in the reducible cross-links in periarticular connective tissue collagen after nine weeks of immobilization. Connect Tissue Res. 1977;5:15-19.

264. Maganaris CN, Reeves ND, Rittweger J, Sargeant AJ, Jones DA, Gerrits K, DeHaan A. Adaptive response of human tendon to paralysis. Muscle Nerve. 2006;33:85-92.

265. Chiodo CP, Glazebrook M, Bluman EM, et al. Diagnosis and treatment of acute Achilles tendon rupture. J Am Acad Orthop Surg. 2010;18:503-510.
266. Jones MP, Khan R, Smith R. Surgical Interventions for treating acute Achilles tendon rupture: key findings from a recent Cochrane review. J Bone Joint Surg. 2012;94:881-886.

267. Suchak AA, Spooner C, Reid DC, Jomha NM. Postoperative rehabilitation protocols for Achilles tendon ruptures: a metaanalysis. Clin Orthop Relat Res. 2006;445:216-221.

268. Saleh M, Marshall PD, Senior R, MacFarlane A. The Sheffield splint for controlled early mobilisation after rupture of the calcaneal tendon. A prospective, randomised comparison with plaster treatment. J Bone Joint Surg Br. 1992;74:206-209.

269. Petersen OF, Nielsen MB, Jensen KH, Solgaard S. Randomized comparison of CAM walker and light-weight plaster cast in the treatment of first-time Achilles tendon rupture. Ugeskr Laeger. 2002;164:3852-3855.

270. Hutchison AM, Topliss C, Beard D, Evans RM, Williams P. The Treatment of a rupture of the Achilles tendon using a dedicated management programme. Bone Joint J. 2015 Apr;97B(4):510-515.

271. Barfod KW, Brencke J, Lauridsen HB, Ban I, Ebskov L, Troelsen A. Nonoperative dynamic treatment of acute Achilles tendon rupture: the influence of early weight-bearing on clinical outcome: a blinded, randomized controlled trial. J Bone Joint Surg Am. 2014;96:1497-1503.

272. Calder JD, Saxby TS. Early, active rehabilitation following mini-open repair of Achilles tendon rupture: a prospective study. Br J Sports Med. 2005 Nov;39(11):857-859.

273. Bossi P. Conoscere le apparecchiature elettromedicali. McGraw-Hill Education (1/11/2004) ISBN-10: 8838616531 ISBN13: 978-8838616532, Italian. 2004.

274. Notarnicola A, Pesce V, Vicenti G, Tafuri S, Forcignano M, Moretti B. SWAAT study: extracorporeal shock wave therapy and arginine supplementation and other nutraceuticals for insertional Achilles tendinopathy. Advances in Therapy. 2012; 29(9):799-814.

275. Balius R, Álvarez G, Baró F, Jiménez F, Pedret C, Costa E, Martínez-Puig D. A 3-Arm Randomized Trial for Achilles Tendinopathy: Eccentric Training, Eccentric Training Plus a Dietary Supplement Containing Mucopolysaccharides, or Passive Stretching Plus a Dietary Supplement Containing Mucopolysaccharides. CurrTher Res- Clin Exp 2016;78:1-7.

276. Hai Binh B, Ramirez P, Martinez-Puig D. A randomized, placebo-controlled study to evaluate efficacy and safety of a dietary supplement containing mucopolysaccharides, collagen type I and vitamin $\mathrm{C}$ for management of different tendinopathies. Ann Rheum Dis. 2014;73.

277. Nadal F, Bové T, Sanchís D, Martinez-Puig D. 473 Effectiveness of treatment of tendinitis and plantar fasciitis by tendoactive $^{\mathrm{TM}}$. Osteoarthritis and Cartilage. 2009;17:S253.

278. Arquer A, García M, Laucirica JA, et al. The efficacy and safety of oral mucopolysaccharide, type I collagen and vitamin C treatment in tendinopathy patients. Apunts Medicina de l'Esport. 2014;49(182):31-36.

279. Mavrogenis S, Johannessen E, Jensen P, Sindberg C. The effect of essential fatty acids and antioxidants combined with physiotherapy treatment in recreational athletes with chronic tendon disorders. A randomised, double-blind, placebo-controlled study. Phys Ther Sport. 2004;5(4):194-199.

280. Ahmad J, Repka M, Raikin SM. Treatment of myotendinous Achilles ruptures. Foot Ankle Int. 2013;34:1074-1078.

281. Al-Mouazzen L, Rajakulendran K, Najefi A, et al. Percutaneous repair followed by accelerated rehabilitation for acute Achilles tendon ruptures. J Orthop Surg (Hong Kong). 2015; 23:352-356.

282. Amin NH, Old AB, Tabb LP, et al. Performance outcomes after repair of complete Achilles tendon ruptures in national basket- 
ball association players. Am J Sports Med. 2013;41:18641868.

283. Amlang MH, Christiani P, Heinz P, et al. Die perkutane Naht der Achillessehne mit dem Dresdner Instrument. Oper Orthop Traumatol. 2006;18:287-299.

284. Ateschrang A, Gratzer C, Weise K. Incidence and effect of calcifications after open-augmented Achilles tendon repair. Arch Orthop Trauma Surg. 2008;128:1087-1092.

285. Bassi JL, Mahindra P. A modified flap technique as an alternate procedure for open Achilles tendon repair (the Bassi method). Oper Orthop Traumatol. 2006;18:171-181.

286. Bevoni R, Angelini A, D'Apote G, et al. Long term results of acute Achilles repair with triple-bundle technique and early rehabilitation protocol. Injury. 2014;45:1268-1274.

287. Bostick GP, Jomha NM, Suchak AA, et al. Factors associated with calf muscle endurance recovery 1 year after Achilles tendon rupture repair. J Orthop Sports Phys Ther. 2010;40:345351.

288. Boyden EM, Kitaoka HB, Cahalan TD, et al. Late versus early repair of Achilles tendon rupture. Clinical and biomechanical evaluation. Clin Orthop Relat Res. 1995;317:150-158.

289. Carmont MR, Grävare Silbernagel K, Brorsson A, et al. The Achilles tendon resting angle as an indirect measure of Achilles tendon length following rupture, repair, and rehabilitation. Asia-Pacific J Sport Med Arthrosc Rehabil Technol. 2015;2:49-55.

290. Ceccarelli F, Berti L, Giuriati L, et al. Percutaneous and minimally invasive techniques of Achilles tendon repair. Clin Orthop Relat Res. 2007;458:188-193.

291. Chandrakant V, Lozano-Calderon S, McWilliam J. Immediate weight bearing after modified percutaneous Achilles tendon repair. Foot Ankle Int. 2012;33:1093-1097.

292. Chen Z, Wei J, Hou Z, et al. Application of internal fixation of steel-wire limited loop in early Achilles tendon rupture. Asian Pac J Trop Med. 2013;6:902-907.

293. Coutts A, MacGregor A, Gibson J, et al. Clinical and functional results of open operative repair for Achilles tendon rupture in a non-specialist surgical unit. J R Coll Surg Edinb. 2002;47:753762.

294. Cretnik A, Frank A. Incidence and outcome of rupture of the Achilles tendon. Wien Klin Wochenschr. 2004;116:33-38.

295. Cretnik A, Kosir R, Kosanović M. Incidence and outcome of operatively treated Achilles tendon rupture in the elderly. Foot Ankle Int. 2010;31:14-18.

296. Demirel M, Turhan E, Dereboy F, et al. Augmented repair of acute tendo Achilles ruptures with gastrosoleus turn down flap. Indian J Orthop. 2011;45:45-52.

297. Doral MN. What is the effect of the early weight-bearing mobilisation without using any support after endoscopy-assisted Achilles tendon repair? Knee Surg Sport Traumatol Arthrosc. 2013;21:1378-1384.

298. Eames MHA, Eames NWA, McCarthy KR, et al. An audit of the combined non-operative and orthotic management of ruptured tendo Achillis. Injury. 1997;28:289-292.

299. Feldbrin Z, Hendel D, Lipkin A, et al. Achilles tendon rupture and our experience with the Achillon device. Isr Med Assoc J. 2010;12:609-612.

300. Fernández-Fairén M, Gimeno C. Augmented repair of Achilles tendon ruptures. Am J Sports Med. 1997;25:177-181.

301. Fortis AP, Dimas A, Lamprakis AA. Repair of Achilles tendon rupture under endoscopic control. Arthrosc J Arthrosc Relat Surg. 2008;24:683-688.

302. Garabito A, Martinez-Miranda J, Sanchez-Sotelo J. Augmented repair of acute Achilles tendon ruptures using gastrocnemius-soleus fascia. Int Orthop. 2005:29:42-46.
303. Garrido IM, Deval JC, Bosch MN, et al. Treatment of acute Achilles tendon ruptures with Achillon device: clinical outcomes and kinetic gait analysis. Foot Ankle Surg. 2010;16: 189-194.

304. Gorschewsky O, Vogel U, Schweizer A, et al. Percutaneous tenodesis of the Achilles tendon. A new surgical method for the treatment of acute Achilles tendon rupture through percutaneous tenodesis. Injury. 1999;30:315-321.

305. Gorschewsky O, Pitzl M, Pütz A, et al. Percutaneous repair of acute Achilles tendon rupture. Foot Ankle Int. 2004;25:219 224.

306. Guillo S, Del Buono A, Dias M, et al. Percutaneous repair of acute ruptures of the tendo Achillis. Surg. 2013;11:14-19.

307. Halasi T, Tállay A, Berkes I. Percutaneous Achilles tendon repair with and without endoscopic control. Knee Surg Sports Traumatol Arthrosc. 2003;11:409-414.

308. Hohendorff B, Siepen W, Spiering L, et al. Long-term results after operatively treated Achilles tendon rupture: fibrin glue versus suture. J Foot Ankle Surg. 2008;47:392-399.

309. Hufner TM, Brandes DB, Thermann $\mathrm{H}$, et al. Long-term results after functional nonoperative treatment of Achilles tendon rupture. Foot Ankle Int. 2006;27:167-171.

310. Jaakkola JI, Beskin JL, Griffith LH, et al. Early ankle motion after triple bundle technique repair vs. casting for acute Achilles tendon rupture. Foot Ankle Int. 2001;22:979-984.

311. Jacob KM, Paterson R. Surgical repair followed by functional rehabilitation for acute and chronic Achilles tendon injuries: excellent functional results, patient satisfaction and no reruptures. ANZ J Surg. 2007;77:287-291.

312. Jennings AG, Sefton GK, Newman RJ. Repair of acute rupture of the Achilles tendon: a new technique using polyester tape without external splintage. Ann R Coll Surg Engl. 2004;86:445448.

313. Josey RA, Marymont J V, Varner KE, et al. Immediate, full weight bearing cast treatment of acute Achilles tendon ruptures: a long-term follow-up study. Foot Ankle Int. 2003;24: 775-779.

314. Jung HG, Lee KB, Cho SG, et al. Outcome of Achilles tendon ruptures treated by a limited open technique. Foot Ankle Int. 2008:29:803-807.

315. Kakiuchi M. A combined open and percutaneous technique for repair of tendo Achillis: comparison with open repair. J Bone Joint Surg Br. 1995;77:60-63.

316. Karkhanis S, Mumtaz H, Kurdy N. Functional management of Achilles tendon rupture: a viable option for non-operative management. Foot Ankle Surg. 2010;16:81-86.

317. Knobe M, Gradl G, Klos K, et al. Is percutaneous suturing superior to open fibrin gluing in acute Achilles tendon rupture? Int Orthop. 2015;39:535-542.

318. Korkmaz M, Erkoc MF, Yolcu S, et al. Weight bearing the same day versus non-weight bearing for 4 weeks in Achilles tendon rupture. J Orthop Sci. 2015;20:513-516.

319. Kraus R, Stahl J-P, Meyer C, et al. Frequency and effects of intratendinous and peritendinous calcifications after open Achilles tendon repair. Foot Ankle Int. 2004;25:827-832.

320. Labib SA, Hoffler CE, Shah JN, et al. The gift box open Achilles tendon repair method: a retrospective clinical series. J Foot Ankle Surg. 2016;55:39-44.

321. Lansdaal JR, Goslings JC, Reichart M, et al. The results of 163 Achilles tendon ruptures treated by a minimally invasive surgical technique and functional after treatment. Injury. 2007;38: 839-844.

322. Lee DK. A preliminary study on the effects of acellular tissue graft augmentation in acute Achilles tendon ruptures. J Foot Ankle Surg. 2008;47:8-12. 
323. Leppilahti J, Forsman K, Puranen J, et al. Outcome and prognostic factors of Achilles rupture repair using a new scoring method. Clin Orthop Relat Res. 1998;346:152-161.

324. Macquet AJ, Christensen RJ, Debenham M, et al. Open repair of the acutely torn Achilles tendon under local anaesthetic. ANZ J Surg. 2011;81:619-623.

325. Maffulli N, Longo UG, Maffulli GD, et al. Achilles tendon ruptures in elite athletes. Foot Ankle Int. 2011;32:9-15.

326. Maffulli N, Longo UG, Ronga $\mathrm{M}$, et al. Favorable outcome of percutaneous repair of Achilles tendon ruptures in the elderly. Clin Orthop Relat Res. 2010;468:1039-1046.

327. Majewski M, Rohrbach M, Czaja S, et al. Avoiding sural nerve injuries during percutaneous Achilles tendon repair. Am J Sports Med. 2006;34:793-798.

328. Mandelbaum BR, Myerson MS, Forster R. Achilles tendon ruptures: a new method of repair, early range of motion, and functional rehabilitation. Am J Sports Med. 1995;23:392-395.

329. Maniscalco P, Bertone C, Bonci E, et al. Titanium anchors for the repair of distal Achilles tendon ruptures: preliminary report of a new surgical technique. J Foot Ankle Surg. 1998;36:96100.

330. Martinelli B. Percutaneous repair of the Achilles tendon in athletes. Bull Hosp Jt Dis. 2000;59:149-152.

331. McComis GP, Nawoczenski DA, DeHaven K. Functional bracing for rupture of the Achilles tendon: clinical results and analysis of ground-reaction forces and temporal data. J Bone $\mathrm{Jt}$ Surg. 1997;29A:1799-1808.

332. Metz R, van der Heijden GJ, Verleisdonk EJ, et al. Effect of complications after minimally invasive surgical repair of acute Achilles tendon ruptures: report on 211 cases. Am J Sports Med. 2011;39:820-824.

333. Mortensen N, Saether J, Steinke M, et al. Separation of tendon ends after Achilles tendon repair: a prospective, randomized, multicenter study. Orthopedics. 1992;15:899-903.

334. Motta P, Errichiello C, Pontini I. Achilles tendon rupture: a new technique for easy surgical repair and immediate movement of the ankle and foot. Am J Sports Med. 1997;25:172-176.

335. Nestorson J, Movin T, Moller M, et al. Function after Achilles tendon rupture in the elderly: 25 patients older than 65 years followed for 3 years. Scand J Med Sci Sports. 2000;71:64-68.

336. Orr J, McCriskin B, Dutton J. Achillon mini-open Achilles tendon repair: early outcomes and return to duty results in U.S. military service members. J Surg Orthop Adv. 2013;22:23-29.

337. Ozsoy M, Cengiz B, Ozsoy A, et al. Minimally invasive Achilles tendon repair: a modification of the Achillon technique. Foot Ankle Int. 2013;34:1683-1688.

338. Pajala A, Kangas J, Siira $P$, et al. Augmented compared with nonaugmented surgical repair of a fresh total Achilles tendon rupture. A prospective randomized study. J Bone Joint Surg Am. 2009;91:1092-100.

339. Parekh SG, Wray WH, Brimmo O, et al. Epidemiology and outcomes of Achilles tendon ruptures in the National Football League. Foot Ankle Spec. 2009;2:283-286.

340. Park HG, Moon DH, Yoon JM. Limited open repair of ruptured Achilles tendons with Bunnel-type sutures. Foot Ankle Int. 2001;22:985-987.

341. Rajasekar K, Gholve P, Faraj A, et al. A subjective outcome analysis of tendo-Achilles rupture. J Foot Ankle Surg. 2005;44: 32-36.

342. Rettig AC, Liotta FJ, Klootwyk TE, et al. Potential risk of rerupture in primary Achilles tendon repair in athletes younger than 30 years of age. Am J Sports Med. 2005;33:119-123.

343. Richardson LC, Reitman R, Wilson M. Achilles tendon ruptures: functional outcome of surgical repair with a "pull-out" wire. Foot Ankle Int. 2003;24:439-443.

344. Schepull T, Kvist J, Andersson C, et al. Mechanical properties during healing of Achilles tendon ruptures to predict final outcome: a pilot Roentgen stereophotogrammetric analysis in 10 patients. BMC Musculoskelet Disord. 2007;8:116

345. Silbernagel KG, Steele R, Manal K. Deficits in heel-rise height and Achilles tendon elongation occur in patients recovering from an Achilles tendon rupture. Am J Sports Med. 2012;40: 1564-1571.

346. Soldatis J, Goodfellow D, Wilber J. End-to-end operative repair of Achilles tendon rupture. Am J Sports Med. 1997;25:90-95.

347. Solveborn S, Moberg A. Immediate free ankle motion after surgical repair of acute Achilles tendon ruptures. Am J Sports Med. 1994;22:607-610.

348. Sorrenti S. Achilles tendon rupture: effect of early mobilization in rehabilitation after surgical repair. Foot Ankle Int. 2006;27: 407-410.

349. Speck M, Klaue K. Early full weightbearing and functional treatment after surgical repair of acute Achilles tendon rupture. Am J Sports Med. 1998;26:789-793.

350. Stein BE, Stroh DA, Schon LC. Outcomes of acute Achilles tendon rupture repair with bone marrow aspirate concentrate augmentation. Int Orthop. 2015;39:901-905.

351. Strauss $E$, Ishak $C$, Jazrawi $L$, et al. Operative treatment of acute Achilles tendon ruptures: an institutional review of clinical outcomes. Injury. 2007;38:832-838.

352. Talbot J, Williams G, Bismil Q, et al. Results of accelerated postoperative rehabilitation using novel 'suture frame' repair of Achilles tendon rupture. J Foot Ankle Surg. 2012;51:147-151.

353. Troop RL, Losse GM, Lane JG, et al. Early motion after repair of Achilles tendon ruptures. Foot Ankle Int. 1995;16:705-709.

354. Uchiyama E, Nomura A, Takeda Y, et al. A modified operation for Achilles tendon ruptures. Am J Sports Med. 2007;35:17391743.

355. Valente M, Crucul M, Alecci V, et al. Minimally invasive repair of acute Achilles tendon rupture with Achillon device. Musculoskelet Surg. 2012;96:35-39.

356. Wagnon R, Akayi M. The Webb-Bannister percutaneous technique for acute Achilles' tendon ruptures: a functional and MR assessment. J Foot Ankle Surg. 2005;44:437-444.

357. Wallace RGH, Heyes GJ, Michael ALR. The non-operative functional management of patients with a rupture of the tendo Achillis leads to low rates of re-rupture. J Bone Joint Surg Br. 2011:93:1362-1366.

358. Wallace RGH, Traynor IER, Kernohan WG, et al. Combined conservative and orthotic management of acute ruptures of the Achilles tendon. J Bone Joint Surg Am. 2004;86-A:11981202.

359. Cappozzo A. The forces and couples in the human trunk during level walking. J Biomech. 1983;16(4):265-277.

360. Hof AL. An explicit expression for the moment in multibody systems. J Biomech. 1992;25(10):1209-1211.

361. Cappozzo A, Felici F, Figura F, Gazzani F. Lumbar spine loading during half-squat exercises. Med Sci Sports Exerc. 1985;17(November):613-620.

362. Kernozek T, Gheidi N, Ragan R. Comparison of estimates of Achilles tendon loading from inverse dynamics and inverse dynamics-based static optimisation during running. J Sports Sci. 2017;35(21):2073-2079.

363. Rajagopal A, Dembia CL, DeMers MS, Delp DD, Hicks JL, Delp SL. Full-Body Musculoskeletal Model for Muscle-Driven Simulation of Human Gait. IEEE Trans Biomed Eng. 2016;63(10):2068-2079.

364. Delp SL, Loan JP, Hoy MG, Zajac FE, Topp EL, Rosen JM. An 
Interactive Graphics-Based Model of the Lower Extremity to Study Orthopaedic Surgical Procedures. IEEE Trans Biomed Eng. 1990;37(8):757-767.

365. Fukashiro S, Komi P V., Järvinen M, Miyashita M. Comparison between the directly measured Achilles tendon force and the tendon force calculated from the ankle joint moment during vertical jumps. Clin Biomech. 1993;8(1):25-30.

366. Robertson G, Caldwell G, Hamill J, Kamen G, Whittlesey S. Research Methods in Biomechanics. Human Kinetics 2004.

367. Camomilla V, Cereatti A, Cutti AG, Fantozzi S, Stagni R, Vannozzi $G$. Methodological factors affecting joint moments estimation in clinical gait analysis: a systematic review. Biomed Eng Online. 2017;16(1):106.

368. Lamberto G, Martelli S, Cappozzo A, Mazzzà C. To what extent is joint and muscle mechanics predicted by musculoskeletal models sensitive to soft tissue artefacts? J Biomech. 2016.

369. Martelli S, Valente G, Viceconti M, Taddei F. Sensitivity of a subject-specific musculoskeletal model to the uncertainties on the joint axes location. Comput Methods Biomech Biomed Engin. 2015;18(14):1555-1563.

370. Bosmans L, Valente G, Wesseling M, et al. Sensitivity of predicted muscle forces during gait to anatomical variability in musculotendon geometry. J Biomech. 2015;48(10):21162123.
371. Lichtwark GA, Wilson AM. In vivo mechanical properties of the human Achilles tendon during one-legged hopping. J Exp Biol. 2005;208(24):4715-4725..

372. Gerus P, Rao G, Berton E. Subject-Specific Tendon-Aponeurosis Definition in Hill-Type Model Predicts Higher Muscle Forces in Dynamic Tasks. PLoS One. 2012;7(8).

373. Franz JR, Thelen DG. Imaging and simulation of Achilles tendon dynamics: Implications for walking performance in the elderly. J Biomech. 2016;49(9):1403-1410.

374. Ralston EL, Schmidt ER Jr. Repair of the ruptured Achilles tendon. J Trauma. 1971;81:1019-1036.

375. Eidelman M, Nachtigal A, Katzman A, Bialik V. Acute rupture of Achilles tendon in a 7-year-old girl. J Pediatr Orthop B. 2004; 13:32-33.

376. Tudisco C, Bisicchia S. Reconstruction of neglected traumatic Achilles tendon rupture in a young girl. J Orthopaed Traumatol. 2012;13:163-166.

377. Vasileff WK, Moutzouros V. Unrecognized pediatric partial Achilles tendon injury followed by traumatic completion: a case report and literature review. J Foot Ankle Surg. 2014;53:485488.

378. Padulo J, Oliva F, Frizziero A, Maffulli N. Muscles, Ligaments and Tendons Journal - Basic principles and recommendations in clinical and field science research: 2016 update. MLTJ. 2016;6(1):1-5. 